\title{
Direct, indirect and longitudinal immunological effects of anti-CD20 mediated B cell depletion in Multiple Sclerosis
}

\author{
INAUGURAL-DISSERTATION \\ zur Erlangung des Doktorgrades \\ der Medizinischen Fakultät der \\ Georg-August-Universität zu Göttingen
}

vorgelegt von

Nitzan Nissimov

aus

Tel-Aviv, Israel

Göttingen 2021 
Dekan:

\section{Betreuungsausschuss}

Betreuer:

Ko-Betreuer:

\section{Prüfungskommission}

Referent:

Ko-Referent/in:

Drittreferent/in:

Datum der mündlichen Prüfung:
Prof. Dr. med. W. Brück

Prof. Dr. med. M. S. Weber

PD Dr. rer. nat. F. Lühder

Prof. Dr. med. M. S. Weber 
Hiermit erkläre ich, die Dissertation mit dem Titel „Direct, indirect and longitudinal immunological effects of anti-CD20 mediated B cell depletion in Multiple Sclerosis“ eigenständig angefertigt und keine anderen als die von mir angegebenen Quellen und Hilfsmittel verwendet zu haben.

Göttingen, den 10.02.2021

Nitzan Nissimov 
Die Daten, auf denen die vorliegende Arbeit basiert, wurden teilweise publiziert:

Nissimov N, Hajiyeva Z, Torke S, Grondey K, Brück W, Häusser-Kinzel S, Weber MS (2020): B cells reappear less mature and more activated after their anti-CD20-mediated depletion in multiple sclerosis. Proc Natl Acad Sci U S A 117, 25690-25699 


\section{Table of contents}

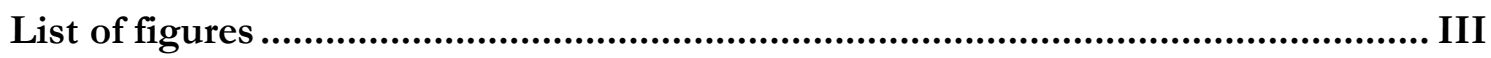

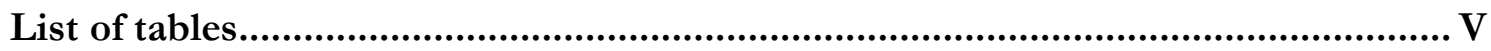

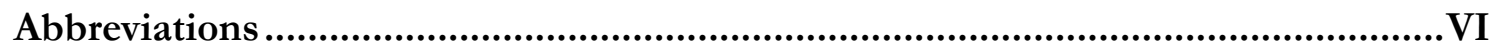

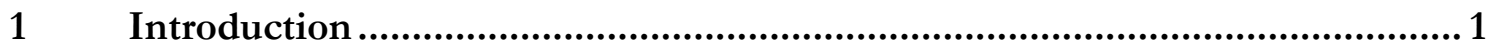

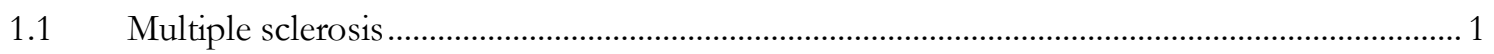

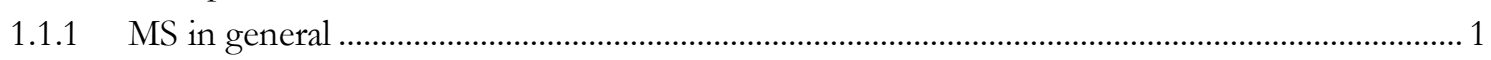

1.1.2 Etiology, pathogenesis, pathophysiology and neuropathology .................................................. 1

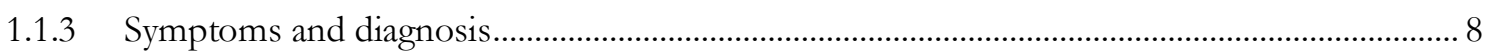

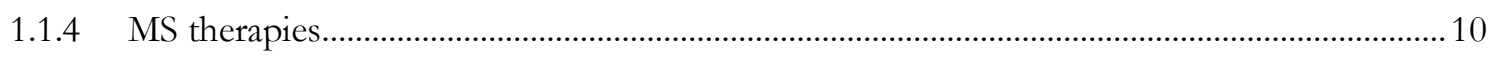

1.2 Anti-CD20 antibodies (Rituximab, Ocrelizumab, Ofatumumab).............................................11

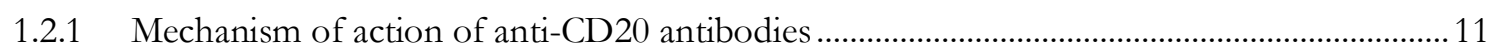

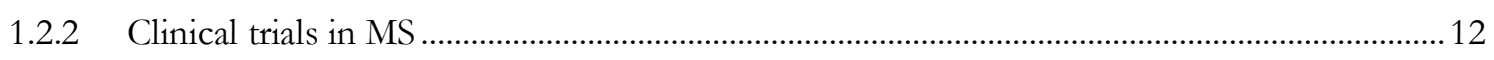

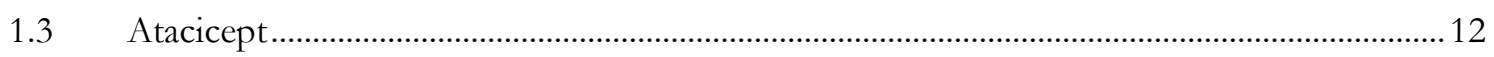

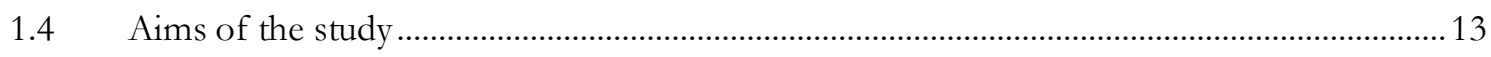

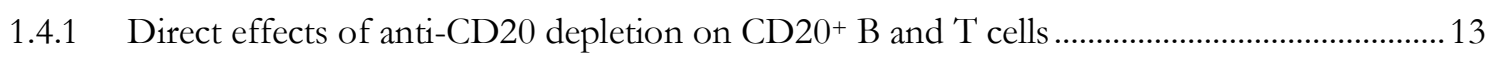

1.4.2 Indirect effects on other immune cell populations...................................................................... 13

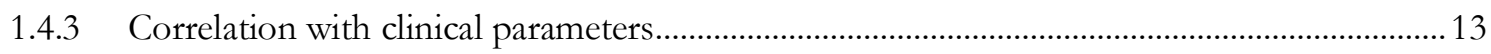

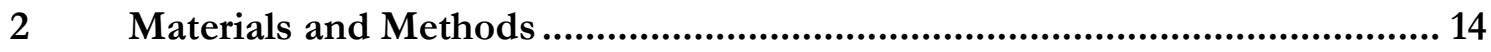

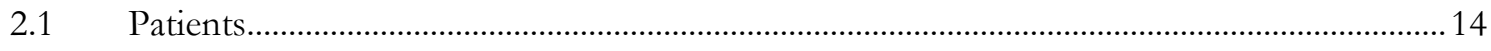

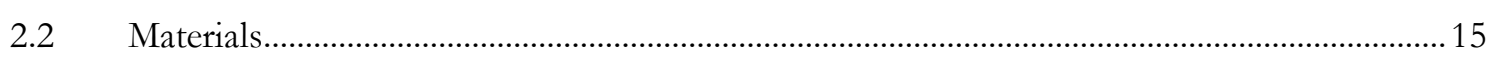

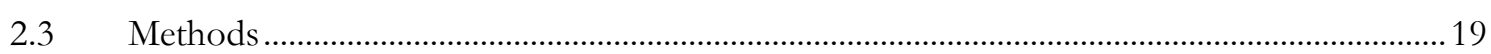

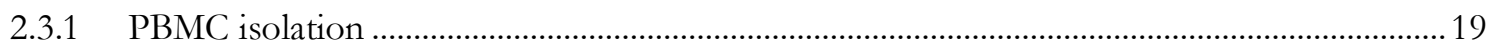

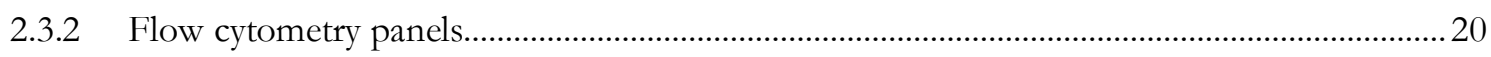

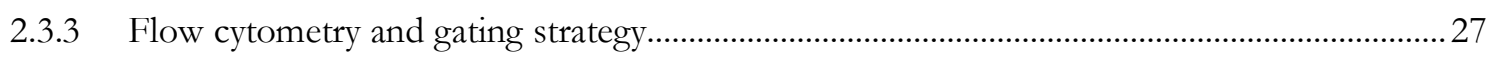

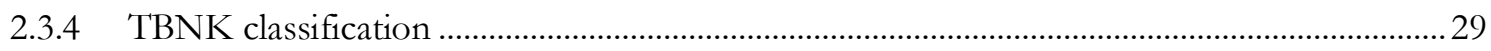

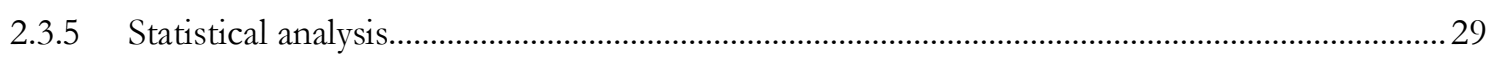

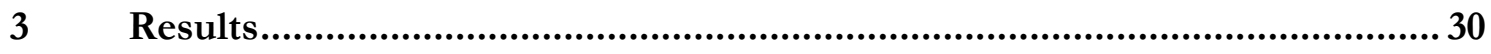

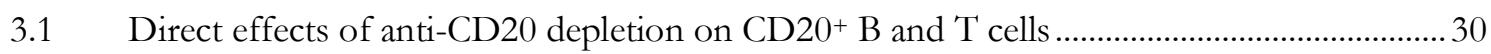

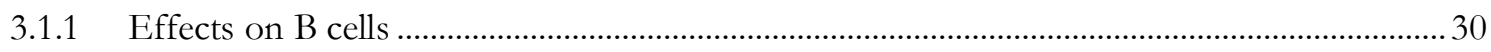

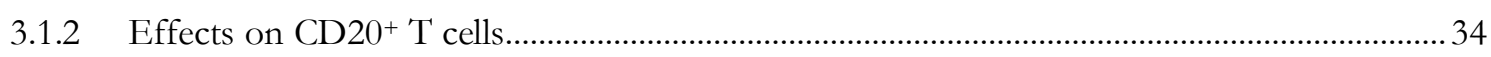

3.2 Indirect effects on other immune cell populations......................................................................

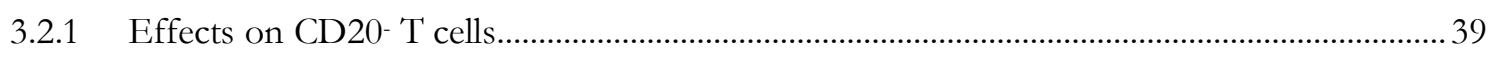

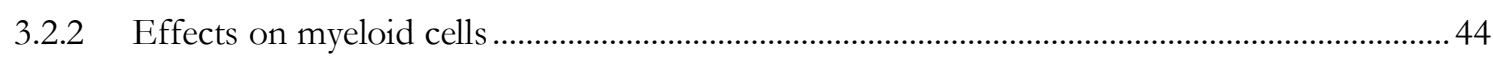

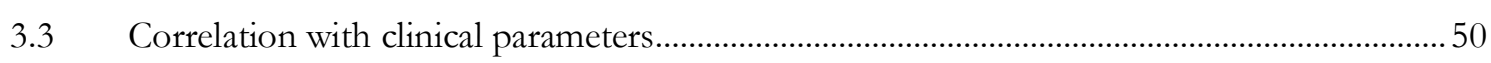

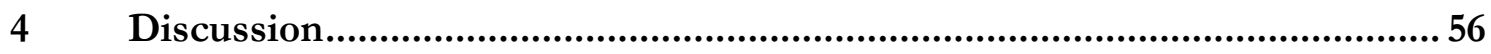

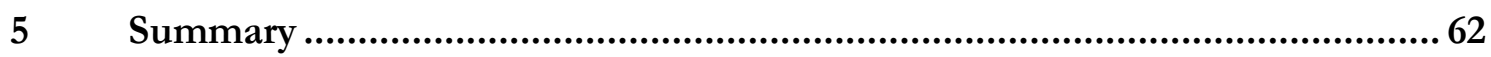




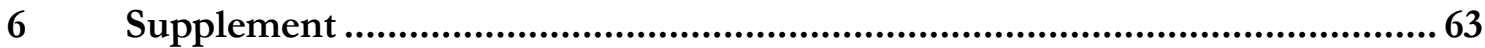

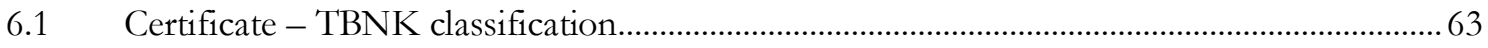

6.2 Correlation between naïve and memory B cell frequencies and age.........................................64

6.3 Data to different B cell activation, APC function and cytokine phenotype among the

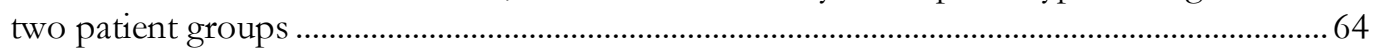

6.4 Data to different cell phenotypes among the two patient groups.............................................66

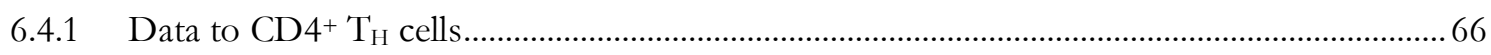

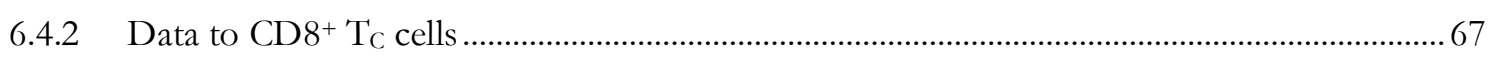

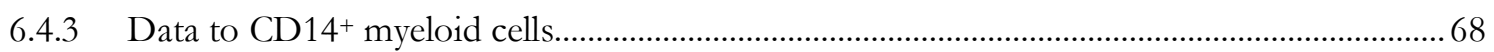

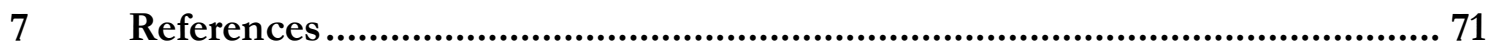




\section{List of figures}

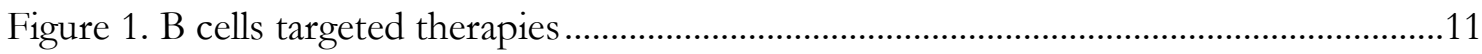

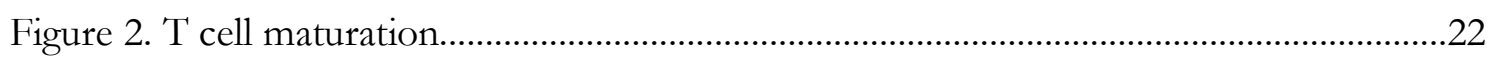

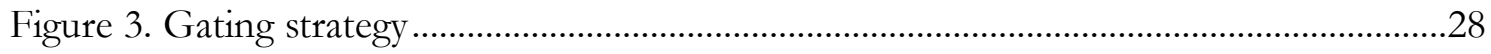

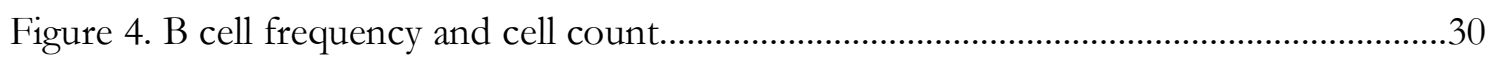

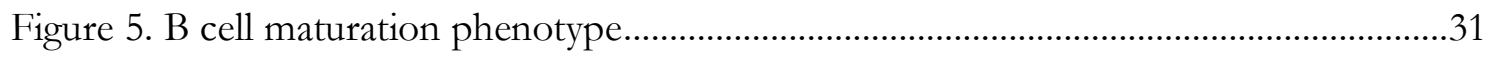

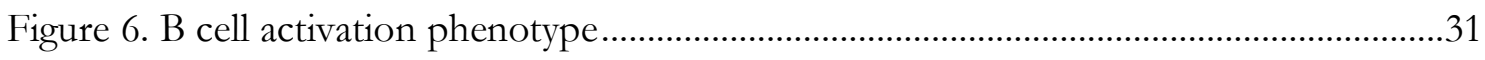

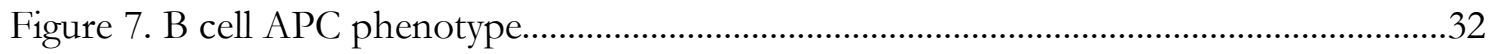

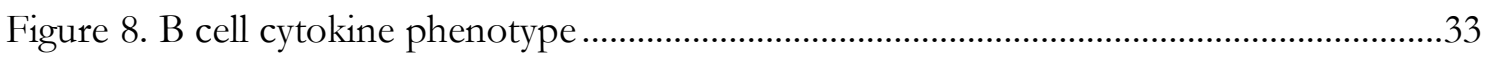

Figure 9. Overview of $\mathrm{CD} 20^{+}$cells population ...........................................................................

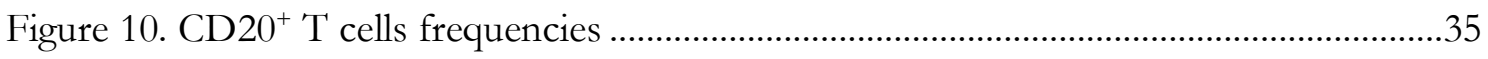

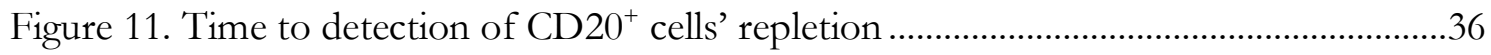

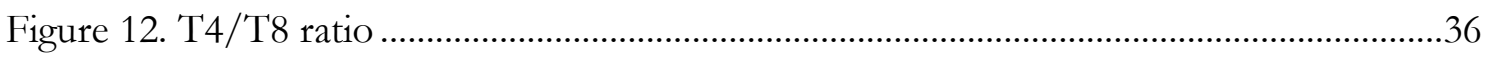

Figure 13. $\mathrm{CD} 20^{+} \mathrm{CD}^{+} \mathrm{T}_{\mathrm{H}}$ cells maturation and $\mathrm{CD} 25$ expression phenotype......................37

Figure 14. $\mathrm{CD} 20^{+} \mathrm{CD}^{+} \mathrm{T}_{\mathrm{C}}$ cells maturation and $\mathrm{CD} 25$ expression phenotype......................38

Figure 15. $\mathrm{CD}^{+} \mathrm{T}_{\mathrm{H}}$ cells frequency and cell count ...................................................................

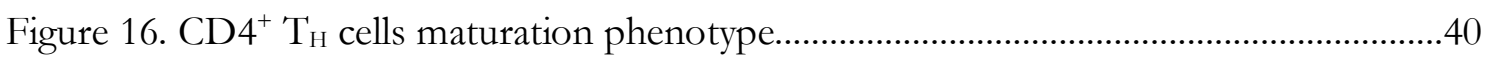

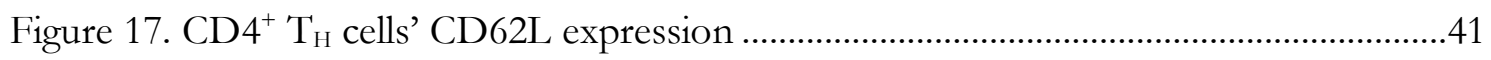

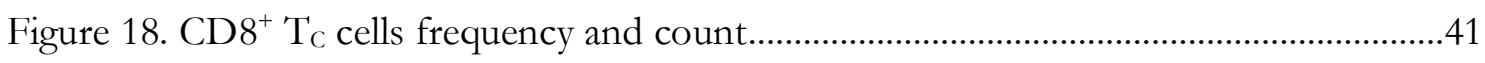

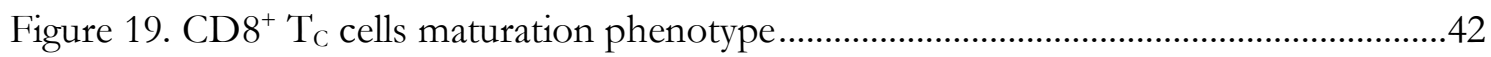

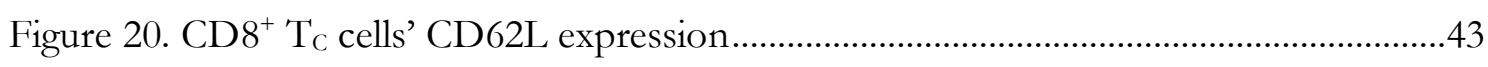

Figure 21. CD14 ${ }^{+}$myeloid cells frequency and monocytes' cell count.....................................44

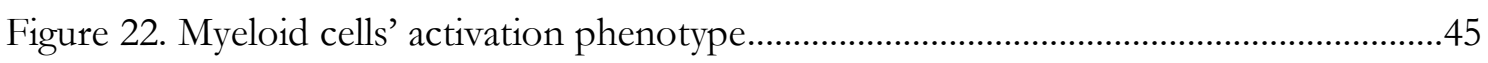

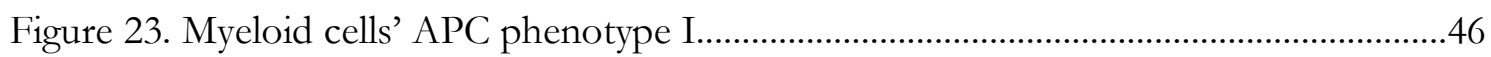

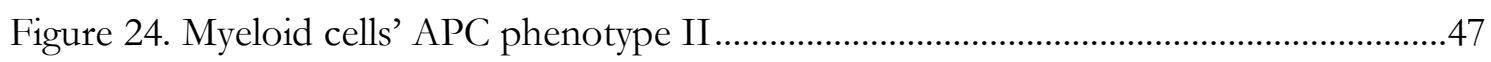

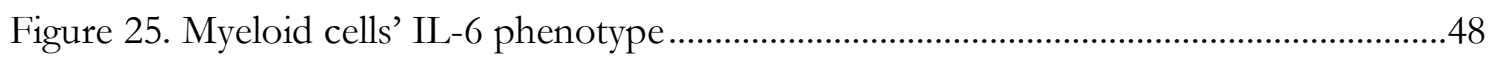

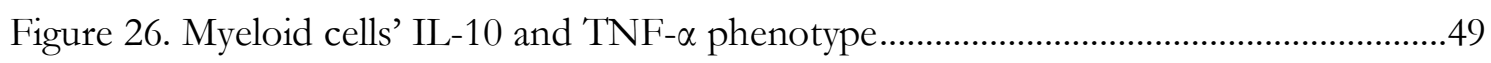

Figure 27. Correlation between B cell frequency/count with age and sex..............................50

Figure 28. Correlation between naïve and memory B cell frequencies with EDSS score......51

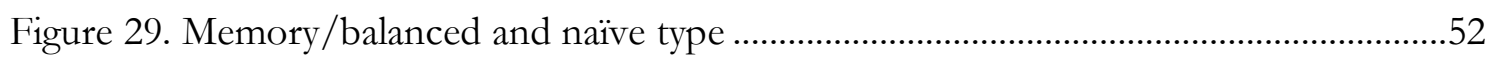

Figure 30. Correlation between the time to detection of $\mathrm{CD} 20^{+}$cells repletion and age......54

Figure 31. Correlation between frequencies of $\mathrm{CD} 20^{+} \mathrm{T}$ cells and age ...................................55

Figure A1. Correlation between naïve and memory B cell frequencies and age......................64

Figure A2. Differences in B cell activation phenotype between memory/balanced and naïve type.

Figure A3. Differences in B cell cytokine phenotype between memory/balanced and naïve type

Figure A4. Differences in $\mathrm{CD}^{+} \mathrm{T}_{\mathrm{H}}$ cells maturation and CD62L expression phenotype between memory/balanced and naïve type.

Figure A5. Differences in $\mathrm{CD}^{+} \mathrm{T}_{\mathrm{C}}$ cells maturation and CD62L expression phenotype between memory/balanced and naïve type …………….................................................67

Figure A6. Differences in CD14 ${ }^{+}$myeloid cells activation and APC phenotype between memory/balanced and naïve type 
Figure A7. Differences in CD14 ${ }^{+}$myeloid cells cytokine phenotype between memory/balanced and naïve type I .............................................................................69

Figure A8. Differences in CD14 ${ }^{+}$myeloid cells cytokine phenotype between memory/balanced and naïve type II............................................................................70 


\section{List of tables}

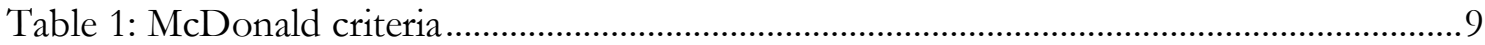

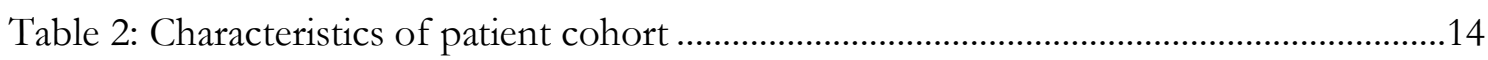

Table 3: Human monoclonal antibodies for flow cytometry ..................................................15

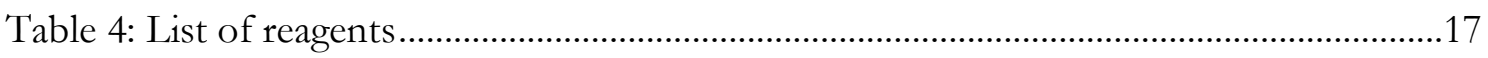

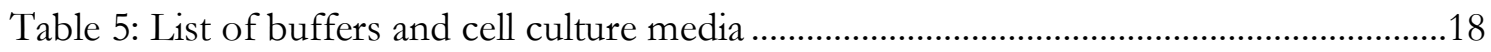

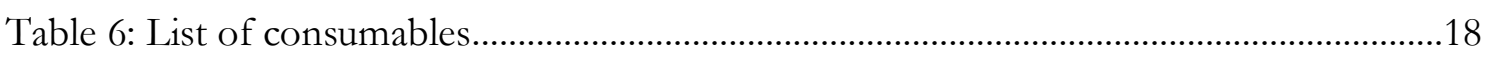

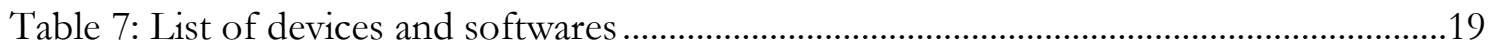

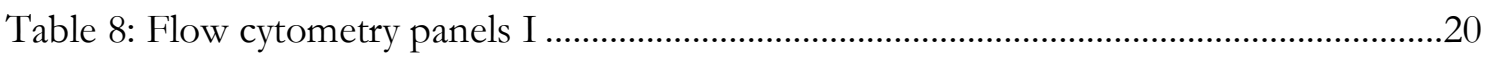

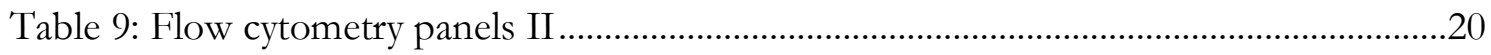

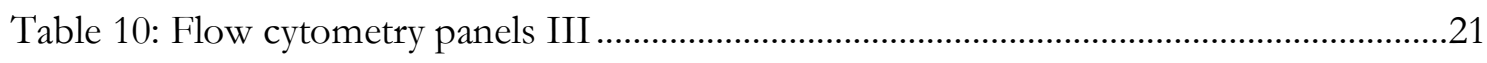

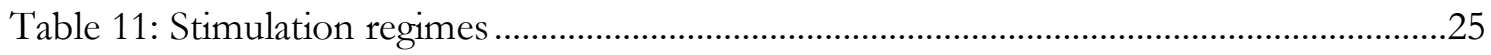

Table 12: Differences in immune cell phenotype after anti-CD20 depletion between patients with memory/balanced and naïve $\mathrm{B}$ cell phenotype pre-depletion. 


\section{Abbreviations}

ADCC antibody dependent cytotoxicity

APC antigen presenting cell

APRIL a proliferation-inducing ligand

AQP aquaporin

ARR annualized relapse rate

BAFF B cell activating factor

BBB blood brain barrier

BCR B cell receptor

BLyS B lymphocyte stimulator

BSA bovine serum albumin

CCR CC-chemokine receptor

CD cluster of differentiation

CDC complement dependent cytotoxicity

CIS clinically isolated syndrome

CNS central nervous system

CpG cytosine-phosphate-guanine

CSF cerebrospinal fluid

CXCL chemokine (C-X-C motif) ligand

DC dendritic cells

$\mathrm{ddH}_{2} \mathrm{O} \quad$ double-distilled water

DIS dissemination in space

DIT dissemination in time

DMEM Dulbecco's Modified Eagle's medium

DMF dimethyl fumarate

DMSO dimethyl-sulfoxide

DNA deoxyribonucleic acid

EAE experimental autoimmune encephalomyelitis

EBNA Epstein Barr nuclear antigen

EBV Epstein-Barr virus 


$\begin{array}{ll}\text { EDSS } & \text { expanded disability status scale } \\ \text { EDTA } & \text { ethylene diamine tetraacetic acid } \\ \text { FACS } & \text { fluorescence-activated cell sorting } \\ \text { FCS } & \text { fetal calf serum } \\ \text { FDA } & \text { Food and Drug Administration } \\ \text { HLA } & \text { human leukocyte antigen } \\ \text { i. } \text { m. } & \text { intramuscularly } \\ \text { i. v. } & \text { intravenously } \\ \text { ICD-10 } & \text { International Classification of Diseases, } 10^{\text {th }} \text { version } \\ \text { IFN } & \text { interferon } \\ \text { IgG } & \text { immunoglobulin G } \\ \text { IL } & \text { interleukin }\end{array}$

IMSGC International Multiple Sclerosis Genetics Consortium

LPS lipopolysaccharide

LT lymphotoxin

$\mathrm{mAb}$ monoclonal antibody

MBP myelin basic protein

MFI mean fluorescence intensity

MHC major histocompatibility complex

MOG myelin oligodendrocyte glycoprotein

MRI magnetic resonance imaging

MS multiple sclerosis

$\mathrm{Na}_{\mathrm{v}} \quad$ voltage-gated sodium channels

NF- $x \mathrm{~B} \quad$ nuclear factor kappa-light-chain-enhancer of activated B cells

NK cells natural killer cells

OCB oligoclonal bodies

p. o. $\quad$ per os

PBMC peripheral blood mononuclear cells

PBS phosphate buffered salt solution

PFA paraformaldehyde 
PKC protein kinase $\mathrm{C}$

PLP proteolipid protein

PMA phorbol 12-myristate 13-acetate

PPMS primary progressive multiple sclerosis

PRMS progressive relapsing multiple sclerosis

PTPRC protein tyrosine phosphatase receptor type C

rpm revolutions per minute

RPMI-1640 Roswell park memorial institute-1640

RRMS relapsing remitting multiple sclerosis

s. c.

subcutaneously

SPMS

secondary progressive multiple sclerosis

TBNK

$\mathrm{T}, \mathrm{B}, \mathrm{NK}$ cells

$\mathrm{T}_{\mathrm{C}}$ cells

cytotoxic $\mathrm{T}$ cells

$\mathrm{T}_{\mathrm{CM}}$

central memory T cells

TCR

$\mathrm{T}$ cells receptor

$\mathrm{T}_{\mathrm{EM}}$

effector memory $\mathrm{T}$ cells

$\mathrm{T}_{\mathrm{EMRA}}$

terminally differentiated effector memory $\mathrm{T}$ cells

$\mathrm{T}_{\mathrm{H}}$ cells

T helper cells

TLR

toll-like receptor

TMB

tetramethylbenzidine

$\mathrm{T}_{\mathrm{N}}$

naïve $\mathrm{T}$ cells

TNF

tumor necrosis factor

$\mathrm{T}_{\mathrm{reg}}$

regulatory $\mathrm{T}$ cells

$\mathrm{T}_{\mathrm{TD}}$

terminally differentiated $\mathrm{T}$ cells 


\section{Introduction}

\subsection{Multiple sclerosis}

Multiple sclerosis (MS, disseminate encephalomyelitis, ICD-10: G35) is a chronic primarily inflammatory disease of the central nervous system (CNS) in which myelin and axons are damaged due to focal lymphocytes' infiltration (Compston and Coles 2008). MS is a common neurological disorder and in some regions the lead cause of nontraumatic neurological disability in young adults (Browne et al. 2014).

\subsubsection{MS in general}

Epidemiology: as of 2007, approximately 1.3 million people worldwide were diagnosed with MS, in 20082.1 and in 2013 2.3, and is estimated at 2.5 million in 2018 (Dua et al. 2008; Browne et al. 2014). The incidence peak lays between 25-35 years, even though up to 3-5\% develop the disease before the age of 18. MS is more common in the United States, Europe, Canada, Australia and New Zealand, and is, on the other hand, rare in Asia and in tropical and subtropical areas. Women are twice to thrice more affected than men (lifetime risk of 1 in 200 women) (Ascherio and Munger 2016).

\subsubsection{Etiology, pathogenesis, pathophysiology and neuropathology}

\subsubsection{Genetic susceptibility and environmental factors}

Multiple sclerosis has a familial recurrence rate of approximately $20 \%$, whereas the risk in white northern Europeans is $0.3 \%$. Various genetic variations could be accounted for approximately $30 \%$ of overall disease risk, and more than 100 specific genetic regions were identified as associated with MS, explaining approx. one third of the entire genetic component, though non genetic factors have a larger contribution to the heterogeneity of the disease (International Multiple Sclerosis Genetics Consortium (IMSGC) et al. 2013; Brodin et al. 2015). An association between MS and the alleles of the human leukocyte antigens (HLA-) DR15 and DQ6 and the corresponding genotypes DRB1*1501, $D R B 5^{*} 0101, D Q A 1 * 0102$, and $D Q B 2 * 0602$ is described, and strongest in northern Europe. In other groups, MS is associated with HLA-DR4 and the genotypes DRB1*0405, $D Q A 1 * 0301$ and $D Q B 1 * 0302$. On the other hand, the loci HLA-C554 and HLA-DRB1*11 are suggested to have a protective effect (Olerup and Hillert 1991; Marrosu et al. 1992; Ramagopalan et al. 2007).

Epstein-Barr virus (EBV) infection and high anti-Epstein-Barr nuclear protein 1 (anti-EBNA1) IgG titers were suggested as a possible cause for MS (see below). A mechanism of molecular mimicry between DRB5*0101-EBV peptide complex and DRB1*1501-restricted myelin basic protein (MBP) was discussed to enlighten these findings. 
HLA-DRB1*1501 can present MBP to $\mathrm{CD} 4^{+} \mathrm{T}$ helper cells (CD4 ${ }^{+} \mathrm{T}_{\mathrm{H}}$ cells), and is the strongest known genetic risk factor for MS (Sawcer et al. 2014). The T cell receptor (TCR) is in fact not antigen specific, but epitope specific, meaning that a TCR could recognize many different antigens, that are often but not always, similar, a phenomenon called receptor degeneracy or polyspecificity (Wucherpfennig and Sethi 2011). A resemblance between the two complexes at the surface presented to the TCR leads to a failed recognition of MBP by $\mathrm{CD}^{+} \mathrm{T}_{\mathrm{H}}$ cells, leading to autoimmunity (Lang et al. 2002).

The hygiene hypothesis says, that multiple infections in childhood reduce the risk to develop autoimmune and allergic diseases in adolescence, by modulating the balance between $\mathrm{CD}^{+}{ }^{+} \mathrm{T}$ helper $1\left(\mathrm{CD}^{+}{ }^{+} \mathrm{T}_{\mathrm{H}} 1\right)$ and $\mathrm{CD}^{+}{ }^{+} \mathrm{T}_{\mathrm{H}} 2$ immunity, the dominant on at birth (Bach 2002). EBV is often mentioned in this context. Epstein-Barr virus is an enveloped $\gamma$ herpes virus, which infects more than $90 \%$ of the world's population, and persists in B lymphocytes. EBV is related to nasopharyngeal carcinoma, Burkitt lymphoma, and Hodgkin lymphoma, but its connection to autoimmune diseases remains unclear. An EBV infection in childhood is usually milder than a fully manifested infectious mononucleosis in adolescents. The epidemiology of infectious mononucleosis in adolescents and adults and of MS suggests that MS could be the result of an EBV infection in adolescents and adults (Ascherio et al. 2001). On the one hand, an early EBV infection is suggested to have a protective effect on the development of MS. A comparison between individuals who could recall an EBV infection and seronegative individuals or individuals who could not recall the infection led so an $2.9 \%$ odds ratio of MS (Martyn et al. 1993). On the other hand, anti-EBNA negative individuals have the lowest risk of MS, but when infected in adolescence, manifesting as infectious mononucleosis, their risk increases sharply, suggesting that individuals raised in hygienic environment have an increased risk of MS only after EBV infection (Ascherio and Munger 2007; Levin et al. 2010). In a related context it was mentioned, that stress and infections double the risk for relapse because of an increased immune response (Buljevac et al. 2003).

Several epidemiological studies have shown, that vitamin D $(25[\mathrm{OH}] \mathrm{D})$ has a protective role in reducing MS risk, especially in childhood and adolescence, and that MS patients do suffer from insufficiency. When corrected, MS patients show a beneficial outcome, clinically and in magnetic resonance imaging (MRI). The mechanism of the above-mentioned is not yet understood, but can be supported by immunomodulatory effects of vitamin $\mathrm{D}$, which increases interleukin (IL-)17 and induces of regulatory $\mathrm{T}\left(\mathrm{T}_{\mathrm{reg}}\right)$ cells (Cantorna et al. 2015; Hayes et al. 2015; Ascherio and Munger 2016).

As another possible environmental factor, the gut microbiome was discussed. Experimental autoimmune encephalomyelitis (EAE, and see 1.1.2.2) studies have shown, that changes in the gut microbiome could alter the severity and incidence of CNS inflammation. Nevertheless, a direct link between the gut microbiome and MS has yet to be discovered (Berer et al. 2011). 
Another risk factor known is cigarette smoking. Smoking individuals have an increased risk to develop MS, and passive exposure by parental smoking for example increases the risk to develop pediatric MS (Hernan et al. 2001; Mikaeloff et al. 2007).

\subsubsection{Pathogenesis}

Though the cause of MS is still unknown, there are many theories regarding the pathogenesis of MS, which can be divided into four main categories. In the first, only inflammation is the pathogenic factor, neurodegeneration follows. In the second the neurodegeneration happens first, the inflammation follows. In the third inflammation and neurodegeneration both lead independently to the clinical state. And in the fourth, inflammation reveals an existing predisposition for neurodegeneration, that leads to axonal vulnerability and cumulative injury (Compston and Coles 2008). From those four theories two main models are nowadays discussed: the extrinsic and the intrinsic model.

In the extrinsic model, autoreactive $\mathrm{T}$ cells activated in the periphery, most likely through processes of molecular mimicry (see EBV), migrate in the CNS alongside with activated $\mathrm{B}$ cells and monocytes, inducing inflammation, even though the CNS was earlier considered to be an immune privileged region, in which peripheral immune cells are largely not allowed to enter. EAE is an animal model based on that theory. In this model, emulsified CNS antigens are injected alongside with immune stimulants, encouraging the stimulation of pathogenic $\mathrm{CD}^{+}{ }^{+} \mathrm{T}_{\mathrm{H}} 1$ cells and pro-inflammatory $\mathrm{T}_{\mathrm{H}} 17$ cells in draining lymph nodes, which then enter the circulation and fulfil their effector function in the CNS through crossing the blood brain barrier (BBB) (Münz et al. 2009).

In the intrinsic model, the disease is triggered by intra-CNS events. Lymphocyte migration and activation of autoreactive lymphocytes are secondary. Those intra-CNS events still remain unclear, but CNS viral infection was suggested as a hypothesis (Ransohoff and Engelhardt 2012). In the context of microglia activation, it is suggested, that high concentrations of pro-inflammatory cytokines due to a peripheral immune reaction could result in transfer of cytokines across the $\mathrm{BBB}$, inducing perivascular macrophage activation, which in turn causes pro-inflammatory microglial activation. Meaning microglia-dependent neurodegeneration could be the result of indirect activation, without the need of autoreactive T cells (Dantzer et al. 2008).

\subsubsection{Pathophysiology}

Physiologically, mature oligodendrocytes synthesize myelin in order to better isolate the axons of nerve cells in the white matter in the CNS to allow rapid transmission of the action potential impulses. They build elongated processes which contact the nearby axons and cycle them, and so isolate the electrical impulses, preventing ion loss trough saltatory conduction (Compston et al. 2006). In chronic inflammation different kinds of reactive species (for example reactive oxygen or nitrogen species) are produced at inflamed regions, and are suspected to promote mitochondrial damage, and mitochondrial DNA mutations. This leads 
to mitochondrial insufficiency and ultimately to energy deficiency of the neurons, which have a high energy need in order to maintain a functional protein biosynthesis, neuroaxonal function and ionic homeostasis, which is crucial to the function of the neurons. Different compensatory mechanisms, among others voltage-gated sodium channels $\left(\mathrm{Na}_{\mathrm{v}} 1.2\right.$ and $\mathrm{Na}_{\mathrm{v}} 1.6$ ), try to maintain a balanced ionic homeostasis, however fail also due to excess accumulation of glutamate, the most common neurotransmitter in the CNS, which is excessively released during neuronal injury, promoting ionic imbalance. This axonal damage can spread anterograde, meaning in the distal axon terminal (known as "Wallerian degeneration"), possibly effecting the postsynaptic neurons, or retrograde effecting the perikaryon ("neuronal dying back"), and could possibly lead to neuronal necrosis or apoptosis (Friese et al. 2014).

This loss of axonal isolation after demyelination reduces the speed of action potential impulses through the axons enormously. Depolarization could go through the lesion, but at an extreme low velocity, explaining the delay in evoked potential and fatigue, both characteristic for MS. Depending on the location of the demyelinated lesions symptoms vary (Compston and Coles 2008). In addition, there is axonal transport disturbances and axonal transections in lesions that finally lead to significant axonal loss within the lesions (Kuhlmann et al. 2002).

\subsubsection{Neuropathology}

Robert Carswell described in 1838 the pathological anatomy and clinical features of MS as "a remarkable lesion of the spinal cord accompanied with atrophy" (Carswell 1838). The end stage of a demyelinating disease is the formation of a sclerotic plaque, and represents a long process including inflammation, demyelination, remyelination, oligodendrocyte loss and astrocytosis, leading to neuronal and axonal degeneration, which in turn leads to disruption of neuronal signaling.

In the histology one could identify four types of early MS lesions. Tissue injury associated with $\mathrm{T}$ cell infiltrates and macrophages (pattern 1), oligodendrocytes and myelin targeted immune reaction via complement activation or antibodies (pattern 2), hypoxia like injury via impaired mitochondrial function, as a result of inflammation-induced vascular damage or macrophage toxins (pattern 3), and possibly genetic dependent oligodendrocytes' predisposition to immune reaction (pattern 4) (Lucchinetti et al. 1996; Lucchinetti et al. 2000; Mahad et al. 2009).

\subsubsection{Role of T cells}

Already in early stages of MS, T cells can be detected in CNS lesions. As described in 1.1.2.1 above, an association between MS and different HLA alleles is suggested, and could in fact reflect the possible presentation of autoantigens to autoreactive $\mathrm{T}$ cells. In the neuropathology of MS, demyelination is the key factor. A theory is that myelin proteins or certain myelin peptides might be encephalitogenic, and therefore the target of those $\mathrm{T}$ cells. 
MBP, proteolipid protein (PLP) and myelin oligodendrocyte glycoprotein (MOG) are known to be recognized by circulating $\mathrm{CD}^{+} \mathrm{T}_{\mathrm{H}}$ cells of MS patients, but also of healthy individuals. This could be explained due to the fact that CNS antigens aren't presented to the differentiating $T$ cells in the thymus as a part of the negative selection in the central tolerance. Therefore, autoimmune $\mathrm{T}$ cells could survive this selection. Nevertheless, not all individuals with MBP/PLP/MOG specific $\mathrm{CD}^{+}{ }^{+} \mathrm{T}_{\mathrm{H}}$ cells develop MS, which raises the question: what causes these cells to migrate into the CNS and act upon their autoimmunity. In addition, only a minority of MS patients show anti-MBP or anti-MOG antibodies, which reinforces the active role of T cells (Hellings et al. 2001; Bielekova et al. 2004).

The most studied model of MS is EAE in mice. In this model, the major players are $\mathrm{CD}^{+} \mathrm{T}_{\mathrm{H}}$ cells, which after peripheral activation in lymph nodes migrate into the CNS, and are reactivated there by antigen-presenting cells (APCs), among others $\mathrm{CD} 11 \mathrm{c}^{+}$dendritic cells (DCs), leading to an inflammatory response, which in turn recruits monocytes and naïve $\mathrm{CD}^{+} \mathrm{T}$ cells into the CNS, fueling the inflammation (Quintana et al. 2014; Mundt et al. 2019). Those myelin reactive $C D 4^{+} T$ cells are mainly $T_{H} 1$ cells and $T_{H} 17$ cells, expressing CC-chemokine receptor 6 (CCR6) and secreting interferon- $\gamma$ (IFN- $\gamma$ ) and IL17-A respectively. An intermediate type was also detected in lesions, secreting both cytokines (Kebir et al. 2009; Cao et al. 2015).

An interest in the role of $\mathrm{CD}^{+}$cytotoxic $\left(\mathrm{T}_{\mathrm{C}}\right)$ cells and of $\mathrm{B}$ cells (see 1.1.2.7 below) came from observations of human MS. $\mathrm{CD}^{+} \mathrm{T}_{\mathrm{C}}$ cells are histologically the dominant T lymphocytes in white matter and in grey matter cortical demyelinating lesions, and their presence approximately correlates with axonal damage, indicating a key role (Frischer et al. 2009). Even in $\mathrm{CD}^{+} \mathrm{T}_{\mathrm{H}}$ cell driven EAE model autoreactive $\mathrm{CD} 8^{+} \mathrm{T}_{\mathrm{C}}$ cells are activated via cross presentation by monocytes or DCs in the CNS (Ji et al. 2013). Exact analysis of the TCRs of those $\mathrm{CD}^{+} \mathrm{T}_{\mathrm{C}}$ cells shows a local expansion of migrating $\mathrm{T}_{\mathrm{C}}$ cells, indicating an active role in the lesion formation. Different EAE models were developed in order to decipher the role of the $\mathrm{CD}^{+} \mathrm{T}_{\mathrm{C}}$ cells in MS lesions. Some models show a cytotoxic $\mathrm{CD}^{+} \mathrm{T}_{\mathrm{C}}$ cell function, causing glial apoptosis, others show a regulatory function, or even a cytotoxic function against the pathogenic $\mathrm{CD}^{+}{ }^{+} \mathrm{T}_{\mathrm{H}}$ cells (Hohlfeld et al. 2016).

In context of anti-CD20 mediated therapies, a small population of $\mathrm{CD}^{+}$and $\mathrm{CD} 8{ }^{+}$cells co-expressing CD20 (which was earlier considered to be a specific B cell marker) was also described. These cells can be depleted via anti-CD20 monoclonal antibody (-mAb), yet the difference in function to the $\mathrm{CD}^{-} 0^{-} \mathrm{T}$ cell population remains unclear (Gingele et al. 2018).

\subsubsection{Role of myeloid antigen presenting cells}

The dominant immune cells located in MS lesions in relapsing-remitting and in progressive phases are mononuclear phagocytes. Some differentiate from CNS originated microglia and some from peripheral monocytes, which migrate into the CNS during lesion formation. Those phagocytes can interact with other immune cells, such as T and B cells, and show two 
main functions in MS lesions: myelin damage caused by pro-inflammatory tissue damage, known as M1 differentiation, and removal of damaged tissue (debris) or tissue repair, known as M2 differentiation. Moreover, phagocytes are seen often near damaged axons, correlating with the extent of acute axonal destruction, indicating an active role in inducing inflammation via oxidative stress, secretion of pro-inflammatory cytokines, such as IL-6 and tumor necrosis factor (TNF-) $\alpha$, and matrix metalloproteinases, which in turn results in axonal damage in both grey and white matter (Lassmann et al. 1998; Trapp et al. 1998; Kouwenhoven et al. 2001; Kuhlmann et al. 2002; Bar-Or 2003). On the other hand, the phagocytes are suggested to have a necessary role in tissue repair mechanisms during lesion resolution among others via secretion of anti-inflammatory cytokines and growth factors, to promote oligodendrocyte differentiation. One speculates, that those two reversed roles may show the origin of said cells, suggesting that the monocyte derived phagocytes are the ones responsible for axonal damage, and that the microglia derived phagocytes are the ones assisting in tissue repair (Miron et al. 2013). Yet this theory has been recently disputed, showing that monocytes of MS patients respond to glucocorticoid therapy with a M2 differentiation (Fischer et al. 2019).

\subsubsection{Role of B cells}

B cells function as APCs, show modulatory function by cytokine secretion and are the precursor of antibody secreting plasma cells. Those functions of the B cell in the immune response have both pro- and anti-inflammatory components. Their key role in MS pathogenesis was emphasized by the undeniable therapeutic efficiency of anti-CD20-mAb, which deplete mostly B cells and CD20 ${ }^{+} \mathrm{T}$ cells, but not plasma cells, which are CD20- ${ }^{-}$, hence not reducing antibody production (Hauser et al. 2008).

The presence of B cells and of oligoclonal immunoglobulins (Ig, also known as oligoclonal bands, OCB) in the CSF was first observed in the 1950's, is seen in most MS patients, and is therefore used as a diagnostic criterion (Kabat und Freedman 1950). Moreover, B cells can be found not only in the CSF of MS patients but also in the parenchyma and in follicle like structures in the meninges (Lucchinetti et al. 2000; Serafini et al. 2004). The CNS seems to present a nesting milieu for the persistence and activation of $\mathrm{B}$ cells due to secretion of different chemokines, such as B cell activating factor (BAFF) and chemokine (C-X-C motif) ligand (CXCL)-13, which seem to be secreted by microglia and activated astrocytes (Krumbholz et al. 2005; Krumbholz et al. 2006; Kowarik et al. 2012).

By close examination of the above-mentioned Ig it was shown, that they are produced by clonally expanding B cells intrathecally (by comparing proteome and transcriptome of CSF B cells), and close examination of the CSF B cells showed indications for somatic hypermutation, which in turn suggests antigen-driven affinity maturation. Yet the antigens recognized by said antibodies remain unclear (Qin et al. 1998; Obermeier et al. 2008; Weber et al. 2011; Beltran et al. 2014). Further histological studies show Ig and complement depositions in MS lesions, suggesting that Ig alone (ADCC - antibody dependent 
cytotoxicity) or in combination with complement activation (CDC - complement dependent cytotoxicity) induce demyelination. As for possible targets for those Ig oligodendrocytes and myelin proteins such as MBP, PLP or MOG were suggested, but also neuroglial and astrocytic antigens (Genain et al. 1999; Elliott et al. 2012, and see 1.1.2.4 above). Whether the humoral reaction comes primary or secondary to CNS inflammation, remains unclear.

As for their function as APCs, B cells recognize foreign antigens via their B cell receptor (BCR), a membrane-bound Ig, which in turn are internalized and presented via constitutive expressed major histocompatibility complex class II (MHC-II) to the responding $\mathrm{CD}^{+} \mathrm{T}_{\mathrm{H}}$ cells. Once activated B cells express the co-stimulatory molecules CD80/86 resulting in T cell activation and inflammation (Lanzavecchia 1985). This antigen presenting function of $\mathrm{B}$ cells was demonstrated in the EAE model, emphasizing the importance of B cells as APC for the pathogenesis of MS (Molnarfi et al. 2013).

As mentioned, B cells have a modulatory function on other immune cells by secretion of pro- and anti-inflammatory cytokines. For example, B cells secrete IL-6, a pro-inflammatory cytokine which promotes the differentiation of $\mathrm{T}_{\mathrm{H}} 17$ and blocks the differentiation to $\mathrm{T}_{\text {reg }}$ cells, increasing inflammation. MS patients' B cells show an increased IL-6 and TNF- $\alpha$ secretion compared to healthy controls (Barr et al. 2012). At the same time, B and plasma cells are a source of anti-inflammatory cytokines such as IL-10 and IL-35. IL-10 downregulates the expression of $\mathrm{T}_{\mathrm{H}} 1$ cytokines, inhibits the differentiation of pro-inflammatory $\mathrm{T}_{\mathrm{H}} 1$ and $\mathrm{T}_{\mathrm{H}} 17$ cells, MHC-II, and costimulatory molecules on myeloid APCs, such as monocytes and DCs. IL-10 also blocks NF- $x \mathrm{~B}$ activity, which in turn promotes the secretion of pro-inflammatory cytokines, nitric oxide, and eicosanoids (Moore et al. 2001). MS patients' B cells show a decreased IL-10 secretion compared to healthy controls (Duddy et al. 2007).

When looking closely at the different B cells subpopulations, a difference can be seen between the naïve (CD27) and the memory $\left(\mathrm{CD} 27^{+}\right)$B cells. Duddy et al. (2007) described the differences between these populations in MS patients, showing a different cytokine profile, indicating different roles. They confirmed that IL-10 is almost exclusively produced by naïve B cells, and that the pro-inflammatory cytokines TNF- $\alpha$ and lymphotoxin (LT) are largely produced by memory B cells. They also described a difference in their activation profile, showing that memory B cells can be easier activated than the naïve B cells, and produce thereafter more pro-inflammatory cytokines (TNF- $\alpha, \mathrm{LT}$ ) for a fulminant immune reaction, whereas the naïve $\mathrm{B}$ cells produce the anti-inflammatory cytokine IL-10, to prevent an undesired reaction. 


\subsubsection{Symptoms and diagnosis}

Dependent on the CNS area in which the MS typical lesions develop, the symptoms can vary. A clinical manifestation indicates, in most patients, the involvement of visual, sensory, motor or autonomic system, or a combination of two or more (see 1.1.2.3 above). Hence very few symptoms are disease specific. On the other hand, two are characteristic for MS: Lhermitte's symptom (upon neck flexion runs an electrical sensation down the spine), and the Uhthoff phenomenon (symptom worsening when body temperature increases), which could help at diagnosis (Compston and Coles 2008).

The clinical course of the disease varies as well. It may include acute episodic periods of new neurological symptoms or worsening of pre-existing symptoms, known as relapses, a stable progressive deterioration of neurological functions in the absence of relapses, or a combination of both. Four possible clinical courses of MS were defined. Relapsing remitting (RR-) MS: episodes of acute worsening of neurological functions (relapses) followed by a variable recovery (complete or incomplete) with stable disease between the relapses. Primary progressive (PP-) MS: the disease progresses continuously from onset, i.e. gradual nearly steady worsening of neurological symptoms, occasional plateaus and temporary minor improvements may occur. Secondary progressive (SP-) MS: initial RRMS course of MS, followed by a progression. SPMS may or may not be associated with overlying relapses. Without treatment, approximately 50\% of RRMS patients convert to SPMS within 15 years after disease onset (Weinshenker et al. 1989). Progressive relapsing (PR-) MS: a rare variant showing from the beginning a primarily disease progression combined with clear acute relapses (Lublin et al. 1996).

The clinical severity of the disease is quantified using the Kurtzke Expanded Disability Status Scale (EDSS). Developed by John F. Kurtzke, the score is based on a neurological examination by a clinician, and ranges between 0.0, i.e. normal neurological exam and 10.0, i. e. death due to MS, in 0.5 steps (Kurtzke 1983).

As mentioned, the clinic of MS is very heterogenous. The diagnosis of MS is nowadays based on criteria including clinical, imaging and laboratory (CSF analysis) findings. These so-called McDonald criteria (Thompson et al. 2018) were first introduced in 2001 and were revised over time, leading to the criteria shown in Table 1 : 
Table 1: McDonald criteria (Thompson et al. 2018)

\begin{tabular}{|c|c|c|}
\hline Clinical attacks & $\begin{array}{l}\text { No. of lesions with } \\
\text { objective clinical evidence }\end{array}$ & $\begin{array}{l}\text { Additional data needed for a MS } \\
\text { diagnosis }\end{array}$ \\
\hline$\geq 2$ clinical attacks & $\geq 2$ & None \\
\hline$\geq 2$ clinical attacks & $\begin{array}{l}1 \text { (as well as clear-cut historical } \\
\text { evidence of a previous attack } \\
\text { involving a lesion in a distinct } \\
\text { anatomical location) }\end{array}$ & None \\
\hline$\geq 2$ clinical attacks & 1 & $\begin{array}{l}\text { Dissemination in space demonstrated by } \\
\text { an additional clinical attack implicating a } \\
\text { different CNS site or by MRI (DIS) }\end{array}$ \\
\hline one clinical attack & $\geq 2$ & $\begin{array}{l}\text { Dissemination in time demonstrated by } \\
\text { an additional clinical attack or by MR } \\
\text { or demonstration of CSF-specific } \\
\text { oligoclonal bands (DIT or OCB) }\end{array}$ \\
\hline one clinical attack & 1 & DIS and DIT or OCB \\
\hline $\begin{array}{l}\text { Progressive course } \\
\text { onset (PPMS) }\end{array}$ & See additional data & $\begin{array}{l}\text { One year of disability progression } \\
\text { (retrospectively or prospectively } \\
\text { determined) independent of clinica } \\
\text { relapse PLUS two of the following } \\
\text { criteria: }\end{array}$ \\
\hline
\end{tabular}

- One or more T2-hyperintense lesions characteristic of multiple sclerosis in one or more of the following brain regions: periventricular, cortical or juxtacortical, or infratentorial

- Two or more T2-hyperintense lesions in the spinal cord

- Presence of CSF-specific oligoclonal bands 


\subsubsection{MS therapies}

The infiltration of peripheral immune cells in the CNS has been the main target of MS therapies. Those immunomodulatory drugs reduce, on the one hand, immune cell activity and migration into the CNS, and thus the relapse frequency as well, but often have side effects of immune suppression, such as increased sensitivity to viral infections, development of malignancies, or even a deadly opportunistic infections (Haghikia et al. 2013). Despite decreased relapse frequency it is well known, that the MS therapies do not fully stop disease progression, and neuroaxonal damage progresses, accumulates and becomes permanent, ensuring future physical disability (Feinstein et al. 2015). The exact pathophysiological mechanisms that cause progressive neurodegeneration are not yet exactly defined. Whether they are the same that cause relapses, whether they are bystander mechanisms of inflammatory demyelination or whether there is a specific attack towards the neuroaxonal compartment, is still open.

\subsubsection{General principles}

Due to lack of knowledge of disease pathogenesis, MS patients are therapied according to the disease severity and progression. Twelve MS therapies approved by the Food and Drug Administration (FDA) can be divided into four major principals (Brück et al. 2013): (1) Immunosuppression: cladribine (per os; p. o.), mitoxantrone (intravenously; i. v.); (2) Immunomodulation: interferon beta (IFN- $\beta$ )- $1 \mathrm{a}$, IFN- $\beta-1 \mathrm{~b}$, peginterferon beta-1a, glatiramer acetate (GA; all subcutaneously/intramuscularly; s. c./i. m.), teriflunomide, dimethyl fumarate (DMF; both p.o.); (3) Migration inhibition: fingolimod (p.o.), natalizumab (anti- $\alpha_{4}$-Integrin-mAb, i. v.); (4) Cell depletion: alemtuzumab (anti-CD52-mAb), ocrelizumab (anti-CD20-mAb)

As an example for an immunomodulation therapy, one can look at IFN- $\beta$, GA or DMF. As described in 1.1.2.4 above, $\mathrm{T}_{\mathrm{H}} 1$ and $\mathrm{T}_{\mathrm{H}} 17$ are the main $\mathrm{CD}^{+} \mathrm{T}_{\mathrm{H}}$ cells populations causing the disease. IFN- $\beta$, GA and DMF shift the scale towards $\mathrm{T}_{\mathrm{H}} 2$ cell phenotypes, decreasing inflammation (Kozovska et al. 1999; Vieira et al. 2003; Zoghi et al. 2011).

The MS disease modifying therapy, according to current German guidelines (LL 312012 Diagnose und Therapie der Multiplen Sklerose), is chosen according to the disease activity of the patients, and can divided into four main indications (B cell depleting therapy with Ocrelizumab is approved for the treatment of RRMS and PPMS in Germany, but not yet included in the current guidelines): (1) MS as clinically isolated syndrome (CIS), mild/moderate disease activity: IFN- $\beta-1 \mathrm{a}$, IFN- $\beta-1 \mathrm{~b}$, GA (class I evidence); (2) RRMS: (a) high disease activity: alemtuzumab, fingolimod, natalizumab; mitoxantrone (cyclophosphamide); clinical studies. (b) mild/moderate disease activity: DMF, GA, IFN- $\beta-1 a$, IFN- $\beta-1 b$, peginterferon beta-1a, teriflunomide (azathioprine); (3) SPMS: with relapses: IFN- $\beta-1 \mathrm{a}$, IFN- $\beta-1 \mathrm{~b}$, mitoxantrone (cyclophosphamide); without relapses: mitoxantrone; (4) acute relapse therapy: methylprednisolone, plasmapheresis. 


\subsubsection{B cell targeted}

Nowadays there are three main ways to target B cells in the MS therapy: anti-CD20-mAb depleting peripheral B cells (see 1.2 below), anti-CD19-mAb (MEDI-551) depleting all $B$ and plasma cells, and BLyS (B Lymphocyte Stimulator)/BAFF and APRIL (a proliferation-inducing ligand) inhibitors (Atacicept). An overview of these therapies is shown in Figure 1:

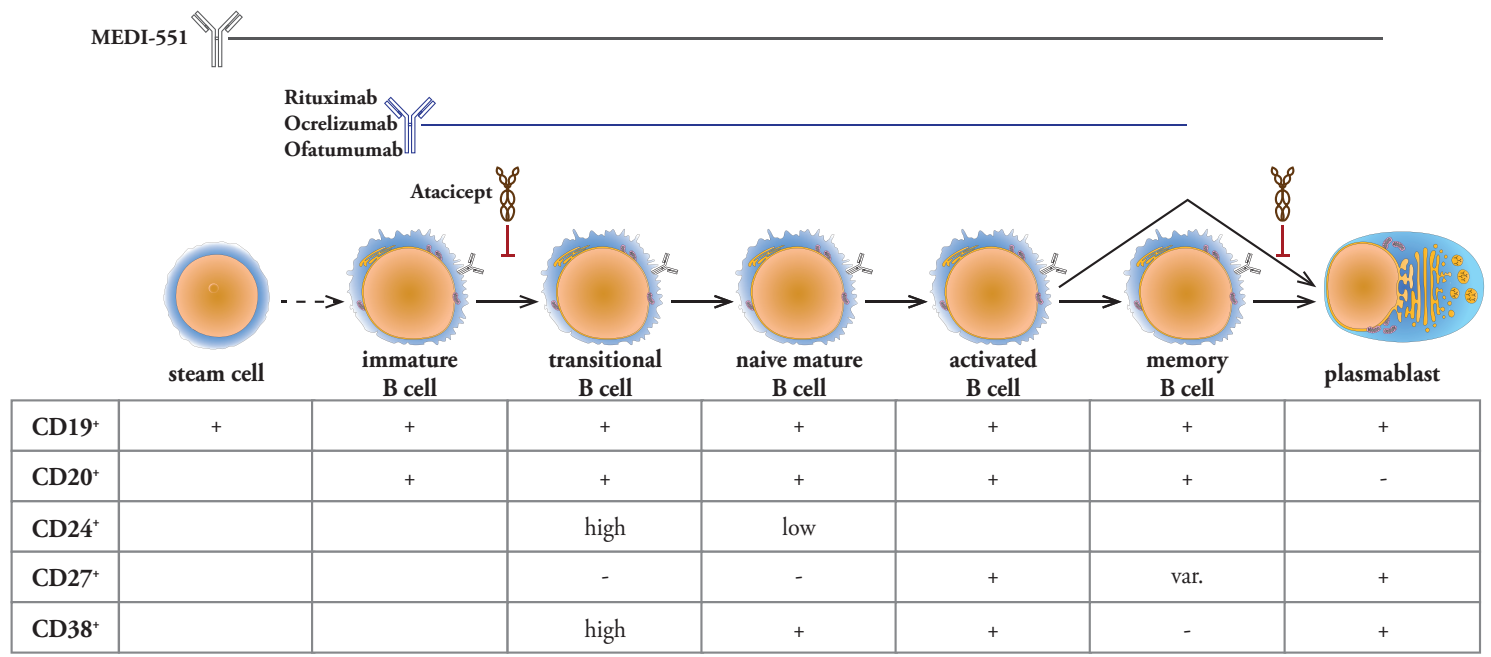

Figure 1. B cells targeted therapies. The figure shows the different B cell maturation phases and the therapeutic options for B cell inhibition/depletion (adapted from Bittner et al. 2017, with courtesy of Prof. Dr. med. Stefan Bittner).

\subsection{Anti-CD20 monoclonal antibodys (Rituximab, Ocrelizumab, Ofatumumab)}

Ocrelizumab as a new anti-CD20-mAb therapy is approved for the treatment of RRMS and PPMS. Rituximab as an anti-CD20-mAb therapy was often used as an off-label treatment for MS and in few clinical trials. Rituximab is a chimeric monoclonal anti-CD20-mAb depleting peripheral B cells, and has already been approved for treatment of B cell lymphoma and different autoimmune diseases (Gürcan et al. 2009). Ocrelizumab is a humanized IgG1 anti-CD20-mAb with decreased immunogenicity compared to rituximab, and binds to a different yet overlapping epitope on the CD20 molecule than rituximab. Ofatumumab is a fully humanized anti-CD20-mAb, which binds a different epitope than rituximab and ocrelizumab.

\subsubsection{Mechanism of action of anti-CD20 monoclonal antibodys}

All three antibodies deplete circulating $\mathrm{CD} 20^{+}$cells almost completely, via a combination of antibody-dependent cellular cytotoxicity and complement-dependent cytotoxicity resulting in apoptosis (Reff et al. 1994), with a limited penetration of lymphoid tissues (Kamburova et al. 2013). Rituximab doesn't efficiently cross the BBB, but does deplete B cells in the CSF and $\mathrm{CNS}$ perivascular spaces. OCB changes after rituximab treatment are undetectable 
(Cross et al. 2006; Martin et al. 2009). In comparison with rituximab, ocrelizumab shows increased antibody-dependent cellular cytotoxicity and reduced complement-dependent cytotoxicity, and ofatumumab has a higher binding affinity to CD20.

\subsubsection{Clinical trials in MS}

Four clinical trials with rituximab have been completed in MS (Barun and Bar-Or 2012). The most important of them, the HERMES trial, a randomized, placebo-controlled phase II trial in 104 patients with RRMS, has shown a 91\% reduction of gadolinium enhancing lesions and a reduction of relapse rates by $49 \%$ after 48 weeks against placebo (Hauser et al. 2008). On the other hand, the OLYMPUS trial, a phase II/III trial in 439 patients with PPMS, failed to show a reduction in confirmed disease progression after 96 weeks (Hawker et al. 2009). Rituximab as off-label MS therapy is commonly administered i. v. either at a dose of $1000 \mathrm{mg}$ on days 1 and 15, or $375 \mathrm{mg} / \mathrm{m}^{2}$ in 4-weekly doses every 6-12 months (Kim et al. 2013; Melzer and Meuth 2014). Rituximab has shown in addition a successful depletion of B cells in the CSF and in the perivascular spaces (Martin et al. 2009). An intrathecal application in lower dosage was also investigated, presenting a depletion of peripheral B cells, but a moderate depletion of CSF B cells (Svenningsson et al. 2015).

The OPERA trials (I and II, both phase III trials) with ocrelizumab in 1656 RRMS patients showed a 47\% reduction of annualized relapse rates (ARRs), a 95\% reduction of gadolinium-enhanced T1 lesions and 40\% reduction of confirmed disability compared with IFN- $\beta$-1a after 96 weeks. Ocrelizumab was administered at $600 \mathrm{mg}$ i. v. every 6 months (first cycle: twice $300 \mathrm{mg}$ i. v. 2 weeks apart, then single dose $600 \mathrm{mg}$ i. v.).

With regards to PPMS, ocrelizumab showed in a placebo-controlled phase III trial in 488 PPMS patients, the ORATORIO trial, in which it was administered at $300 \mathrm{mg}$ i. v., 2 weeks apart, every 6 months, a 24\% lower risk for confirmed disability progression after 12 weeks and after 24 weeks. T2-weighted lesion volumes were 3.4\% lower than at baseline and brain volume loss was $17.5 \%$ lower than in placebo patients. Ocrelizumab was therefore the first treatment ever to show clinical efficacy in patients with PPMS (Sorensen and Blinkenberg 2016).

\subsection{Atacicept}

Atacicept is a human recombinant fusion protein blocking both BLyS/BAFF and APRIL, two regulatory ligands regulating $\mathrm{B}$ and plasma cell survival, $\mathrm{T}$ cell stimulation and antibody isotype switching (Schneider 2005). Atacicept is not approved for MS therapy and showed negative effects in clinical trials. RRMS patients injected weekly with atacicept in a placebo-controlled phase II trial (the ATAMS trial) had twice more relapses than the placebo group (Kappos et al. 2014). 


\subsection{Aims of the study}

B cell depletion as MS therapy is relatively new, and therefore immunological consequences and long-term (side) effects of this therapy are still unknown. MS was always considered to be driven by pathogenic $T$ cells, but the significant effects of $\mathrm{B}$ cell depletion on relapses and MRI lesions point to a possibly greater role of B cells in the MS pathogenesis than thought. However, the long-term effects of $\mathrm{B}$ cell depletion, their phenotype during repletion and the effects of $\mathrm{B}$ cell depletion on other immune cell populations are largely unknown. Therefore, I aimed to identify and characterize B cell and other immune cell phenotypes and kinetics during B cell depletion and repletion phases. This work is also aiming at offering follow up and kinetic monitoring tools for treated patients with MS during B cell depletion treatments.

\subsubsection{Direct effects of anti-CD20 depletion on $\mathrm{CD} 20^{+} \mathrm{B}$ and $\mathrm{T}$ cells}

To detect differences in B cell maturation and activation phenotype, antigen presentation, co-stimulation and cytokine secretion capacities before B cell depletion and during repletion.

To detect differences between $\mathrm{CD} 20^{+} \mathrm{T}$ cells before $\mathrm{B}$ cell depletion and during repletion and to identify repletion kinetics of $\mathrm{CD} 20^{+}$cell populations.

\subsubsection{Indirect effects on other immune cell populations}

Detection of changes in $\mathrm{CD}^{-} 0^{-} \mathrm{T}$ cells maturation phenotype and migration potential.

Detection of altered myeloid cells' activation phenotype, of antigen presentation, co-stimulation and cytokine secretion capacities upon repletion compared to their pre-depletion state, with respect to pro- and anti-inflammatory phenotypes.

\subsubsection{Correlation with clinical parameters}

Identification of the effects of B cell depletion on clinical outcomes (relapses, progression) and of long-term effects on other immune populations. 


\section{Materials and Methods}

\subsection{Patients}

Blood samples were taken from 15 MS patients treated at the Department of Neurology at the University Medical Centre in Göttingen, Germany, all diagnosed with RRMS according to the McDonald criteria 2011. Blood was drawn before therapy induction with rituximab and sequentially afterwards, in various intervals. Blood samples were taken before a new dosage of rituximab was given. A total number of 95 samples has been collected and analyzed longitudinally, during the depletion and various repletion phases. Furthermore, clinical data were collected from all patients, as shown in Table 2. All participants did provide informed consent prior to study enrolment as approved by the Göttingen University ethics review board (\#19/09/10 and \#03/04/14).

Table 2: Characteristics of patient cohort

\section{Characteristic}

Age (years; mean $\pm \mathrm{SD})$

Age at begin of study (years; mean $\pm \mathrm{SD}$ )

Sex

EDSS score at start of the study $2.5 \pm 3.5$

(median $\pm \mathrm{IQR} /$ range)

Time since multiple sclerosis diagnosis $10.76 \pm 6.31$

(years; mean $\pm \mathrm{SD}$ )

Last treatment before Rituximab (cases) Dimethylfumarate 2

Fingolimod 6

Glatiramer acetate $\quad 1$

Natalizumab 2

Azathioprine 1

None (i. e. treatment naïve) 3 
Table 2: Characteristics of patient cohort

$\begin{array}{lll}\text { Previous treatments (cases) } & \text { Dimethylfumarate } & 2 \\ & \text { Fingolimod } & 9 \\ & \text { Glatiramer acetate } & 4 \\ & \text { Interferon beta-1a } & 6 \\ & \text { Interferon beta-1b } & 2 \\ & \text { Natalizumab } & 6 \\ & \text { Azathioprine } & 1 \\ & \text { Cortisone (in last six months } & 4 \\ \text { before first anti-CD20 } & \\ \text { Number of treatments before Rituximab } & 2.38 \pm 1.12 & \\ \text { (mean } \pm \text { SD) } & & 6 \text { negatives } \\ \text { Antibody tests (cases, others unknown) } & \text { AQP4 } & 5 \text { negatives } \\ \text { treatment) } & \text { MOG } & \\ \text { Situximab since (years; mean } \pm \text { SD) } & 2.68 \pm 0.658 & \\ \text { Pre-/dep./early rep./late rep. (samples) } & 15 / 12 / 10 / 10 & \end{array}$

\section{$2.2 \quad$ Materials}

Table 3: Human monoclonal antibodies for flow cytometry

$\begin{array}{lllll}\text { Antigen } & \text { Fluorochrome } & \text { Clone } & \text { Dilution } & \text { Manufacturer } \\ \text { CD4 } & \text { PE-Cy7 } & \text { RPA-T4 } & 1: 100 & \text { BD Bioscience } \\ \text { CD8 } & \text { PerCP-Cy5.5 } & \text { RPA-T8 } & 1: 100 & \text { BD Bioscience } \\ \text { CD8a } & \text { PE } & \text { HIT8a } & 1: 100 & \text { eBioscience } \\ \text { CD14 } & \text { FITC } & \text { M5E2 } & 1: 100 & \text { BD Bioscience } \\ \text { CD14 } & \text { PE-CF594 } & \text { M } \varphi \text { P9 } & 1: 100 & \text { BD Bioscience } \\ \text { CD14 } & \text { BV421 } & \text { M } \varphi \text { P9 } & 1: 100 & \text { BD Bioscience }\end{array}$


Table 3: Human monoclonal antibodies for flow cytometry

\begin{tabular}{|c|c|c|c|c|}
\hline CD19 & APC & HIB19 & $1: 100$ & BD Bioscience \\
\hline CD19 & PerCp-Сy5.5 & HIB19 & $1: 100$ & BioLegend \\
\hline CD19 & FITC & HIB19 & $1: 100$ & BD Bioscience \\
\hline CD19 & PE-Cy5 & HIB19 & $1: 100$ & BD Bioscience \\
\hline $\mathrm{CD} 20$ & APC-Сy7 & L27 & $1: 100$ & BD Bioscience \\
\hline $\mathrm{CD} 20$ & $\mathrm{PE}$ & REA780 & $1: 100$ & Miltenyi \\
\hline $\mathrm{CD} 24$ & PerCp-Cy5.5 & ML5 & $1: 100$ & BioLegend \\
\hline $\mathrm{CD} 25$ & BV605 & BC96 & $1: 100$ & BioLegend \\
\hline $\mathrm{CD} 27$ & PacificBlue & $\mathrm{O} 323$ & $1: 100$ & BioLegend \\
\hline CD38 & FITC & HIT2 & $1: 100$ & BioLegend \\
\hline $\mathrm{CD} 40$ & PE/DazzleTM594 & $5 \mathrm{C} 3$ & $1: 100$ & BioLegend \\
\hline CD45RA & FITC & HI100 & $1: 50$ & BD Bioscience \\
\hline CD45RO & A700 & UCHL1 & $1: 100$ & BD Bioscience \\
\hline CD62L & $\mathrm{PE}$ & DREG-56 & $1: 100$ & BD Bioscience \\
\hline CD69 & FITC & FN50 & $1: 100$ & BioLegend \\
\hline CD80 & PE-Cy7 & L307.4 & $1: 100$ & BD Bioscience \\
\hline CD86 & BV421 & 2331 (FUN-1) & $1: 100$ & BD Bioscience \\
\hline CD95 (FAS) & $\mathrm{PE}$ & DX2 & $1: 100$ & BioLegend \\
\hline CD150 & BV421 & A12 & $1: 100$ & BD Bioscience \\
\hline MHCII & APC & Tü36 & $1: 100$ & BioLegend \\
\hline IL-6 & FITC & MQ2-13A5 & $1: 50$ & BD Bioscience \\
\hline IL-10 & PE-CF594 & JES3-19F1 & $1: 50$ & BD Bioscience \\
\hline TNF- $\alpha$ & A700 & MAb11 & $1: 50$ & BD Bioscience \\
\hline Dead/Live & ZombieAqua ${ }^{\mathrm{TM}}$ & & $1: 500$ & BioLegend \\
\hline Dead/Live & ZombieNIRTM & & $1: 500$ & BioLegend \\
\hline
\end{tabular}


Table 4: List of reagents

\section{Reagents}

BD FACS Clean ${ }^{\mathrm{TM}}$

BD FACS Flow ${ }^{\mathrm{TM}}$

BD FACS Rinse ${ }^{\mathrm{TM}}$

BioColl separation solution

CpG oligodeoxynucleotides

Cytofix/Cytoperm ${ }^{\mathrm{TM}}$

DMEM (Dulbecco's Modified Eagle's medium)

DMSO (dimethyl-sulfoxide)

EDTA (ethylene diamine tetraacetic acid Carl Roth disodium salt dihydrate)

Ethanol 100\%

Fc-Block ${ }^{\mathrm{TM}}$

FCS (fetal calf serum)

GolgiPlug ${ }^{\mathrm{TM}}$

Ionomycin

L-glutamine

LPS (lipopolysaccharide)

PBS (phosphate buffered salt solution)

Perm/Wash ${ }^{\text {TM }}$ buffer, 10x

PFA (para-formaldehyde)

PMA (phorbol 12-myristrate 13-acetate)

RPMI-1640 (Roswell park memorial Sigma Aldrich

institute-1640)

Sodium pyruvate $100 \mathrm{mM}$

TrypanBlue

$\beta$-mercaptoethanol

\section{Manufacturer}

BD Biosciences

BD Biosciences

BD Biosciences

Biochrom

Sigma Aldrich

BD Biosciences

Merck Millipore

BioLegend

Sigma Aldrich

BD Biosciences

Sigma Aldrich

Sigma Aldrich

Sigma Aldrich

Sigma Aldrich

BD Biosciences

Merck Millipore

Sigma Aldrich

Sigma Aldrich

Sigma Aldrich

Sigma Aldrich 
Table 5: List of buffers and cell culture media

\section{Solution}

RPMI $_{\text {complete ("whole-medium") }}$

Cryo-medium

FACS buffer

Table 6: List of consumables

\section{Product}

96 well plates, flat bottom (flat-well)

96 well plates, round bottom (U-well)

FACS tubes, $5 \mathrm{ml}$

Micro tubes $(0.1 \mathrm{ml}, 0.5 \mathrm{ml}, 1 \mathrm{ml}, 1.5 \mathrm{ml})$

Multistep pipettes, $1 \mathrm{ml}$

Pipettes $(10 \mu \mathrm{l}, 200 \mu \mathrm{l}, 1000 \mu \mathrm{l})$

Pipettes $(5 \mathrm{ml}, 10 \mathrm{ml}, 25 \mathrm{ml})$

\section{Composition}

0.5l RPMI-1640, $50 \mathrm{ml}$ FCS, $5 \mathrm{ml}$ sodium pyruvate, $\quad 5 \mathrm{ml} \quad$ L-glutamine, $\quad 0.5 \mathrm{ml}$ $\beta$-mercaptoethanol $60 \% \mathrm{RPMI}_{\text {complete }}, 20 \% \mathrm{FCS}, 20 \%$ DMSO

$2 \%$ FCS in PBS

\section{Manufacturer}

Sarstedt

Sarstedt

Sarstedt

Eppendorf

Eppendorf

Sarstedt

Sarstedt 
Table 7: List of devices and softwares

\section{Device}

BBD 6220 cell incubator

Centrifuge 5415R

Centrifuge 5810R

CKX41 light microscope

FACS LSRII Fortressa

Neubauer chamber

SAFE 2020 clean bench

\section{Software}

FACSdiva $^{\mathrm{TM}}$ 6.1.2

FlowJo' ${ }^{\text {TM }}$ 10.5.3

GraphPad Prism ${ }^{\text {TM }} 7 \mathrm{a}$

Adobe $^{\mathrm{TM}}$ Illustraitor ${ }^{\mathrm{TM}}$ CS6 16.0.4

\section{Manufacturer}

ThermoScientific

Eppendorf

Eppendorf

Olympus

BD Biosciences

Superior Marienfeld

ThermoScientific

\section{Manufacturer}

BD biosciences

Tree Star Inc.

GraphPad software Inc.

Adobe ${ }^{\mathrm{TM}}$

\subsection{Methods}

PBMC isolation, processing, cryopreservation and unfreezing subsequently were performed according to established protocols at the laboratory.

\subsubsection{PBMC isolation}

Blood was drawn via phlebotomy into EDTA tubes in order to prevent cell agglutination, and then transferred into sterile tubes and diluted with PBS (1:3). In order to create a "Ficoll gradient" in order to isolate the peripheral blood mononuclear cells, $20 \mathrm{ml}$ BioColl $^{\mathrm{TM}}$ were added to the blood-PBS suspension, which was then centrifuged for 35 minutes at $448 \mathrm{~g}$ and $21^{\circ} \mathrm{C}$ with low acceleration and without brake. After centrifugation, the PBMC were concentrated between the BioColl ${ }^{\mathrm{TM}}$ and the plasma layer. This layer was transferred into a new tube, diluted twice with DMEM, and centrifuged (10 minutes at $1250 \mathrm{rpm}$ and $4^{\circ} \mathrm{C}$ ) in order to remove unwanted residues. After resuspension with $5 \mathrm{ml}$ DMEM the cells were counted under the microscope (see 2.3.2.2 below). For conservation, the cells were diluted to a count of $4 \cdot 10^{6} \cdot \mathrm{ml}^{-1}$ in DMEM. The conservation tubes were filled with $500 \mu \mathrm{l}$ cell suspension and $500 \mu \mathrm{l}$ cryo-medium, achieving $2 \cdot 10^{6}$ cells per tube. The tubes were frozen at $-80^{\circ} \mathrm{C}$ using an ethanol box, and so cooling slowly at $1^{\circ} \mathrm{K}$ per minute. The tubes were stored at $-80^{\circ} \mathrm{C}$. 


\subsubsection{Flow cytometry panels}

To answer the questions presented at the introduction, various flow cytometry stains under different stimulation regimes were used. This method had two leading limitations. the patients' samples, which were limited and not reproducible, and a potential spectral overlap of the fluorophores. The latter limits the number of fluorochromes to be used, without a too pronounced spectral overlap, which would lead in an unspecific signal. Therefore, the following panels were developed in order to achieve maximal knowledge per staining with the minimal number of panels needed. The final panels are presented in Tables 8-10:

Table 8: Flow cytometry panels I

\section{\#1 B cell subset}

$\begin{array}{llllll}\text { CD19 } & \text { APC } & \text { CD14 } & \text { FITC } & \text { CD19 } & \text { PerCp-Cy5.5 } \\ \text { CD20 } & \text { APC-Cy7 } & \text { CD19 } & \text { PerCp-Cy5.5 } & \text { CD25 } & \text { BV605 } \\ \text { CD24 } & \text { PerCp-Cy5.5 } & \text { CD40 } & \text { PE/Dazzle } 5 \text { 594 } & \text { CD40 } & \text { PE/Dazzle } 5 \text { 594 } \\ \text { CD27 } & \text { PacificBlue } & \text { CD80 } & \text { PE-Cy7 } & \text { CD69 } & \text { FITC } \\ \text { CD38 } & \text { FITC } & \text { CD86 } & \text { BV421 } & \text { CD80 } & \text { PE-Cy7 } \\ \text { Dead/Live } & \text { ZombieAqua }{ }^{\text {TM }} & \text { MHC-II } & \text { APC } & \text { CD86 } & \text { BV421 } \\ & & \text { CD95 (FAS) } & \text { PE } & \text { MHC-II } & \text { APC } \\ & & \text { Dead/Live } & \text { ZombieNIRTM } & \text { CD95 (FAS) } & \text { PE } \\ & & & & \text { Dead/Live } & \text { ZombieNIR }\end{array}$

Table 9: Flow cytometry panels II

\section{\#3 major immune cell populations}

$\begin{array}{ll}\text { CD4 } & \text { PE-Cy7 } \\ \text { CD8a } & \text { PE } \\ \text { CD14 } & \text { PE-CF594 } \\ \text { CD19 } & \text { FITC } \\ \text { CD150 } & \text { BV421 } \\ \text { MHC-II } & \text { APC } \\ \text { Dead/Live } & \text { ZombieAqua }^{\text {TM }}\end{array}$

\section{\#5 cytokine secretion}

$\begin{array}{ll}\text { CD14 } & \text { BV421 } \\ \text { CD19 } & \text { PE-Cy5 } \\ \text { IL-6 } & \text { FITC } \\ \text { IL-10 } & \text { PE-CF594 } \\ \text { TNF- } \alpha & \text { A700 } \\ \text { Dead/Live } & \text { ZombieNIR }{ }^{\text {TM }}\end{array}$


Table 10: Flow cytometry panels III

\section{\#2 T cell subset}

$\begin{array}{llll}\text { CD4 } & \text { PE-Cy7 } & \text { CD4 } & \text { PE-Cy7 } \\ \text { CD8 } & \text { PerCP-Cy5.5 } & \text { CD8 } & \text { PerCP-Cy5.5 } \\ \text { CD20 } & \text { APC-Cy7 } & \text { CD14 } & \text { PE-CF594 } \\ \text { CD45RA } & \text { FITC } & \text { CD19 } & \text { APC } \\ \text { CD45RO } & \text { A700 } & \text { CD20 } & \text { PE } \\ \text { CD62L } & \text { PE } & \text { CD25 } & \text { BV605 } \\ \text { Dead/Live } & \text { ZombieAqua }{ }^{\mathrm{TM}} & \text { CD45RA } & \text { FITC } \\ & & \text { CD45RO } & \text { A700 } \\ & & \text { Dead/Live } & \text { ZombieAqua }^{\mathrm{TM}}\end{array}$

Panel \#1, B cell subset allows the characterization of following maturation phases through surface antigens (and see Figure 1): transitional immature B cells (CD24 $4^{\text {high }}, \mathrm{CD} 27^{-}, \mathrm{CD} 38^{\text {high }}$ ); mature naïve B cells $\left(\mathrm{CD} 27^{-}, \mathrm{CD} 38^{+}\right)$; activated B cells $\left(\mathrm{CD} 27^{+}, \mathrm{CD} 38^{+}\right)$; memory B cells $\left(\mathrm{CD} 27^{\mathrm{var}}, \mathrm{CD} 38^{-}\right)$; plasmablasts $\left(\mathrm{CD} 20^{-}, \mathrm{CD} 27^{+}, \mathrm{CD} 38^{+}\right)$.

Panel \#2 and \#6, T cell subsets, allow the general characterization of $\mathrm{T}$ cell maturation phases (an accurate characterization requires the analysis of six surface antigens) and of $\mathrm{CD} 20^{+} \mathrm{T}$ cells, those through the following surface antigens: CD45: also known as Protein tyrosine phosphatase receptor type C (PTPRC), a type I transmembrane protein, that is present in various isoforms on all differentiated hematopoietic cells (except erythrocytes and plasma cells), and an essential regulator of $\mathrm{T}$ and $\mathrm{B}$ cell antigen receptor signaling, either via extracellular co-stimulation or via intracellular activation of various kinases required for the antigen receptor signaling (Holmes 2006). CD45 has two main isoforms: (1) CD45RA: typical for naïve T cells; (2) CD45RO: the shortest CD45 isoform, expressed by activated and memory $\mathrm{T}$ cells. These $\mathrm{CD}^{2} 5 \mathrm{RO}^{+}$cells are rare in neonates and progressively accumulate with age. CD62L: also known as L-selectin, is a cell adhesion molecule found on leukocytes. CD62L acts as a docking molecule, allowing lymphocytes to enter secondary lymphoid tissues via high endothelial venules, which in turn express the passing ligands. Through the adhesion the lymphocytes' circulation speed slows down, allowing entry into secondary lymphoid organs. CD62L is commonly found on the surface of T cells (Cotran et al. 1999). 
Figure 2 shows the $\mathrm{T}$ cell maturation phases as analyzed in the study:

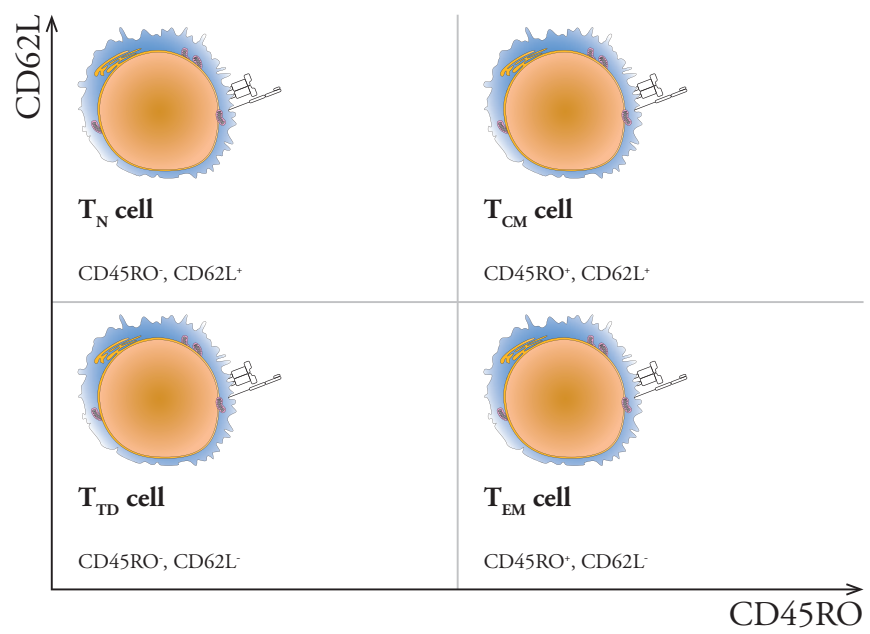

Figure 2. $\mathrm{T}$ cell maturation. The figure shows the four main $\mathrm{T}$ cell maturation phases, naïve $\mathrm{T}$ cells $\left(\mathrm{T}_{\mathrm{N}}\right)$, central memory $\mathrm{T}$ cells $\left(\mathrm{T}_{\mathrm{CM}}\right)$, effector memory $\mathrm{T}$ cells $\left(\mathrm{T}_{\mathrm{EM}}\right)$ and terminally differentiated $\mathrm{T}$ cells $\left(\mathrm{T}_{\mathrm{TD}}\right.$ ), differentiated through CD45RO and CD62L (own representation based on Sallusto et al. 2004; Holmes 2006; Mahnke et al. 2013).

Naïve $T$ cells $\left(T_{N}\right)$ leave the thymus epitope specific after undergoing positive and negative selection, and migrate into the periphery as a part of an immune response after antigen encounter. After antigen elimination, more that $95 \%$ of the effector $\mathrm{T}$ cells die, the rest differentiate into long-living memory T cells.

The CD45RO ${ }^{+}$memory $\mathrm{T}$ cells can be divided into two groups. Central memory $\mathrm{T}$ cells $\left(\mathrm{T}_{\mathrm{CM}}\right)$ and effector memory $\mathrm{T}$ cells $\left(\mathrm{T}_{\mathrm{EM}}\right)$ both express CD45RO, but differ in their cytokine profile and their function. $\mathrm{T}_{\mathrm{CM}}$ produce IL-2 (a T cell differentiation promoting cytokine, which promotes the differentiation into $\mathrm{T}_{\text {reg }}$ and into $\mathrm{T}_{\mathrm{CM}}$ and $\mathrm{T}_{\mathrm{EM}}$ (Liao et al. 2011; ArenasRamirez et al. 2015) and lack immediate killing activity, while $\mathrm{T}_{\mathrm{EM}}$ produce mostly IFN- $\gamma$ and TNF- $\alpha$, but not IL-2, and are capable of immediate cytotoxicity.

Studies have shown, that in humans some memory $\mathrm{T}$ cells, terminally differentiated $\mathrm{T}$ cells ( $\mathrm{T}_{\mathrm{TD}}$, also known as terminally differentiated effector memory $\mathrm{T}$ cells $\left[\mathrm{T}_{\mathrm{EMRA}}\right]$ ), re-express naive $\mathrm{T}$ cell surface antigen CD45RA, and down-regulate the expression of CD62L, representing a terminal stage of effector differentiation (Sallusto et al. 2004; Surh and Sprent 2008; Sathaliyawala et al. 2013).

As Figure 2 shows, $\mathrm{T}_{\mathrm{N}}$ and $\mathrm{T}_{\mathrm{CM}}$ express $\mathrm{CD} 62 \mathrm{~L}$ as they need to enter secondary lymph nodes, either to encounter their antigen, or to re-enter secondary lymphoid organs to proliferate upon antigen re-encountering. $\mathrm{T}_{\mathrm{EM}}$ and $\mathrm{T}_{\mathrm{TD}}$ do not express $\mathrm{CD} 62 \mathrm{~L}$, as they circulate in the periphery and have immediate effector functions upon encountering antigen (Kohn et al. 2012).

Panels \#2B and \#4, APC and B cell activation allow the characterization of following surface antigen related to antigen presentation and to general activation: MHC-II: a surface antigen used to present internalized antigens to the corresponding $\mathrm{CD}^{+}{ }^{+} \mathrm{T}$ cells (Owen et al. 2013). 
CD40: a type I glycoprotein involved in B cell differentiation, co-stimulation, isotype class-switching and protection of B cells from apoptosis. CD40 is important for the B cell-T cell interaction by binding CD40 ligand (CD40L) on T cells (Kawabe et al. 1994). CD80/CD86: a type I glycoprotein also known as B7-1/2 and are expressed on antigen-presenting cells. An interaction with $\mathrm{CD} 28$ is used as a co-stimulatory signal to activate the passing T cell (Owen et al. 2013). CD25: a type I transmembrane glycoprotein found on activated mononuclear immune cells, in association with CD122 and CD132 it forms the IL-2 receptor complex (Sakaguchi et al. 1995; Buckner 2010). CD69: this type II transmembrane protein is a member of the C-type lectin family and is involved in early lymphocyte activation. Among other functions: signal-transmitting receptor in platelets and natural killer (NK) cells (Ziegler et al. 1994; Cambiaggi et al. 1992). CD95 (FAS): a type I transmembrane protein, also known as FAS receptor or apoptosis antigen 1. Binding FAS ligand (CD178) induces cell apoptosis which plays a role in the maintenance of the peripheral tolerance. One assumes, that CD95 might be involved in the development of autoimmune diseases. CD95 expression is regulated by $\mathrm{NF}-x \mathrm{~B}$ and is high-regulated in activated T and B cells (Wajant 2002; Liu et al. 2012).

Panel \#3 gives a complementary view of myeloid cells' activation to panel \#2B through the analysis of CD150: also known as signaling lymphocytic activation molecule (SLAM), a type I transmembrane molecule, is expressed by mature dendritic cells and activated monocytes, exclusively after in vitro stimulation by bacteria-derived ligands, and not by cytokine stimulation. The bacteria produce flagellin, a TLR5 activator, which in turn induces CD150 on monocytes (Farina et al. 2004). In MS brain lesion, monocytes do not usually known to express CD150 (Theil et al. 2005).

Panel \#5 completes the B cell and myeloid cells' phenotypes by giving a view of their cytokine secretion phenotype, which could indicate a pro- or anti-inflammatory phenotype. Three major cytokines in MS were analyzed: IL-6: a pro-inflammatory cytokine. IL-6 is an important mediator of fever, achieved through crossing the BBB and initiating $\mathrm{PGE}_{2}$ synthesis in the hypothalamus, changing the body's temperature setpoint, and of the acute phase response, stimulating acute phase protein synthesis such as CRP, as well as the production of neutrophil granulocytes in the bone marrow (Banks et al. 1994; Bastard et al. 1999). TNF- $\alpha$ : a pro-inflammatory cytokine, involved in systemic inflammation, is mainly produced by activated macrophages, but can be produced by other cell population such as lymphocytes, NK cells mast cells and others. TNF- $\alpha$ is an endogenous pyrogen, which induces fever, apoptotic cell death, cachexia and inflammation. IL-10: an anti-inflammatory cytokine, produced mainly by monocytes and, to less extent, by $\mathrm{T}_{\mathrm{H}} 2$ cells, mast cells, $\mathrm{T}_{\text {reg }}$ and certain subsets of activated T and B cells. IL-10 has diverse effects in immunomodulation and inflammation, such as down-regulation of $\mathrm{T}_{\mathrm{H}} 1$ cytokines, $\mathrm{MHC}-\mathrm{II}$ surface antigen and co-stimulatory molecules on macrophages, reducing antigen presentation and $\mathrm{T}$ cell activation. In addition, IL-10 prolongs B cell survival, proliferation, and antibody production (Mosser and Zhang 2008). 


\subsubsection{Stimulation regimes}

Some surface markers and cytokines are up regulated, respectively synthesized only upon cell activation. Therefore, cells were incubated with the following substances to simulate a stimulation. CpG: cytosine triphosphate deoxynucleotide ("C") followed by a guanine triphosphate deoxynucleotide ("G") is unmethylated a frequent DNA sequence in microbial genome, and a rarity in vertebrate genome (Gardiner-Garden and Frommer 1987). As such it is an activator of TLR9 (CD289), which is mostly expressed by B cells and dendritic cells. Once activated, TLR9 is internalized and then activates MyD88, which continues the signaling pathway. TLR9 signal pathway leads to a pro-inflammatory response and to secretion of cytokines such as type-I interferon, IL- 6 , TNF- $\alpha$, IFN- $\alpha$, and IL-12 (RamirezOrtiz et al. 2008; Agrawal and Gupta 2011). LPS: Lipopolysaccharides are large molecules consisting of a lipid and a polysaccharide fraction, which are found in the outer membrane of Gram-negative bacteria (Rothfield and Pearlman-Kothencz 1969). LPS binds the CD14/TLR4/MD2 receptor complex in many cell types, but especially in monocytes, dendritic cells and macrophages, and by doing so activating the signal pathway $\mathrm{NF}-\varkappa \mathrm{B}$, which promotes the secretion of pro-inflammatory cytokines, nitric oxide, and eicosanoids (Underhill and Ozinsky). Ionomycin: an ionophore produced by the bacterium Streptomyces conglobatus. Ionomycin is commonly used to raise the intracellular level of calcium $\left(\mathrm{Ca}^{2+}\right)$ and so to stimulate the intracellular production of various cytokines, such as interferon, perforin, IL-2, and IL-4; usually in conjunction with PMA (Ai et al. 2013). PMA: phorbol 12-myristate 13-acetate, a di-ester of phorbol and a potent tumor promoter often used to activate the signal transduction enzyme protein kinase C (PKC) (Niedel et al. 1983). PMA is also commonly used together with ionomycin to stimulate $\mathrm{T}$-cell activation, proliferation, and cytokine production, and is used in protocols for intracellular staining of these cytokines (Ai et al. 2013). 
The used stimulating regimes are presented in Table 11:

Table 11: Stimulation regimes

\section{Panel}

\#1 B cell subset

\#2 T cell subset

\#2B APC activation

\#3 major immune cell populations

\#4 B cell activation

\#5a cytokine secretion

\#5b cytokine secretion

\#5c cytokine secretion

\#6 CD20+ $\mathrm{T}$ cell subset

\section{Stimulation}

Unstimulated

Unstimulated

Unstimulated

$22 \mathrm{~h}$ with LPS stimulated $[100 \mathrm{pg} / \mathrm{ml}]$

$22 \mathrm{~h}$ with CpG stimulated [ $2 \mu \mathrm{g} / \mathrm{ml}]$

$22 \mathrm{~h}$ with $\mathrm{CpG}$ stimulated

$[1 \mu \mathrm{g} / \mathrm{ml}]$

$20 \mathrm{~h}$ unstimulated

$+2 \mathrm{~h}$ with LPS stimulated

$[500 \mathrm{pg} / \mathrm{ml}]$

$22 \mathrm{~h}$ unstimulated

Unstimulated
+2 h Golgi Plug

+2 h Ionomycin / PMA

$[500 \mathrm{ng} / \mathrm{ml} / 20 \mathrm{ng} / \mathrm{ml}]$

\subsubsection{Sample preparation}

The frozen cells in the cryo-medium were stored at $-80^{\circ} \mathrm{C}$. Due to the fact that the cryo-medium is toxic for living cells, a fast defrost was required, as well as a dilution of the cryo-medium in whole-medium in order to dilute the DMSO, the toxic part. Therefore, the samples were shortly warmed by hand, only until the still frozen sample could be transferred in a tube containing $30 \mathrm{ml}$ whole-medium. In order to properly dilute the cryo-medium no more than three cryo-tubes were defrosted in the same tube. All tubes were centrifuged $\left(1250 \mathrm{rpm}, 4^{\circ} \mathrm{C}, 10\right.$ minutes) and the supernatants were removed. In case more than three cryo-tubes were needed, all cells of the same sample were resuspended in $10 \mathrm{ml}$ whole-medium and transferred into one tube. That tube was again centrifuged and the supernatants were removed. All samples were then resuspended in $1 \mathrm{ml}$ whole-medium, and the cell count was determined.

In order to do so a Neubauer chamber was used. To exclude dead cell from the count, $10 \mu \mathrm{l}$ cell suspension was stained with $10 \mu \mathrm{l}$ TrypanBlue suspension (prediluted 1:10 in PBS), making a dilution factor (dil. fac.) of two. $10 \mu \mathrm{l}$ of that mixture was counted using the counting chamber. The cells in the four $1 \mathrm{~mm}^{2}$ squares were counted, representing a total volume of $0,1 \mu \mathrm{l}$ each, and the mean cells count was calculated. The total cell count of the sample was than calculated as following:

$$
\text { cell count }=\text { mean cells } \cdot 10^{4} \cdot \text { dil.fac. } \cdot \text { volume }[\mathrm{ml}]
$$


The cell suspension was than further diluted with whole-medium to a concentration of 500,000 cells $/ 1 \mathrm{ml}$. $100 \mu \mathrm{l}$ of cell suspension, containing 50,000 cells, was given to a 96 well plate. Unstimulated panels were stained on the same day with a $96 \mathrm{U}$-well plate (panels \#1, 2, 2B), stimulated panels were stimulated in 96 flat-well plate (panels \#3, 4, 5a, $5 \mathrm{~b}, 5 \mathrm{c}$ ), to ensure an equal stimulation. To the stimulated panels \#3, 4, 5a, 5b, 5c were added $100 \mu \mathrm{l}$ of $200 \mathrm{pg} / \mathrm{ml} \mathrm{LPS}, 4 \mu \mathrm{g} / \mathrm{ml} \mathrm{CpG}, 2 \mu \mathrm{g} / \mathrm{ml} \mathrm{CpG}, 80 \mu \mathrm{l}$ whole-medium and $100 \mu \mathrm{l}$ whole-medium respectively, which resulted in a further dilution of the stimulants with the factor two (and so achieving the goal concentrations). The cells were incubated at $37^{\circ} \mathrm{C}$, $5 \% \mathrm{CO}_{2}$ for 22 hours. To panel \#5b $20 \mu \mathrm{l}$ of 5,000 pg/ml LPS were added after 20 hours incubation (after dilution $500 \mathrm{pg} / \mathrm{ml}$ ) and the panel was then further incubated for 2 hours $\left(37^{\circ} \mathrm{C}, 5 \% \mathrm{CO}_{2}\right)$. Panels \#5a, b and c were then further treated as described in 2.3.2.6 below.

After incubation the plates were centrifuged $\left(1250 \mathrm{rpm}, 4^{\circ} \mathrm{C}, 10\right.$ minutes) and the supernatants were frozen at $-20^{\circ} \mathrm{C}$ for a subsequent analysis.

\subsubsection{Dead/Live stain}

In order to exclude dead cells from the analysis, the cells were stained with the fixable Zombie $^{\text {TM }}$ dye (ZombieAqua ${ }^{\text {TM }} /$ ZombieNIR $^{\text {TM }}$ as shown in Tables 8-10, BioLegend). The Zombie $^{\mathrm{TM}}$ dyes react with primary amine groups on proteins. Living cells exclude the dye, resulting only in a surface stain, while dead cells with a compromised cell membrane don't. This result in an entry of the dye into the cytoplasm, and so increasing significantly the amount of stained proteins. Hence dead cells are significantly Zombie ${ }^{\mathrm{TM}}$ brighter than living cells, and can be distinguished (BioLegend).

Prior to staining, the cells were washed twice (resuspension in $170 \mu \mathrm{l}$ PBS followed by centrifugation [1250 $\mathrm{rpm}, 4^{\circ} \mathrm{C}, 7 \mathrm{~min}$ ] and remove of supernatants, wash in PBS). Afterwards $30 \mu \mathrm{l}$ of the compatible Zombie ${ }^{\mathrm{TM}}$ dye (1:500 in PBS) were given into the sample wells and the Zombie ${ }^{\mathrm{TM}}$ single staining, followed by 10 minutes at room temperature incubation in the dark. Followed the cells were washed in FACS buffer.

\subsubsection{Fc-block}

Some immune cell populations bear Fc receptors on their surface, which may falsely bind and lead to non-specific staining of the antibodies. Therefore, a blockage of those Fc receptors was required in order to ensure a specific and accurate stain. After washing all cells were incubated with $30 \mu \mathrm{Fc}-B \operatorname{lock}^{\mathrm{TM}}$ ( $50 \mu \mathrm{g} / \mathrm{ml}$ in FACS buffer) for 10 minutes on ice in the dark. After incubation the cells were washed in FACS buffer.

\subsubsection{Surface stain}

Before the surface stain can be performed, several preparations were required. The samples needed to be stained with all fluorophore labelled antibodies, whether the single staining samples only with one, in order to create a compensation. Therefore an "antibodies-mix" 
containing all fluorophore labelled antibodies of a panel (diluted 1:100 in FACS buffer), as well as single antibody solutions (1:100 in FACS buffer) for the single stainings needed to be made. Samples were given with $30 \mu$ of antibody-mix, single stainings with $30 \mu$ l of the single antibody solutions, and incubated for 10 minutes on ice in the dark. After incubation, the cells were washed in FACS buffer twice and then resuspended in $100 \mu \mathrm{l}$ FACS buffer for transfer into $5 \mathrm{ml} \mathrm{FACS}$ tubes for the flow cytometry analysis.

\subsubsection{Intracellular stain}

In order to ensure a proper cytokine accumulation in the cells that can be stained and furthermore detected, the Golgi apparatus needs to be stopped. Therefore, $10 \mu$ GolgiPlug $^{\mathrm{TM}}$ (pre-diluted 1:10 in whole-medium) were added to the "cytokine secretion" panels (panels \#5a, b, c) after stimulation, followed by a two hours incubation $\left(37^{\circ} \mathrm{C}, 5 \% \mathrm{CO}_{2}\right)$. To further increase the cytokine synthesis $50 \mu \mathrm{l}$ Ionomycin [3000 ng/ml] and $50 \mu \mathrm{l}$ PMA [300 ng/ml] were added [500 $\mathrm{ng} / \mathrm{ml}$ respectively $20 \mathrm{ng} / \mathrm{ml}$ after in well dilution] and incubated for two more hours $\left(37^{\circ} \mathrm{C}, 5 \% \mathrm{CO}_{2}\right)$. After incubation the cells were centrifuged $\left(1250 \mathrm{rpm}, 4^{\circ} \mathrm{C}\right.$, 10 minutes) and the supernatants were frozen at $-20^{\circ} \mathrm{C}$ for a subsequent analysis. The cells to be stained were resuspended in PBS and a surface stain as described in 2.3.2.3 above was performed.

To perform an intracellular stain of the cells, the cell membrane needed to be fixed and permeabilized, achieved by adding $50 \mu \mathrm{Fix} /$ Perm $^{\text {TM }}$ to each well followed by a 30 minutes incubation in room temperature in the dark. Afterwards the cells were washed in $200 \mu \mathrm{l}$ Perm/Wash ${ }^{\mathrm{TM}}$ (prediluted 1:10 in $\mathrm{ddH}_{2} \mathrm{O}$ ) and then given $50 \mu \mathrm{l}$ of prepared intracellular fluorophore labelled antibody-mix respectively single antibody solutions (1:50 in Perm/Wash ${ }^{\mathrm{TM}}$; as explained in 2.3.2.5 above). The cells were then incubated with the antibodies for 16 hours at $4^{\circ} \mathrm{C}$ covered with aluminum foil. On the next day the cells were wash in FACS buffer twice, resuspended in $100 \mu$ FACS buffer, transferred into a $5 \mathrm{ml} \mathrm{FACS}$ tube and analyzed.

\subsubsection{Flow cytometry and gating strategy}

The fluorophore-labelled stained cells were analyzed by flow cytometry using the LSRII Fortressa FACS machine (manufacturer: BD Biosciences). To ensure accurate and reliable results all samples were stained in duplicates. Each sample was acquired for 75 seconds (time required for $100 \mu \mathrm{l}$ sample to be fully acquired). Due to the large number of samples, they could not be processed and measured at the same time, though all samples of the same patient were always analyzed at the same time. In every repetition the PBMCs of the same healthy control were also analyzed, to ensure the stain's successfulness, and to analyze all samples similarly. The cells for the single stainings of the fluorophores also came from the healthy control. Even though all stains were performed identically, minor changes could not be avoided (such as antibody residue on the pipette end, causing a slightly brighter 
fluorescence for example), which resulted in a slightly different compensation. In order not to neglect these minor differences, but rather address them, every stain was analyzed with its compensation and gated with its control.

The data obtained was analyzed using the FlowJo ${ }^{\text {TM }}$ 10.5.3.

In order to identify the living cells in the sample, pre-gating was performed in all panels as shown in Figure 3A. Only those cells were then analyzed according to the goals of the panel. For some surface markers are ubiquitous expressed by all cells of a population, the mean fluorescence intensity (MFI) was used to semi quantify their expression, as shown in Figure 3B.
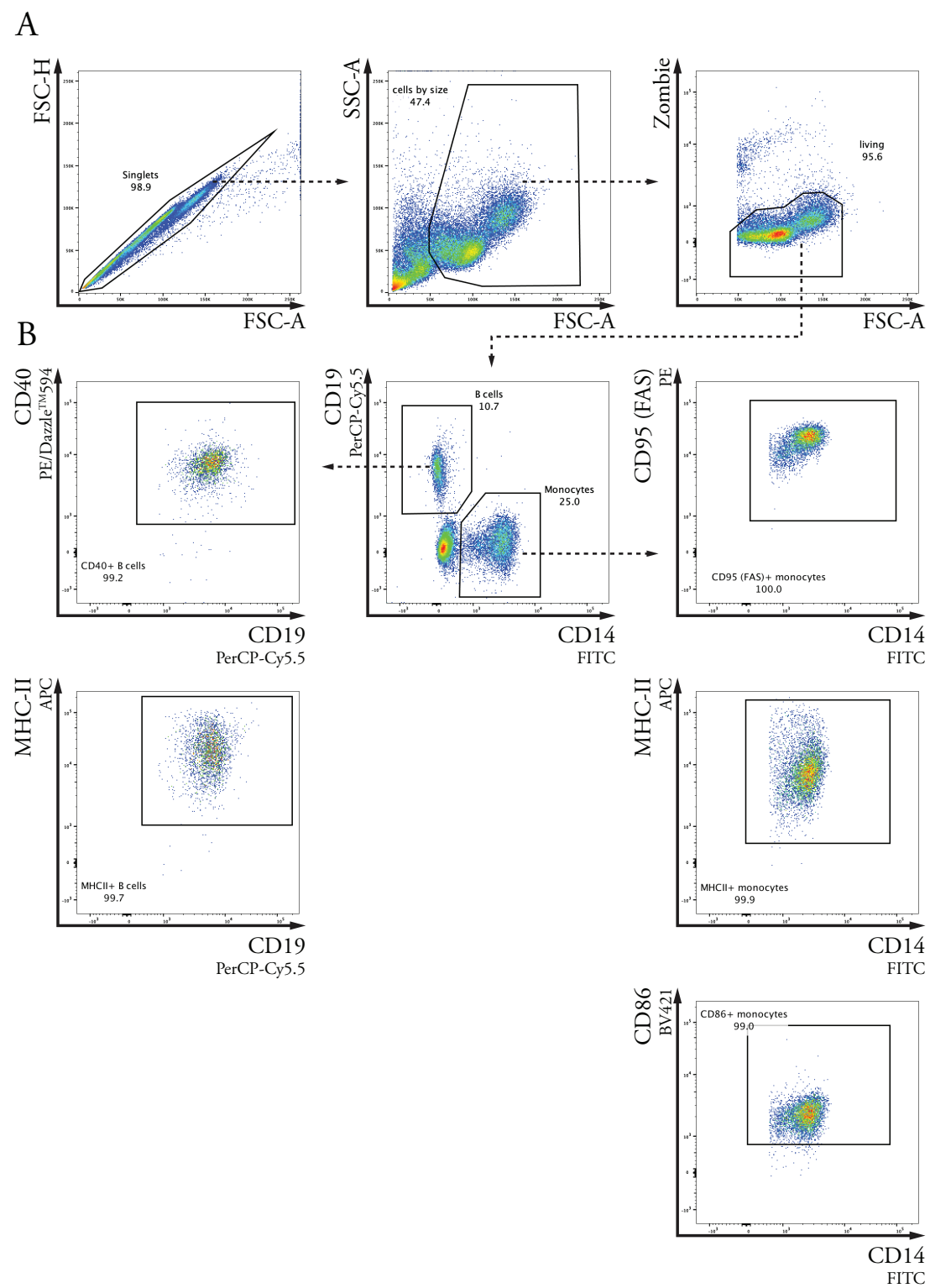

Figure 3. Gating strategy. The figure shows the three pre-gates that proceeded to every analysis (A) and a few examples of ubiquitous expressed surface antigens (B). 


\subsubsection{TBNK classification}

The TBNK classification is a flow cytometry-based analysis of not agglutinated whole blood samples (EDTA blood). This classification was performed by the central laboratory of the University Medical Centre in Göttingen Germany. The certificate of the laboratory for this analysis is attached in supplements (see 6.1 below).

\subsubsection{Statistical analysis}

GraphPad Prism ${ }^{\mathrm{TM}} 7 \mathrm{a}$ was used for all statistical analysis. The patients' data were tested for Gauss distribution with the Shapiro-Wilk normality test and the Kolmogorov-Smirnov normality test. Data were analyzed as Gauss distributed when both tests were positive. For two longitudinal samples with Gauss distribution the paired t-test was used, without Gauss distribution the Wilcoxon matched-pairs signed rank test. As not all patients had samples for all time points, an ANOVA could not be performed. Therefore, paired t-tests respectively Wilcoxon matched-pairs signed rank tests were used and the $\alpha$-value was corrected with the Bonferroni-Holm method. For possible correlations linear regression was used, for interval scale Spearman $r$, for rational scale Pearson $r$. A p-value $<0.05$ was considered statistically significant, and $\mathrm{p}<0.05^{(*)}, \mathrm{p}<0.005^{(* *)}, \mathrm{p}<0.0005^{(* *)}, \mathrm{p}<0.0001^{(* * *)}$, were defined. 


\section{Results}

\subsection{Direct effects of anti-CD20 depletion on $\mathrm{CD} 20^{+} \mathrm{B}$ and $\mathrm{T}$ cells}

\subsubsection{Effects on B cells}

$\mathrm{B}$ cells are the target of anti-CD20 depletion, and the effects of their elimination were of great interest in this project. Therefore, it was necessary to ensure that the B cells were successfully eliminated. Figure 4 shows the B cell frequencies and counts in four time points for every patient (for differences between early and late repletion see 3.1.2 below). The figure shows, that the B cells, starting at a mean frequency of 10\% and mean counts of 154 cells per $\mu \mathrm{l}$ blood before depletion, are successfully depleted at the "depletion" time point, and first reappear at the "late repletion" time point. A sample was considered repleted, when the $\mathrm{CD}_{1}{ }^{+}$cell frequency of all living PBMCs was greater than $1 \%$.

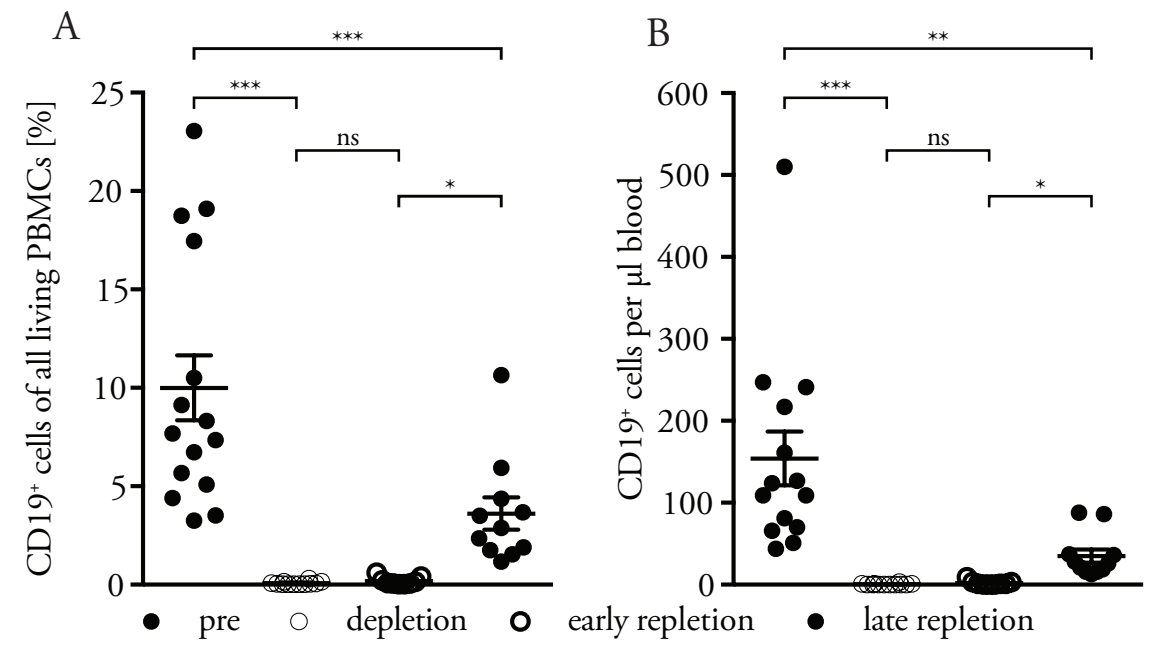

Figure 4. B cell frequency and cell count. The figure shows the frequencies of CD19+ cells expressed as \% of all living PBMCs unstimulated (A) and the B cell counts determined in a TBNK classification of whole blood (B) in four time points for every patient. Data is presented as mean \pm standard error of mean ( $n=15 / 12 / 10 / 10$; Wilcoxon matched-pairs signed rank test as stated in figure).

In order to further characterize the possible changes in the $\mathrm{B}$ cell maturation phenotype upon repletion, five main B cell maturation phases described in 1.1.4.2 above and shown in Figure 5 were analyzed before $\mathrm{B}$ cell depletion and during late repletion. The figure shows a shift in the B cell maturation phenotype. Before B cell depletion, peripheral B cells were mainly mature naïve and memory B cells. During late repletion this phenotype changes, and the majority of B cells are transitional and naïve B cells making together a total of $83.96 \%$ of all $\mathrm{B}$ cells. This reflects the migration of new maturating cells from the bone marrow into the peripheral blood. The plasmablasts' frequency is slightly elevated, since these cells are not depleted after anti-CD20 treatment. 


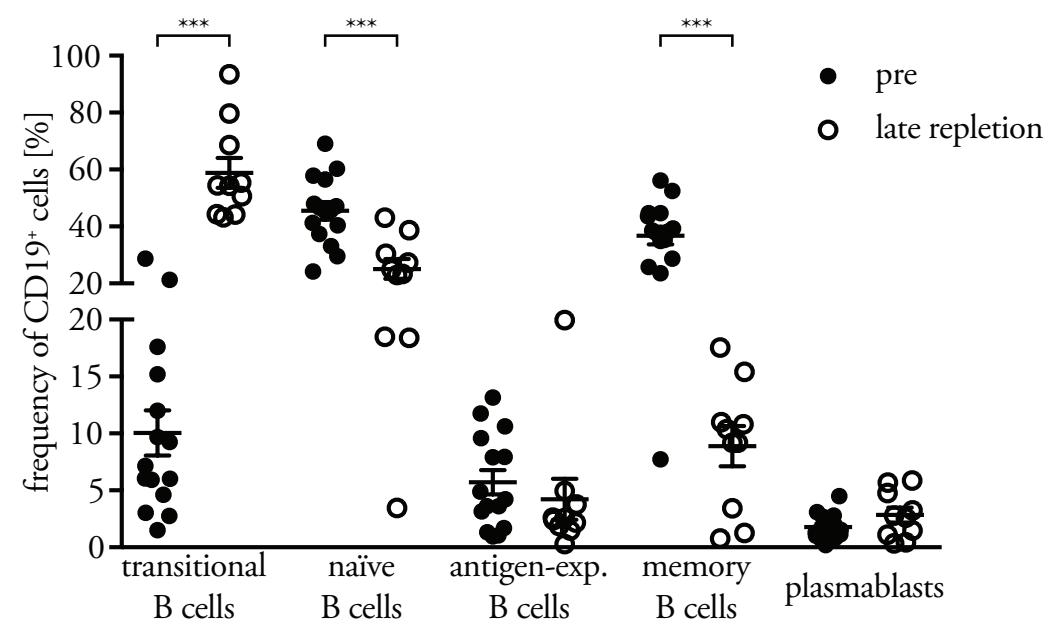

Figure 5. B cell maturation phenotype. The figure shows the frequencies of transitional, naïve, activated, memory B cells and plasmablasts expressed as \% of CD19+ cells before B cell depletion and during late repletion. Data is presented as mean \pm standard error of mean ( $\mathrm{n}=15 / 10$; paired $\mathrm{t}$-test/Wilcoxon matched-pairs signed rank test: ns unless otherwise stated).

As for the B cell activation phenotype, three key surface antigens were analyzed. As shown in Figure 6, the frequencies of $\mathrm{CD} 25^{+}, \mathrm{CD} 69^{+}$and $\mathrm{CD} 95(\mathrm{FAS})^{+} \mathrm{B}$ cells is significantly higher during late repletion than before therapy administration, indicating a more activated phenotype of the transitional and naïve B cells, the two major B cell populations at late repletion.

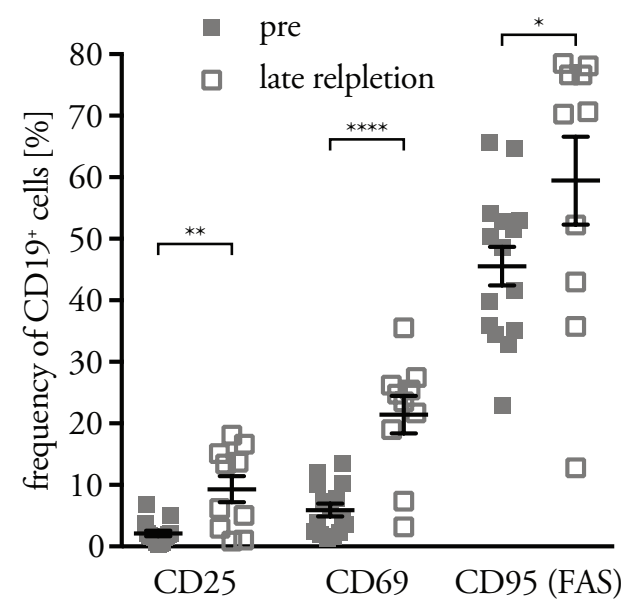

Figure 6. B cell activation phenotype. The figure shows the frequencies of $\mathrm{CD} 25^{+}, \mathrm{CD}^{+} 9^{+}$, and CD $95(\mathrm{FAS})^{+}$expressed as \% of $\mathrm{CD} 19^{+} \mathrm{B}$ cells upon $\mathrm{CPG}$ stimulation $[2 \mu \mathrm{g} / \mathrm{ml}]$ before B cell depletion and during late repletion. Data is presented as mean \pm standard error of mean ( $\mathrm{n}=15 / 10$; paired t-test/Wilcoxon matched-pairs signed rank test: ns unless otherwise stated).

As B cells are professional APCs, their antigen presentation phenotype was analyzed. As shown in Figure 7, there seems to be a non-significant decrease in $\mathrm{CD}^{+} 0^{+}$cells, however significantly more $\mathrm{CD} 86^{+} \mathrm{B}$ cells were seen. The MFI of CD40 was slightly, yet significantly elevated, the MFI of MHC-II remained stable. 

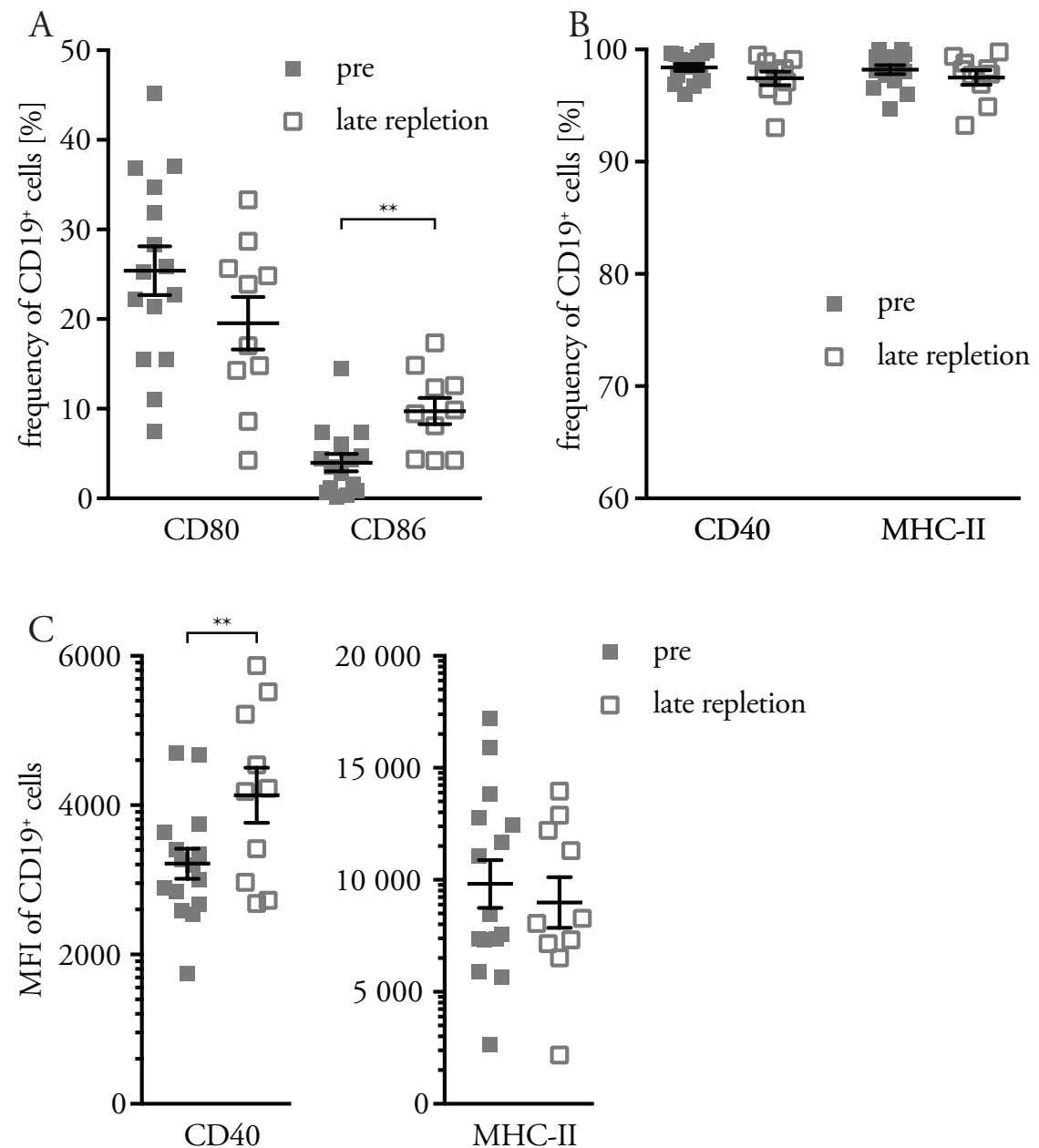

pre

$\square$ late repletion

Figure 7. B cell APC phenotype. The figure shows the frequencies of (A) $\mathrm{CD} 80^{+}, \mathrm{CD}_{8} 6^{+}$and $(\mathrm{B})$ $\mathrm{CD}_{40}{ }^{+}$and MHC-II ${ }^{+}$expressed as \% of CD19+ $\mathrm{B}$ cells and the (C) MFIs of CD40 and MHC-II of CD19+ B cells upon CpG stimulation $[2 \mu \mathrm{g} / \mathrm{ml}]$ before B cell depletion and during late repletion. Data is presented as mean \pm standard error of mean ( $n=15 / 10$; paired $t$-test: $n s$ unless otherwise stated).

The B cell expression of the surface antigens CD40, CD80, CD86, CD95 (FAS) and MHC-II was also analyzed unstimulated in panel \#2B, an analysis which has shown similar differences as the results shown in Figures 6 and 7, and therefore are not shown here.

B cells have an immunomodulatory function, which they fulfil via cytokine secretion. IL-6, IL-10 and TNF- $\alpha$ are three of the cytokines that are known to have a key role in the pathogenesis of MS. The unstimulated B cell cytokine phenotype, as shown in Figure 8, shows a significant elevation in IL-6 production, a non-significant decrease in TNF- $\alpha$ production, and almost non-IL-10 production. 

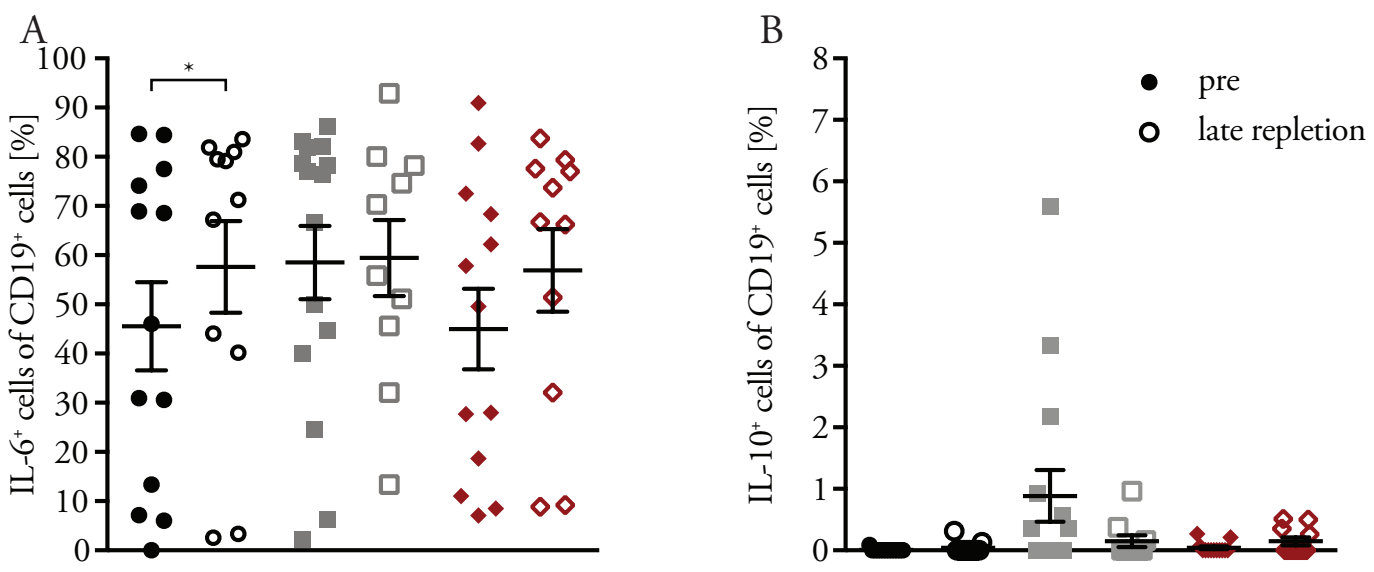

- unstimulated

- CpG stimulated

- LPS stimulated

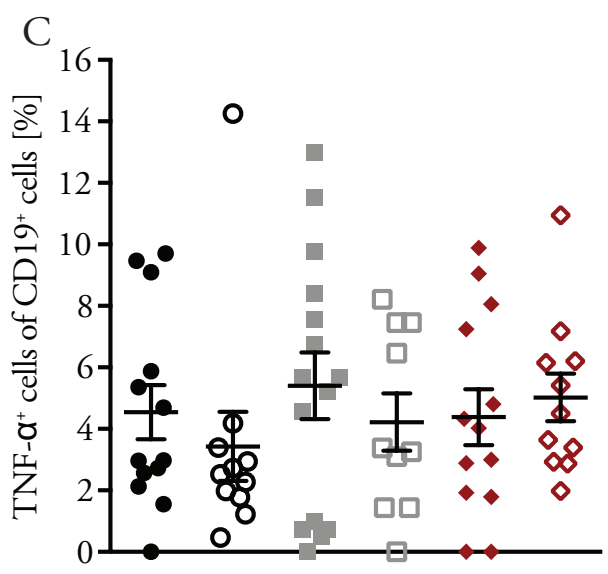

Figure 8. B cell cytokine phenotype. The figure shows the frequencies of IL- $6^{+}(\mathrm{A}), \mathrm{IL}-10^{+}$(B) and TNF- $\alpha^{+}(\mathrm{C})$ cells expressed as \% of $\mathrm{CD}_{1}{ }^{+} \mathrm{B}$ cells unstimulated, upon $\mathrm{CpG}[1 \mu \mathrm{g} / \mathrm{ml}]$ and LPS $[500 \mathrm{pg} / \mathrm{ml}]$ stimulation as shown in Table 11 before $\mathrm{B}$ cell depletion and during late repletion. Data is presented as mean \pm standard error of mean $(n=15 / 10$; paired t-test/Wilcoxon matched-pairs signed rank test: ns unless otherwise stated). 


\subsubsection{Effects on $\mathrm{CD}^{2}{ }^{+} \mathrm{T}$ cells}

$\mathrm{T}$ cells may express CD20, and therefore may be depleted after administration of anti-CD20-mAb. To characterize possible depletion and repletion of CD20 $0^{+} \mathrm{T}$ cells and its kinetics, their frequencies were analyzed. The $\mathrm{CD} 20^{+} \mathrm{T}$ cells replete earlier than the $\mathrm{B}$ cells. Figure 9 shows the four immunological states of the patients' samples. When comparing before therapy and at late repletion, the ratio between the frequencies of $\mathrm{CD}_{2} 0^{+} \mathrm{T}_{\mathrm{H}}, \mathrm{T}_{\mathrm{C}}$ and $B$ cells is the same, all patients have very few $C D 20^{+} T_{H}$ cells, followed by $C D 20^{+} T_{C}$ cells (as they are a small subpopulation) and B cells. At depletion all three cell populations show a successful depletion. When comparing the differences at depletion and at early repletion, one could see a significant increase in $\mathrm{CD} 20^{+} \mathrm{T}_{\mathrm{C}}$ cell frequency, a (after Bonferroni-Holm correction as stated in legend) non-significant increase in $\mathrm{CD} 20^{+} \mathrm{T}_{\mathrm{H}}$ cell frequency, and a non-significant minor increase in $\mathrm{B}$ cell frequency, indicating the repletion of the $\mathrm{CD} 20^{+} \mathrm{T}$ cells but not of the B cells.

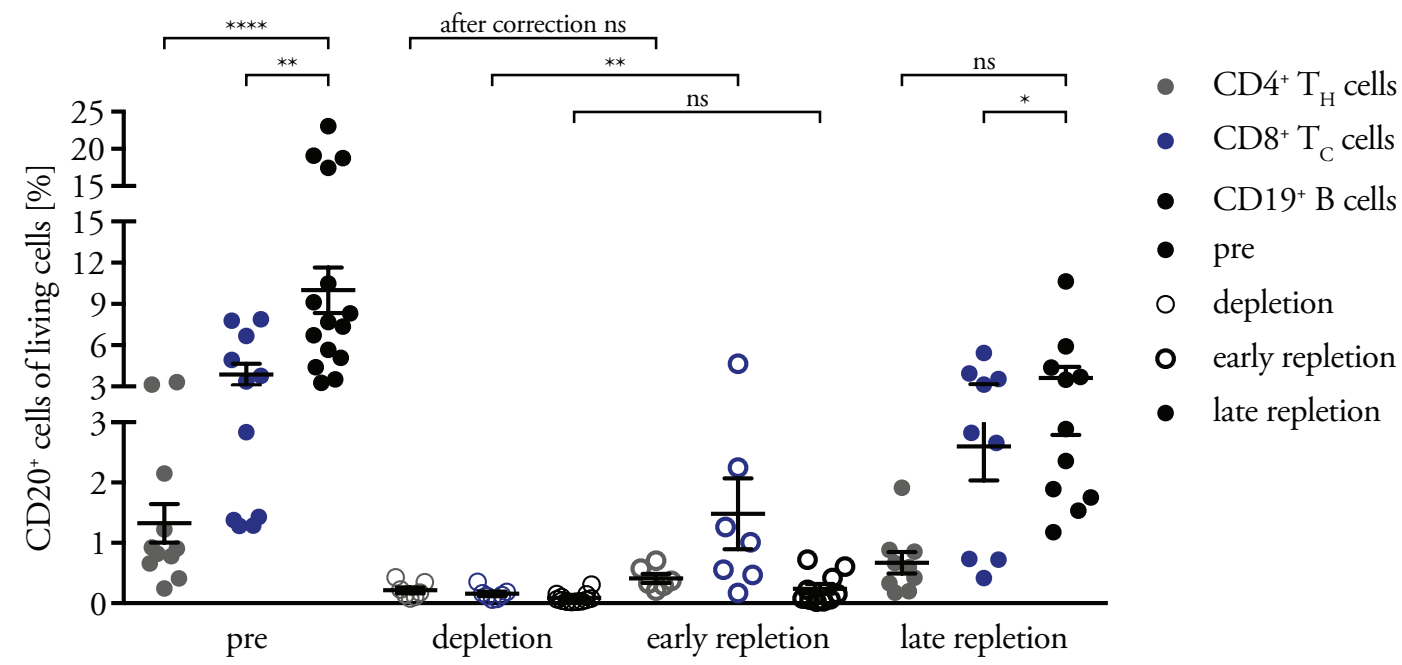

Figure 9. Overview of $\mathrm{CD} 20^{+}$cells population. The figure shows the frequency of $\mathrm{CD} 20^{+}$cell population expressed as \% of all living PBMCs before anti-CD20 therapy (left), at depletion ( $2^{\text {nd }}$ from left), at early, $\mathrm{CD} 20^{+} \mathrm{T}$ cell, repletion ( $2^{\text {nd }}$ from right) and at late, $\mathrm{B}$ cell, repletion (right). Data is presented as mean \pm standard error of mean ( $\mathrm{n}=11,11,15 / 7,7,12 / 7,7,10 / 9,9,11$; Wilcoxon matched-pairs signed rank test/Mann-Whitney-U-Test as stated in figure; $\mathrm{CD}_{4}{ }^{+}$depletion-early repletion $\mathrm{p}=0.0379$, after Bonferroni-Holm correction: $\mathrm{ns}$ ).

Figure 10 shows the frequencies of $\mathrm{CD} 20^{+} \mathrm{T}$ cells in four time points for every patient. One could see, that the CD $20^{+} \mathrm{T}$ cells, starting at mean frequency of $9 \%$ (all T cells) $5.8 \%$ (CD $4^{+}$) and $16.3 \%\left(\mathrm{CD}^{+}\right)$are successfully depleted at the "depletion" time point, and start to replete at the time point "early repletion", with a mean frequency of $2.85 \%$ (all T cells) $1.16 \%\left(\mathrm{CD} 4^{+}\right.$) and $4.6 \%\left(\mathrm{CD}^{+}\right)$whereas the $\mathrm{B}$ cells, as shown in Figure 4 , do not yet replete at that timepoint. A sample was considered repleted, when the $\mathrm{CD} 20^{+}$cell frequency of $\mathrm{CD}^{+}$ respectively $\mathrm{CD} 8^{+}$cells was greater than $1 \%$. 

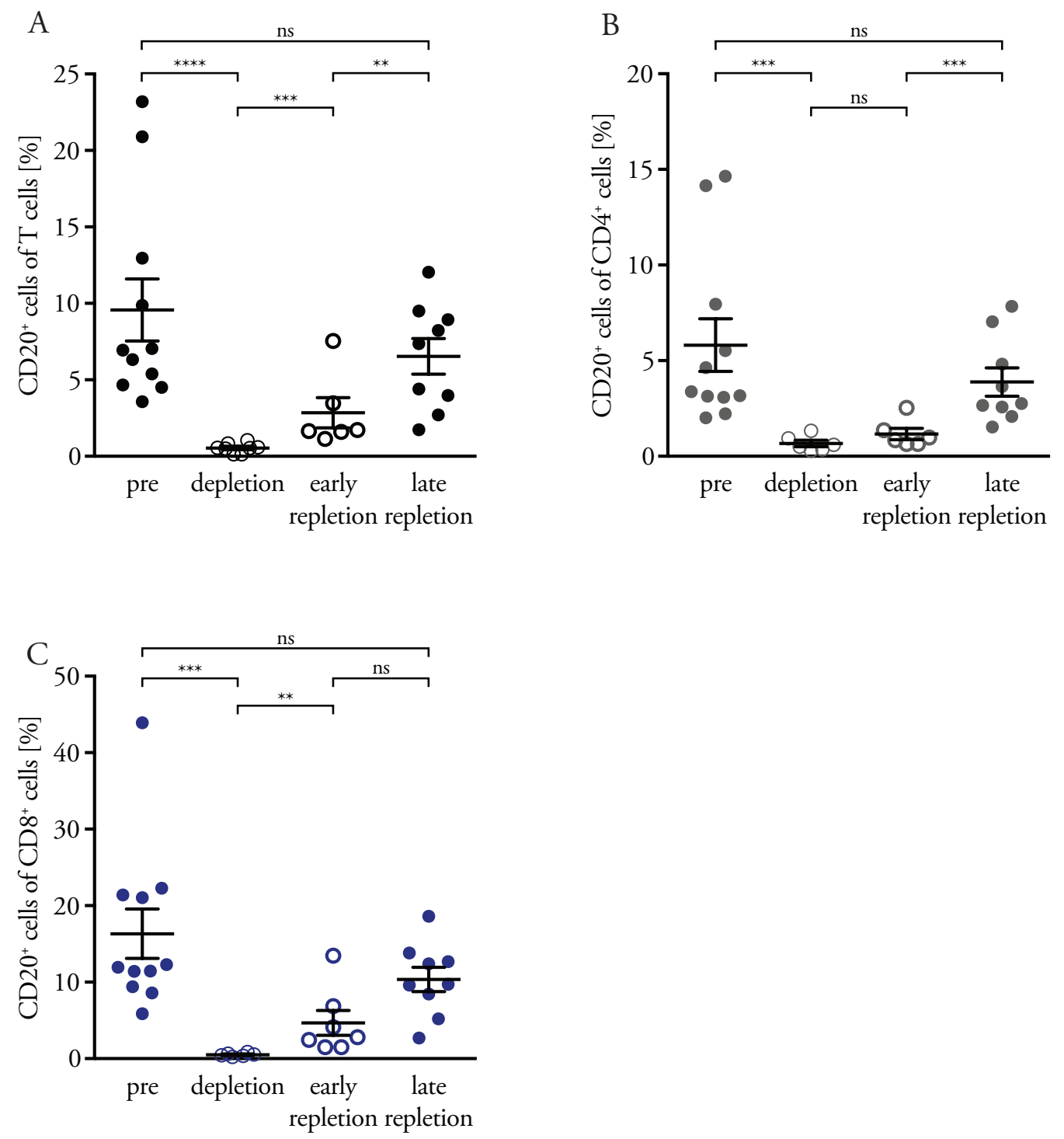

Figure 10. $\mathrm{CD} 20^{+} \mathrm{T}$ cells frequencies. The figure shows the frequencies of $\mathrm{CD} 20^{+}$cells expressed as $\%$ of all $\mathrm{T}$ cells (A) $\mathrm{CD}^{+}{ }^{+} \mathrm{T}_{\mathrm{H}}$ cells (B) and of $\mathrm{CD}^{+}{ }^{+} \mathrm{T}_{\mathrm{C}}$ cells $(\mathrm{C})$ in four time points for every patient. Data is presented as mean \pm standard error of mean $(n=11 / 6 / 7 / 9$; Mann-Whitney-U-Test as stated in figure).

After observing that, the time difference between the repletion phases was of interest. Figure 11 shows the time difference between detection of repleting $\mathrm{CD}_{2} 0^{+} \mathrm{T}$ cells ( = early repletion), after a mean time of 191.81 days, compared to repleting CD20 $0^{+}$B cells ( = late repletion), that occurred after a mean time of 309.09 days. One could see through the lines connecting every patient's date, that the $\mathrm{CD} 20^{+} \mathrm{T}$ cells replete earlier than the $\mathrm{CD} 20^{+} \mathrm{B}$ cells individually for every patient. 


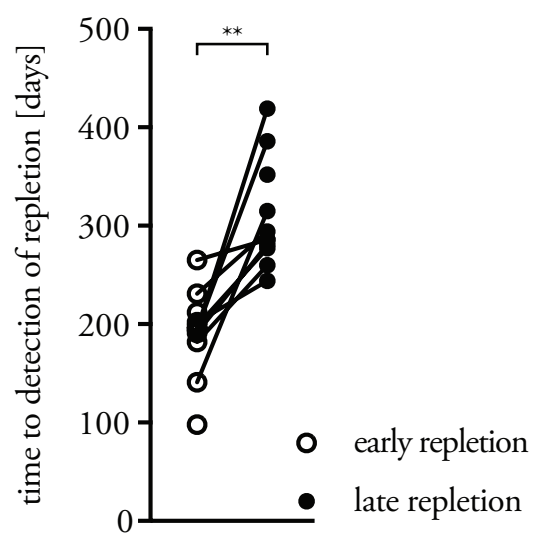

Figure 11. Time to detection of $\mathrm{CD} 20^{+}$cells' repletion. The figure shows the time in days past between last anti-CD20 therapy administration and the detection of $\mathrm{CD} 20^{+}$cells at early and late repletion phases. ( $\mathrm{n}=9$, paired $\mathrm{t}$-test).

As shown in Figure 10, the $\mathrm{T}_{\mathrm{C}}$ cells express more CD20 than $\mathrm{T}_{\mathrm{H}}$ cells, the $\mathrm{T} 4 / \mathrm{T} 8$ ratio (ratio between the frequencies of $\mathrm{CD}^{+} \mathrm{T}_{\mathrm{H}}$ and $\mathrm{CD} 8^{+} \mathrm{T}_{\mathrm{C}}$ of $\mathrm{CD} 20^{+}$respectively $\mathrm{CD} 20^{-}$of all living PBMCs) was also analyzed before the administration of anti-CD20 therapy. Figure 12A presents the frequencies of $\mathrm{CD} 4^{+}$respectively $\mathrm{CD} 8^{+}$cells of $\mathrm{CD} 20^{+}$and of $\mathrm{CD} 20^{-} \mathrm{T}$ cells, and shows that among the CD20- $\mathrm{T}$ cells, the frequencies of $\mathrm{CD} 4^{+} \mathrm{T}_{\mathrm{H}}$ and $\mathrm{CD} 8^{+} \mathrm{T}_{\mathrm{C}}$ cells are largely the same, explaining the mean ratio of 1 (the distribution of the ratios in Figure 12B shows that the frequencies within the $\mathrm{CD}^{-} 0^{-}$cells compartment also varyies, but as shown in figure non-significant). On the other hand, the figure shows that the frequency of $\mathrm{CD} 8^{+} \mathrm{T}_{\mathrm{C}}$ calls among the $\mathrm{CD} 20^{+} \mathrm{T}$ cell compartment is almost double than the frequency of the $\mathrm{CD} 4^{+} \mathrm{T}_{\mathrm{H}}$ cells within this compartment, explaining the ratio of 0.5 .

A

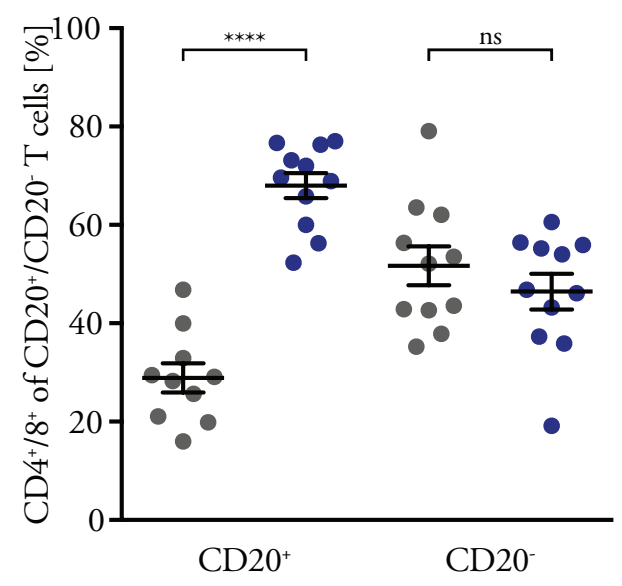

B

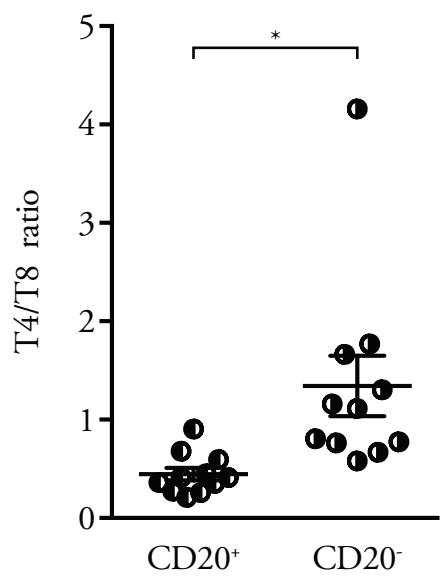

- $\mathrm{CD}^{+} \mathrm{T}_{\mathrm{H}}$ cells $-\mathrm{CD}^{+} \mathrm{T}_{\mathrm{C}}$ cells

Figure 12. T4/T8 ratio. The figure shows the (A) frequencies of $\mathrm{CD}^{+} \mathrm{T}_{\mathrm{H}}$ and $\mathrm{CD} 8{ }^{+} \mathrm{T}_{\mathrm{C}}$ cells within the $\mathrm{CD} 20^{+}$and $\mathrm{CD} 20^{-} \mathrm{T}$ cell compartment before administration of anti-CD20 therapy expressed as $\%$ of all $\mathrm{T}$ cells. The figure also shows the (B) T4/T8 ratio among the $\mathrm{T}$ cells in the compartment. Data is presented as mean \pm standard error of mean ( $n=11$; paired t-test as stated in figure). 
Furthermore, the detailed characterization of the $\mathrm{CD} 20^{+} \mathrm{T}$ cells maturation phases (naive and memory) and the CD25 expression was analyzed. The CD25 expression of the $\mathrm{CD} 20^{+} \mathrm{T}$ cells did not differ from its expression among the CD20- $\mathrm{T}$ cells (data not shown).

Figure 13 shows the two maturation phases of the $\mathrm{CD} 20^{+} \mathrm{CD} 4^{+} \mathrm{T}_{\mathrm{H}}$ cells and their CD25 expression. Most CD20 ${ }^{+} \mathrm{T}_{\mathrm{H}}$ cells were memory $\mathrm{T}$ cells before depletion and at early and late repletion. Their frequency slightly decreases at early repletion and increases at late repletion, all non-significant. The frequency of naïve $\mathrm{CD} 20^{+} \mathrm{T}_{\mathrm{H}}$ cells, expressing CD45RA, remains mostly stable during the three time points. It increases at early repletion, and stays constant at late repletion, all non-significant. The CD25 expression of these cells remains constant through all time points (besides one patient).

A

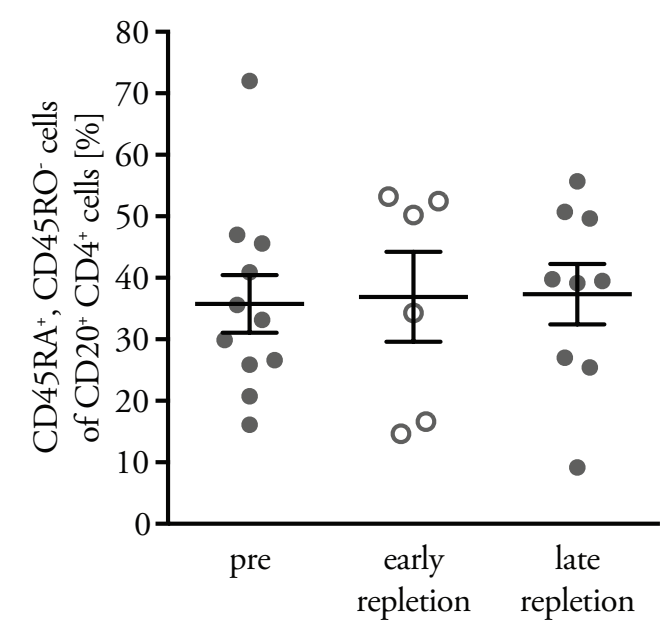

C

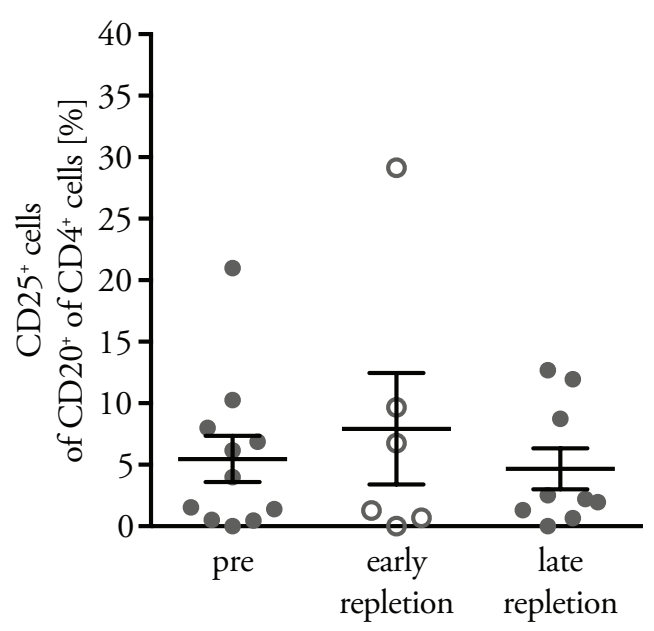

$\mathrm{B}$

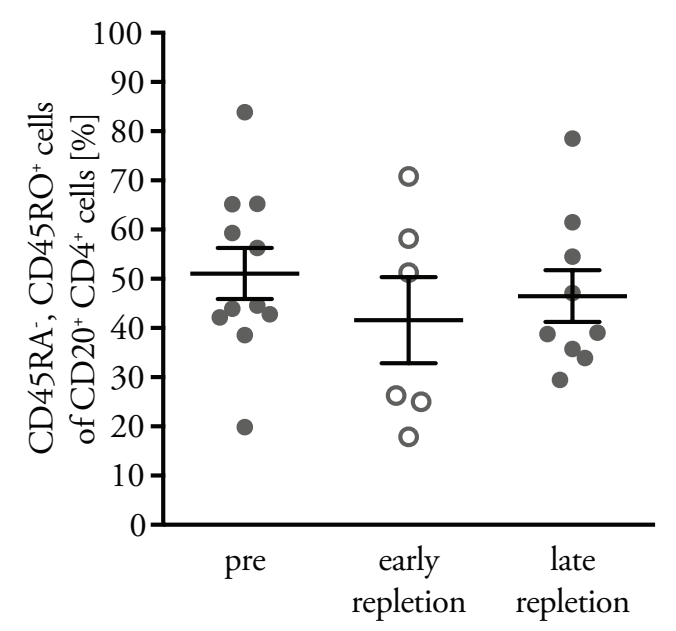

Figure 13. $\mathrm{CD} 20^{+} \mathrm{CD} 4{ }^{+} \mathrm{T}_{\mathrm{H}}$ cells maturation and $\mathrm{CD} 25$ expression phenotype. The figure shows the frequencies of naïve (A) and memory (B) $\mathrm{CD} 20^{+} \mathrm{T}_{\mathrm{H}}$ cells expressed as $\%$ of $\mathrm{CD} 20^{+} \mathrm{CD} 4{ }^{+}$cells as well as the $\mathrm{CD}_{25} 5^{+}$(C) $\mathrm{CD} 20^{+} \mathrm{T}_{\mathrm{H}}$ cells expressed as \% of $\mathrm{CD} 20^{+} \mathrm{CD} 4{ }^{+}$cells through three time points for every patient. Data is presented as mean \pm standard error of mean ( $n=11 / 6 / 9$; paired t-test/Wilcoxon matched-pairs signed rank test: ns unless otherwise stated). 
Figure 14 shows the three maturation phases of the $\mathrm{CD} 20^{+} \mathrm{CD} 8^{+} \mathrm{T}_{\mathrm{C}}$ cells and their CD25 expression. Most CD $20^{+} \mathrm{T}_{\mathrm{C}}$ cells were naïve before depletion and at early and late repletion. The transient $\mathrm{CD} 20^{+} \mathrm{T}_{\mathrm{C}}$ cells, expressing both CD45RA and CD45RO, remain through all time points constant at approx. $22 \%$. On the other hand, the frequency of memory CD $20^{+} \mathrm{T}_{\mathrm{C}}$ cells, expressing CD45RO, increases non-significantly at early repletion, and then significantly decreases at late repletion. The CD25 expression of these cells remains constant through all time points (besides one patient, but not the same one as in Figure 13).

A

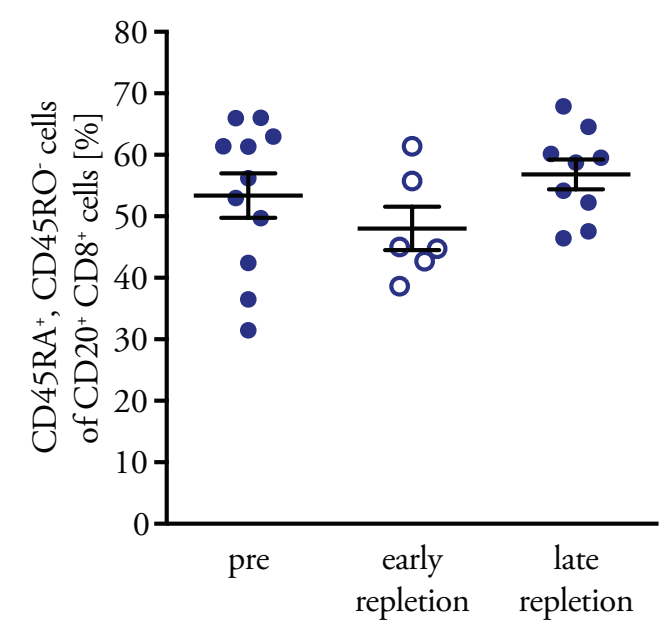

C

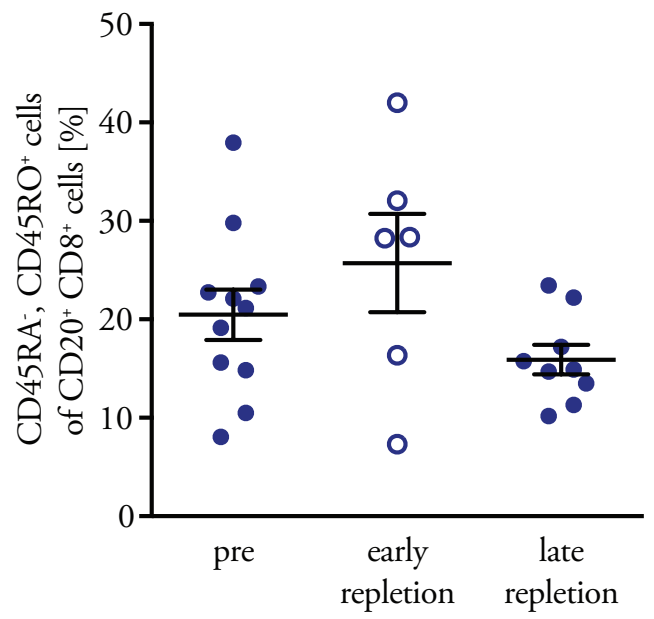

B

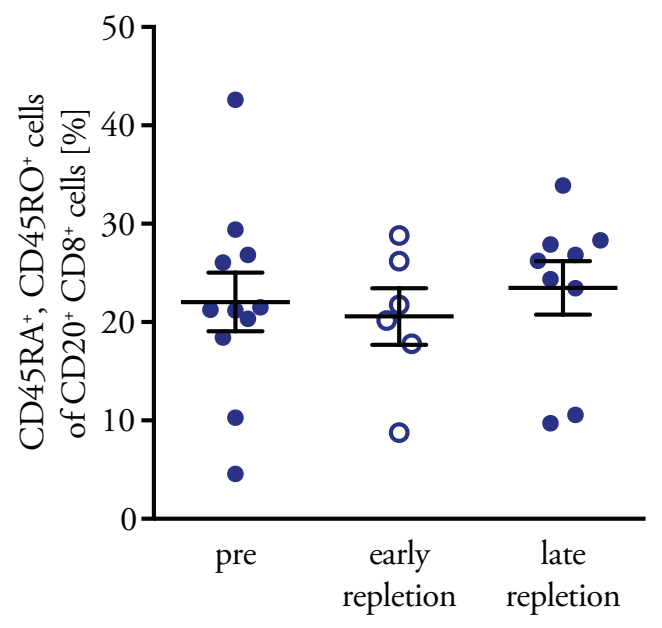

$\mathrm{D}$

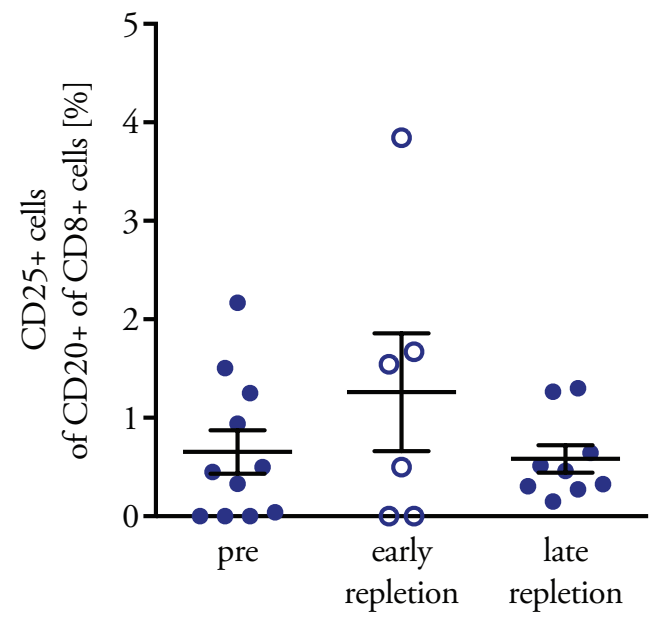

Figure 14. $\mathrm{CD} 20+\mathrm{CD} 8+\mathrm{T}_{\mathrm{C}}$ cells maturation and $\mathrm{CD} 25$ expression phenotype. The figure shows the frequencies of naïve (A), transient (B) and memory (C) CD20 ${ }^{+} \mathrm{T}_{\mathrm{C}}$ cells expressed as \% of $\mathrm{CD} 20^{+} \mathrm{CD} 8{ }^{+}$cells as well as the $\mathrm{CD} 25^{+}$(D) $\mathrm{CD} 20^{+} \mathrm{T}_{\mathrm{C}}$ cells expressed as $\%$ of $\mathrm{CD} 20^{+} \mathrm{CD} 8{ }^{+}$cells through three time points for every patient. Data is presented as mean \pm standard error of mean ( $n=11 / 6 / 9$; paired t-test/Wilcoxon matched-pairs signed rank test: ns unless otherwise stated). 


\subsection{Indirect effects on other immune cell populations}

\subsubsection{Effects on $\mathrm{CD}^{-}{ }^{-} \mathrm{T}$ cells}

As they play different roles in the immune reaction and interact differently with $\mathrm{B}$ cells, it is necessary to differentiate between $\mathrm{CD} 4^{+} \mathrm{T}_{\mathrm{H}}$ cells and $\mathrm{CD} 8^{+} \mathrm{T}_{\mathrm{C}}$ cells.

\subsubsection{Effects on $\mathrm{CD}^{+}{ }^{+} \mathrm{T}_{\mathrm{H}}$ helper cells}

In the classical EAE model of MS, the disease is driven by autoreactive $\mathrm{CD} 4^{+} \mathrm{T}_{\mathrm{H}}$ cells. Therefore, it was of great interest to examine the influence of anti-CD20 therapy on this immune population. Figure 15 shows the $\mathrm{CD}^{+}{ }^{+} \mathrm{T}_{\mathrm{H}}$ cells' frequencies and cell counts in the four time points for every patient. One could see a significant increase in the frequency of $\mathrm{T}_{\mathrm{H}}$ cells at depletion, representing the loss of $\mathrm{CD} 20^{+}$cells, which then normalizes, reflecting the $\mathrm{CD} 20^{+}$cell depletion and the successive repletion of $\mathrm{CD} 20^{+} \mathrm{T}$ cells and of $\mathrm{B}$ cells. On the other hand, the cell count hardly changes.
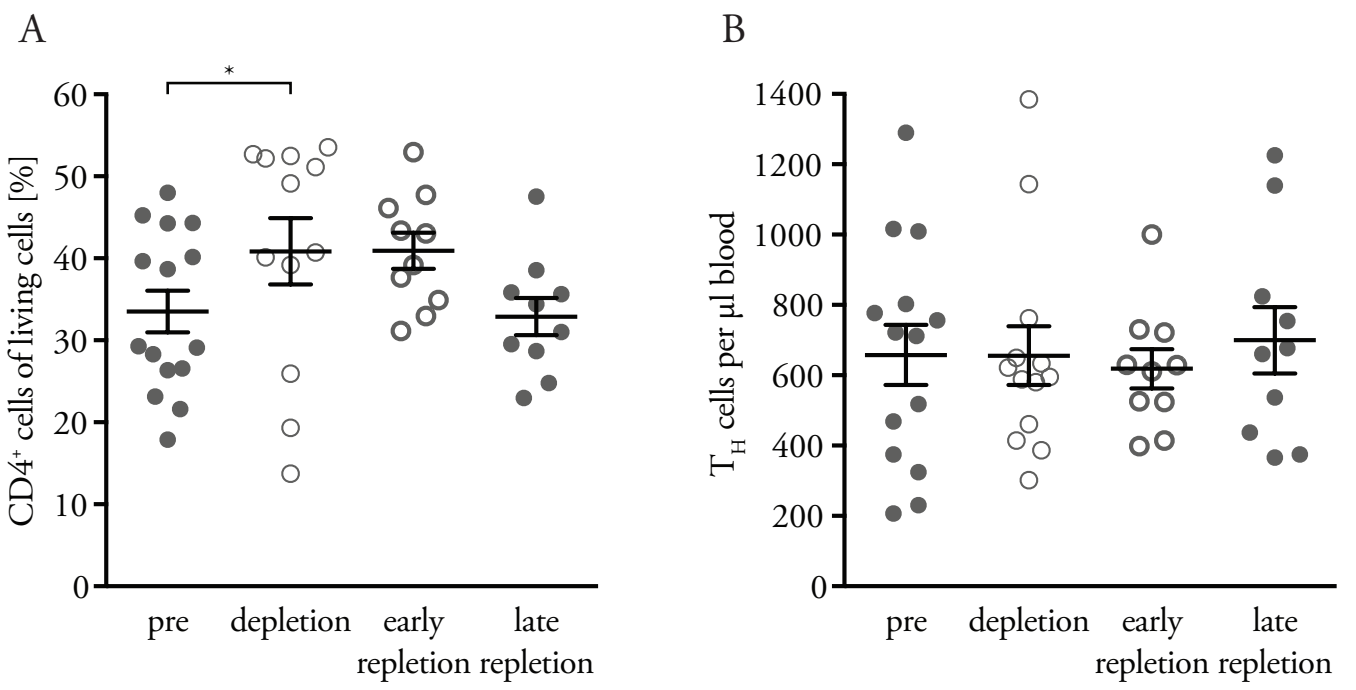

Figure 15. $\mathrm{CD} 4{ }^{+} \mathrm{T}_{\mathrm{H}}$ cells frequency and cell count. The figure shows the frequencies of $\mathrm{CD} 4^{+}$cells expressed as $\%$ of all living PBMCs unstimulated (A) and the $\mathrm{T}_{\mathrm{H}}$ cell counts determined in a TBNK classification of whole blood (B) in four time points for every patient. Data is presented as mean \pm standard error of mean $(n=15 / 12 / 10 / 10$; Wilcoxon matched-pairs signed rank test: $n s$ unless otherwise stated).

As mentioned above, the $\mathrm{CD}^{+} \mathrm{T}_{\mathrm{H}}$ cells maturation phenotype through the four time points was of great interest, for changes could affect the disease progression. The CD $4^{+} \mathrm{T}_{\mathrm{H}}$ cells maturation phenotype as presented in Figure 16 shows a majority of $\mathrm{T}_{\mathrm{TD}}(47.2 \%)$ followed by $\mathrm{T}_{\mathrm{EM}}(13.4 \%), \mathrm{T}_{\mathrm{CM}}(11.9 \%)$ and $\mathrm{T}_{\mathrm{N}}(11.8 \%)$. A significant increase in $\mathrm{T}_{\mathrm{N}}, \mathrm{T}_{\mathrm{CM}}$, and $\mathrm{T}_{\mathrm{EM}}$ frequencies between pre-treatment and late depletion can be seen to $18.4 \%$, corresponding $18.6 \%$ and a corresponding significant decrease in $\mathrm{T}_{\mathrm{TD}}$ from $47.2 \%$ to $34.4 \%$, which doesn't change the order, but reducing the difference between the populations' frequencies. Moreover, $\mathrm{T}_{\mathrm{CM}}$ and $\mathrm{T}_{\mathrm{EM}}$ frequencies show a characteristic trend: slightly increasing at depletion, decreasing at early repletion and again increasing at late repletion. 
A

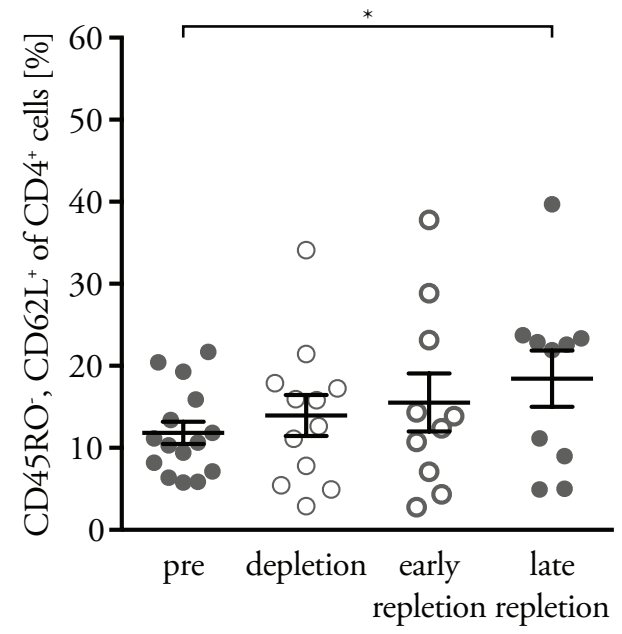

C

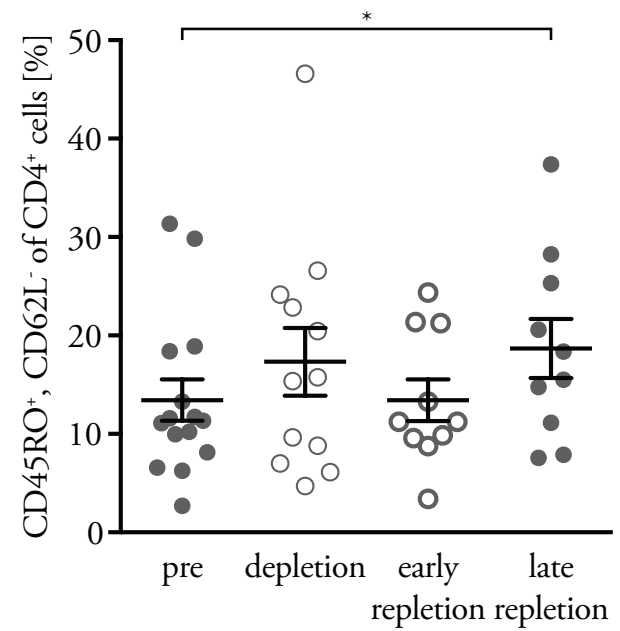

$\mathrm{B}$

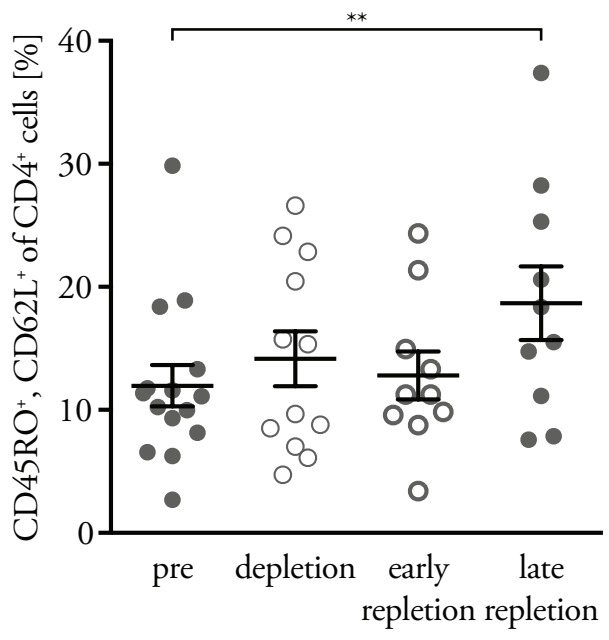

$\mathrm{D}$

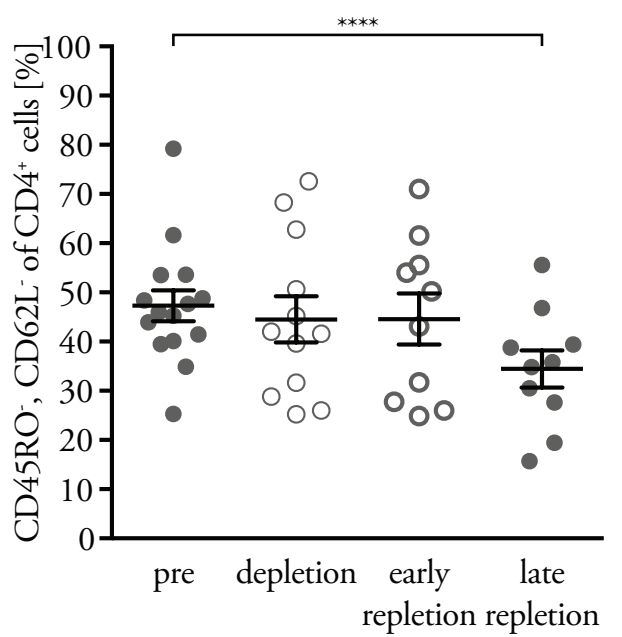

Figure 16. $\mathrm{CD} 4^{+} \mathrm{T}_{\mathrm{H}}$ cells maturation phenotype. The figure shows the frequencies of naïve (A), central memory (B), effector memory (C) and terminally differentiated (D) $\mathrm{T}_{\mathrm{H}}$ cells expressed as $\%$ of $\mathrm{CD}^{+}$cells through four time points for every patient. Data is presented as mean \pm standard error of mean ( $n=15 / 12 / 10 / 10$; paired $t$-test/Wilcoxon matched-pairs signed rank test: $n s$ unless otherwise stated).

As CD62L is a surface antigen used to migrate though the blood vessels in the periphery, its overall expression was of interest. Figure 17 shows the increasing overall CD62L expression by $\mathrm{CD}^{+} \mathrm{T}_{\mathrm{H}}$ cells through all time points, showing a significance only between the time points before therapy and the transition between early and late repletion. This corresponds to the trends shown in Figure 16, an increase in $\mathrm{T}_{\mathrm{N}}$ and $\mathrm{T}_{\mathrm{CM}}$ (expressing CD62L) and a decrease in $\mathrm{T}_{\mathrm{TD}}$. 


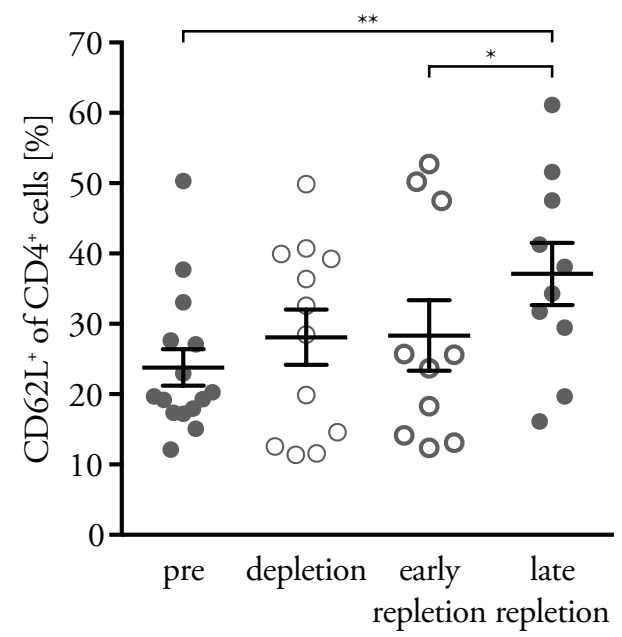

Figure 17. CD4 ${ }^{+} \mathrm{T}_{\mathrm{H}}$ cells' CD62L expression. The figure shows the frequencies of CD62L $\mathrm{L}^{+} \mathrm{T}_{\mathrm{H}}$ cells expressed as \% of $\mathrm{CD}^{+}$cells through four time points for every patient. Data is presented as mean \pm standard error of mean $(n=15 / 12 / 10 / 10$; Wilcoxon matched-pairs signed rank test: $n s$ unless otherwise stated).

\subsubsection{Effects on $\mathrm{CD}^{+}$cytotoxic $\mathrm{T}_{\mathrm{C}}$ cells}

$\mathrm{CD}^{+} \mathrm{T}_{\mathrm{C}}$ cells are the dominant cell population in MS lesions. Therefore, it was of great interest to examine the influence of anti-CD20 therapy on this immune cell population. Figure 18 shows, that the $\mathrm{CD} 8^{+} \mathrm{T}_{\mathrm{C}}$ cells' frequencies and cell counts in the four time points for every patient hardly change. A slight non-significant decrease in cell count can be seen upon CD20 depletion, which could be contributed to the fact, that $16.3 \%$ of $\mathrm{CD}^{+} \mathrm{T}_{\mathrm{C}}$ cells are $\mathrm{CD} 20^{+}$as shown in Figure 10.

A

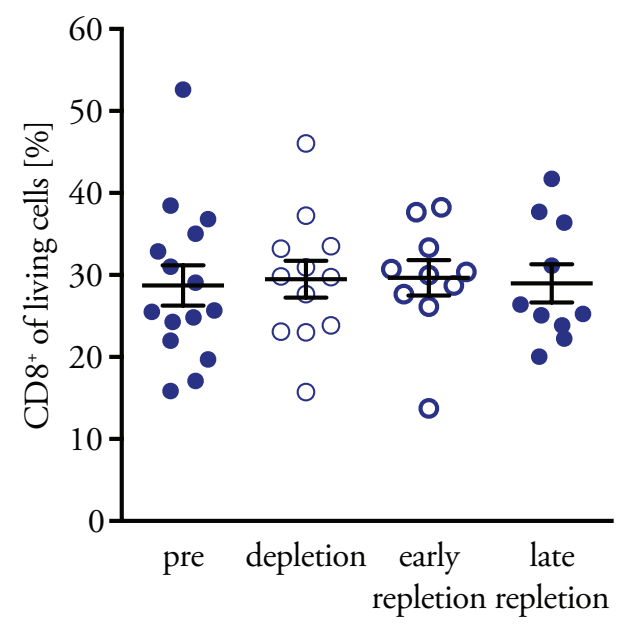

$\mathrm{B}$

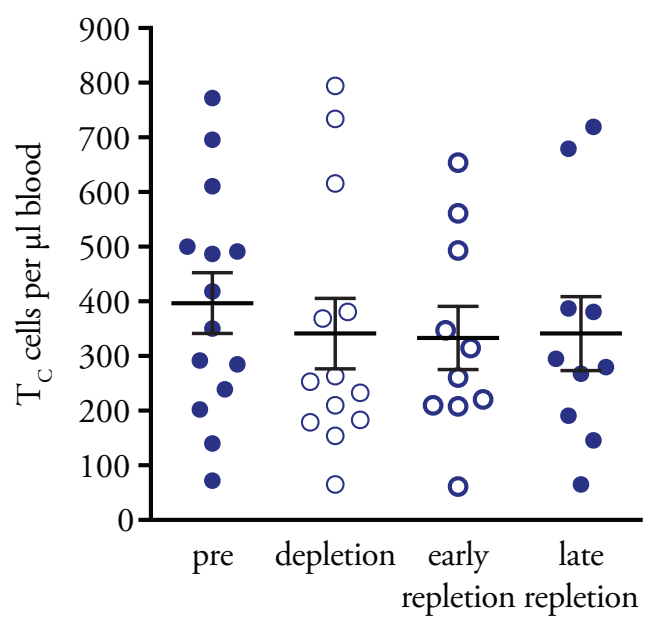

Figure 18. $\mathrm{CD} 8^{+} \mathrm{T}_{\mathrm{C}}$ cells frequency and count. The figure shows the frequencies of $\mathrm{CD} 8^{+}$cells expressed as \% of all living PBMCs unstimulated (A) and the $\mathrm{T}_{\mathrm{C}}$ cell counts determined in a TBNK classification of whole blood (B) in four time points for every patient. Data is presented as mean \pm standard error of mean $(n=15 / 12 / 10 / 10$; Wilcoxon matched-pairs signed rank test: $n s$ unless otherwise stated). 
As previously mentioned, the $\mathrm{CD}^{+} \mathrm{T}_{\mathrm{C}}$ cells maturation phenotype through the four time points was of great interest, for changes could affect the disease progression. The $\mathrm{CD} 8^{+} \mathrm{T}_{\mathrm{C}}$ cells maturation phenotype, as presented in Figure 19, shows a majority of $\mathrm{T}_{\mathrm{TD}}(53.7 \%)$ followed by $\mathrm{T}_{\mathrm{EM}}(25.9 \%), \mathrm{T}_{\mathrm{N}}(12.4 \%)$ and $\mathrm{T}_{\mathrm{CM}}(7.95 \%)$ before depletion, corresponding to the $\mathrm{CD}^{+} \mathrm{T}_{\mathrm{H}}$ cells. A small, yet significant, increase in $\mathrm{T}_{\mathrm{N}}(16.7 \%)$ and $\mathrm{T}_{\mathrm{CM}}(10.1 \%)$ in comparison to a corresponding decrease in $\mathrm{T}_{\mathrm{TD}}(49.14 \%)$ and $\mathrm{T}_{\mathrm{EM}}(23.8 \%)$ can be seen at late repletion. In addition, a trend corresponding to the frequency changes in $\mathrm{CD} 4{ }^{+} \mathrm{T}_{\mathrm{CM}}$ and $\mathrm{T}_{\mathrm{EM}}$ can be seen: increased frequencies of $\mathrm{T}_{\mathrm{N}}$ and $\mathrm{T}_{\mathrm{CM}}$ at depletion, decreased frequencies at early repletion $\left(\mathrm{CD} 20^{+} \mathrm{T}\right.$ cells repletion) and increased frequencies at late repletion. $\mathrm{T}_{\mathrm{EM}}$ and $\mathrm{T}_{\mathrm{TD}}$ do the opposite, $\mathrm{T}_{\mathrm{TD}}$ significant, $\mathrm{T}_{\mathrm{EM}}$ non-significant

A

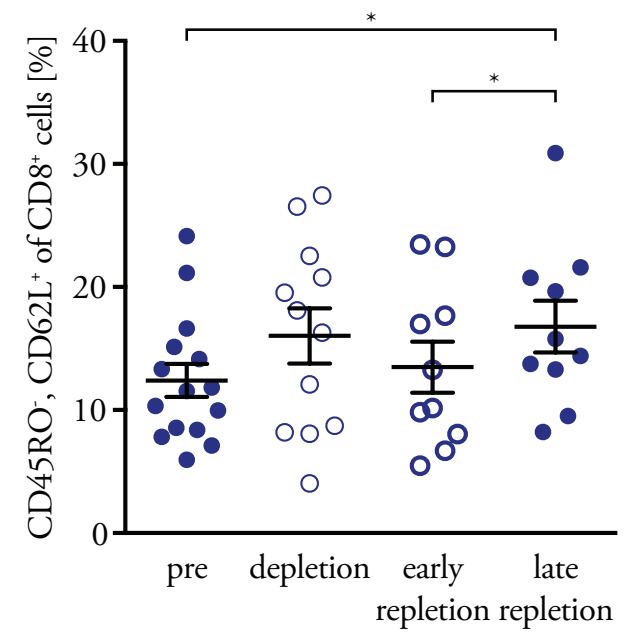

$\mathrm{C}$

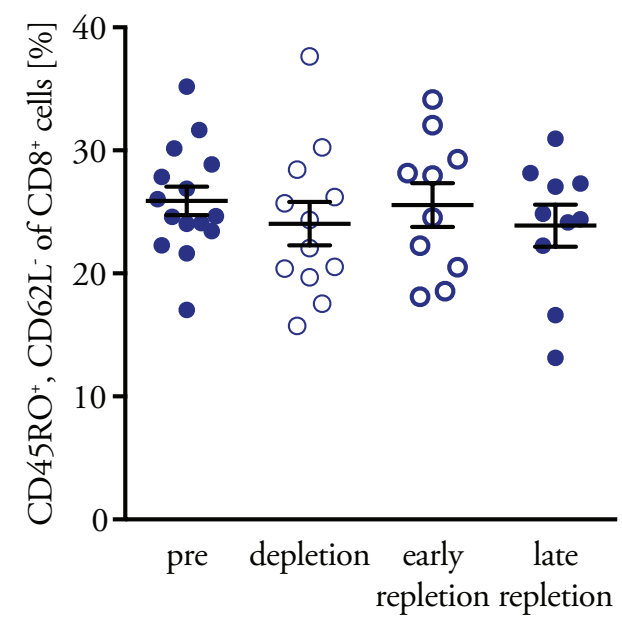

$\mathrm{B}$

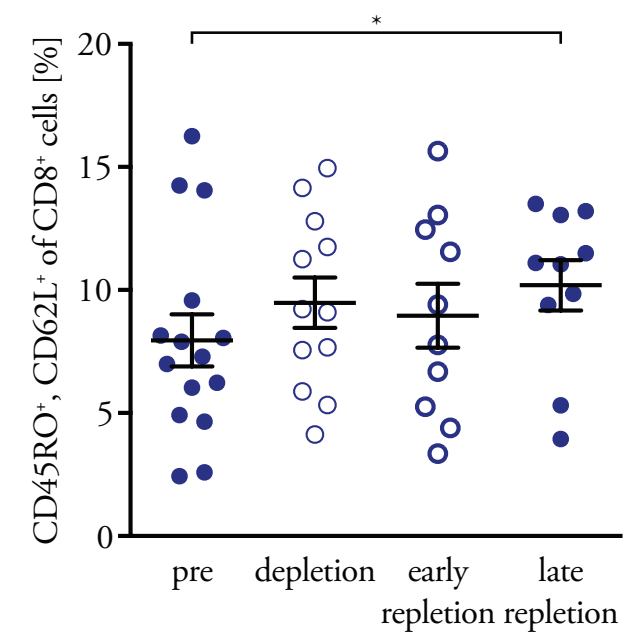

$\mathrm{D}$

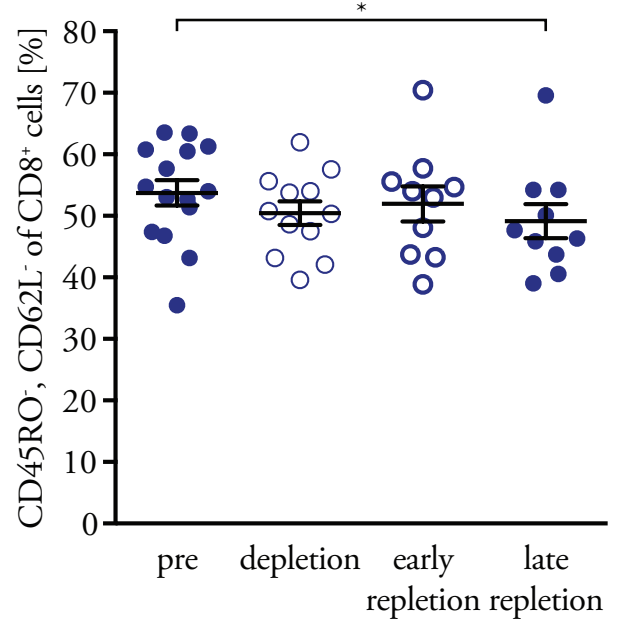

Figure 19. $\mathrm{CD}^{+} \mathrm{T}_{\mathrm{C}}$ cells maturation phenotype. The figure shows the frequencies of naïve (A), central memory (B), effector memory (C) and terminally differentiated (D) $T_{C}$ cells expressed as $\%$ of $\mathrm{CD}^{+}{ }^{+}$cells through four time points for every patient. Data is presented as mean \pm standard error of mean ( $n=15 / 12 / 10 / 10$; paired t-test: ns unless otherwise stated).

As CD62L is a surface antigen used to migrate though the blood vessels in the periphery, its overall expression was of interest. Figure 20 shows, that the overall CD62L expression by 
$\mathrm{CD}^{+} \mathrm{T}_{\mathrm{C}}$ cells slightly increases from $20.3 \%$ before depletion to $25.5 \%$ at depletion, decreasing to $22.5 \%$ at early repletion and again increasing to $27 \%$ at late repletion, corresponding to the trend seen in the frequencies of $\mathrm{T}_{\mathrm{N}}, \mathrm{T}_{\mathrm{CM}}$ and $\mathrm{T}_{\mathrm{TD}}$ (Figure 19).

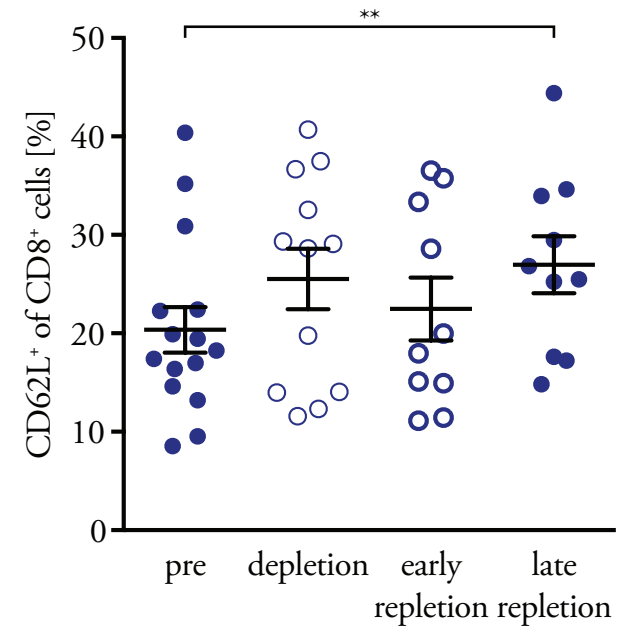

Figure 20. CD8 ${ }^{+} T_{C}$ cells' CD62L expression. The figure shows the frequencies of CD62L ${ }^{+} T_{C}$ cells expressed as \% of $\mathrm{CD}^{+}$cells through four time points for every patient. Data is presented as mean \pm standard error of mean ( $n=15 / 12 / 10 / 10$; Wilcoxon matched-pairs signed rank test: $n s$ unless otherwise stated). 


\subsubsection{Effects on myeloid cells}

The interaction between myeloid APCs and T cells is of great interest, since myeloid cells could, on the one hand, stimulate the $\mathrm{T}$ cells through antigen presentation or through pro-inflammatory cytokine secretion, but on the other hand, reduce the immune reaction through anti-inflammatory cytokines. As Figure 21 shows, the CD14 $4^{+}$myeloid cells' frequencies increase relatively through the four time points, even though the monocytes' cell counts in the four time points don't change.
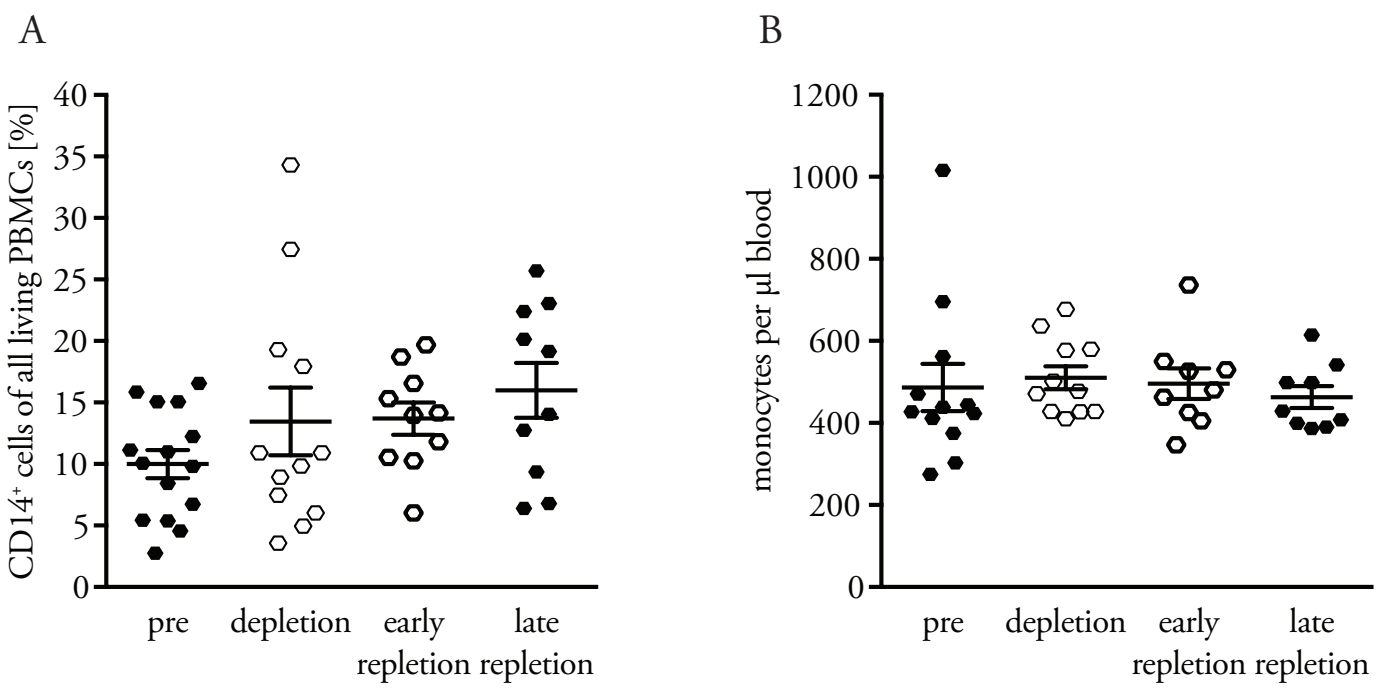

Figure 21. $\mathrm{CD}_{14}{ }^{+}$myeloid cells frequency and monocytes' cell count. The figure shows the frequencies of $\mathrm{CD} 14^{+}$cells expressed as \% of all living PBMCs unstimulated (A) and the monocytes' cell counts calculated from hemogram (B) in four time points for every patient. Data is presented as mean \pm standard error of mean $(n=15 / 12 / 10 / 10$; Wilcoxon matched-pairs signed rank test: $n s$ unless otherwise stated).

In the myeloid cells' activation panel, the expressions of CD95 (FAS) and CD150, were analyzed. Figure 22 shows, that the myeloid cells' low CD150 expression, which varied before depletion, becomes unanimous at depletion. It then decreases at early repletion and varies again at late repletion, all non-significant. The overall expression of CD150 hardly changes. The figure also shows the myeloid cells' ubiquitous expression of CD95 (FAS), and the changes in its MFI. The CD95 (FAS) expression stays at three of the time points constant, yet increases significantly at early repletion, when compared to the expression before therapy. 
A

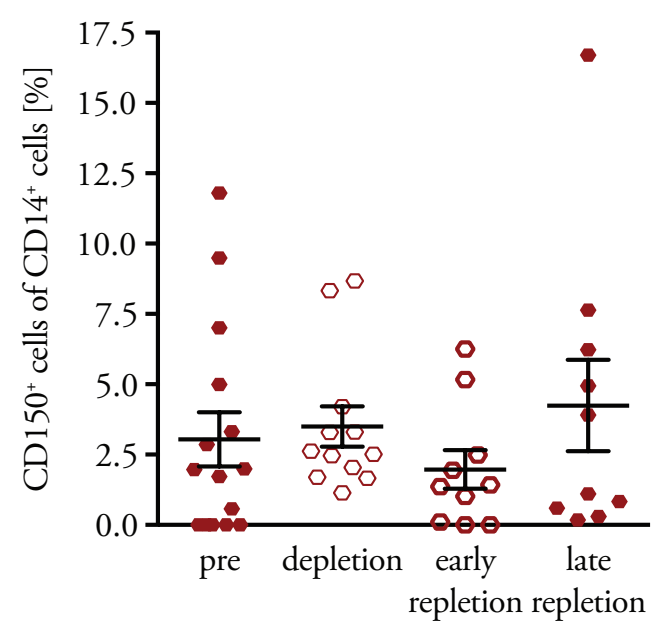

$\mathrm{B}$

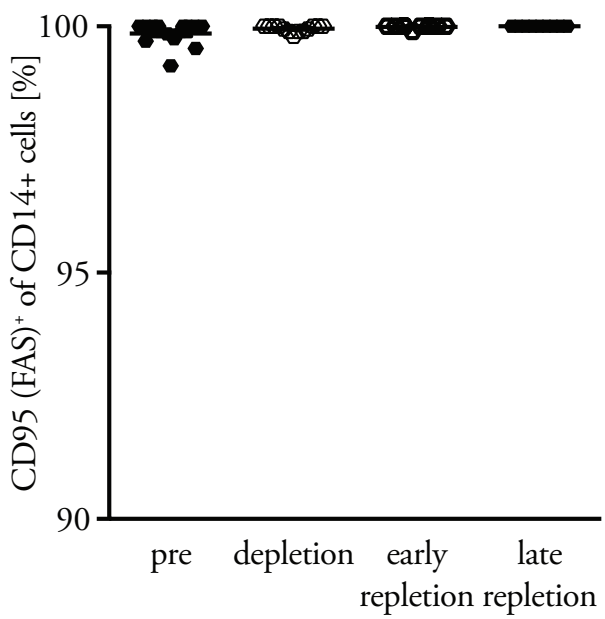

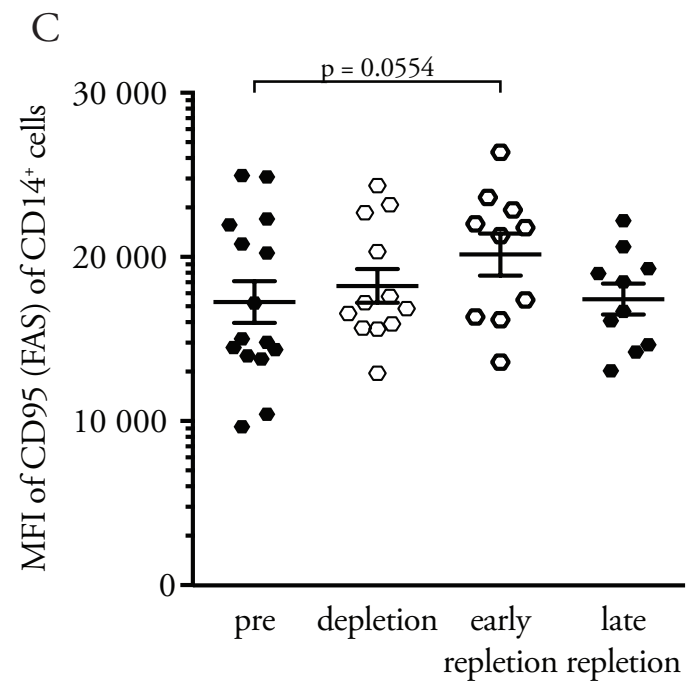

Figure 22. Myeloid cells' activation phenotype. The figure shows the (A) frequencies of CD150+ myeloid cells expressed as \% of $\mathrm{CD}_{14}{ }^{+}$cells upon LPS stimulation $[100 \mathrm{pg} / \mathrm{ml}$, as shown in Table 11, (B) the frequencies of CD95 (FAS)+ myeloid cells expressed as \% of CD14+ cells and (C) MFI of CD95 (FAS) of CD14+ cells through four time points for every patient. Data is presented as mean \pm standard error of mean $(n=15 / 12 / 10 / 10$; Wilcoxon matched-pairs signed rank test/paired t-test: ns unless otherwise stated).

Like B cells, myeloid cells are professional APCs, and as such, they could interact with T cells. With the potential to take over the B cells' function as APCs, the myeloid cells' APC phenotype was of great interest. Figures 23 and 24 show the myeloid cells' APC phenotype. The myeloid cells' CD40 expression slightly increases, reaching a maximum at late repletion, but at $\mathrm{B}$ cell repletion decreases to its original level, all non-significant. The same trend can be seen in the MFIs of this surface antigen, showing a significantly increased expression at early repletion compared with the expression before therapy. At late repletion the expression decreases to its original level. The MHC-II expression acts the same, increasing at depletion and at early repletion and sinking, this time below its original level at late repletion. One could see through the MHC-II expression, that the myeloid cells' reaction 
to the anti-CD20 depletion differs from patient to patient. Though the mean of said surface antigen only slightly changes, the variability changes at early repletion.

The myeloid cells' CD80 expression almost doesn't change throughout the different time points, and their CD86 expression shows a similar trend to the $\mathrm{T}_{\mathrm{C}}$ and $\mathrm{T}_{\mathrm{H}}$ cells, increasing at depletion, slightly decreasing at early repletion and again increasing at late repletion.

A

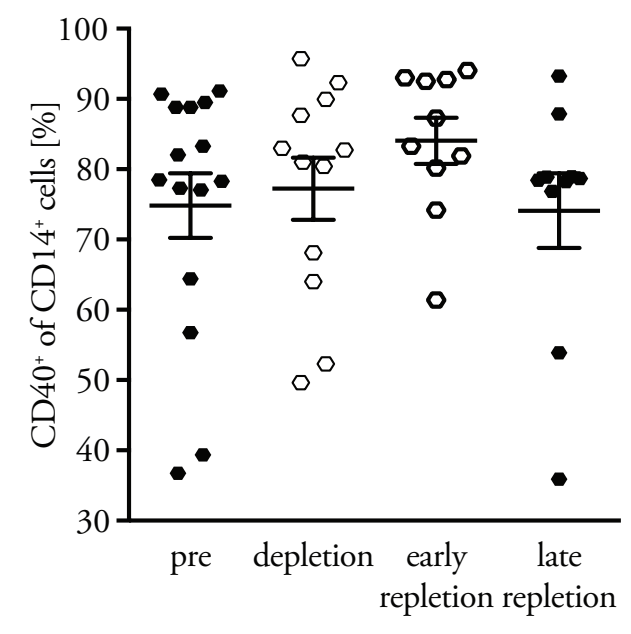

C

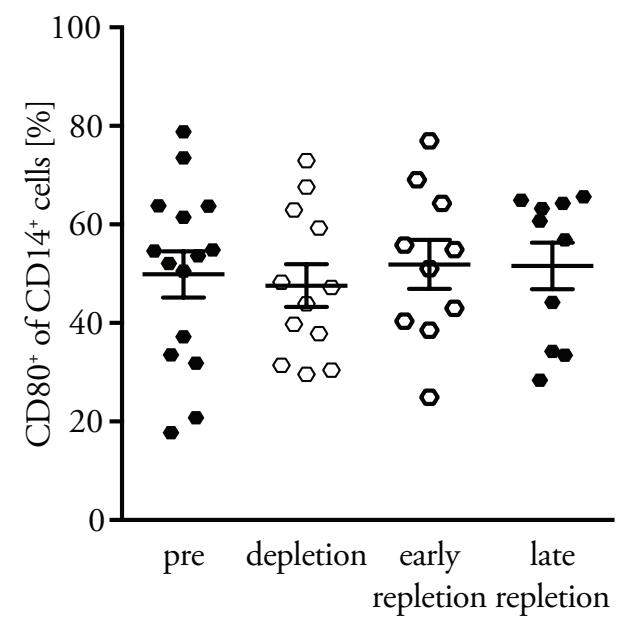

B

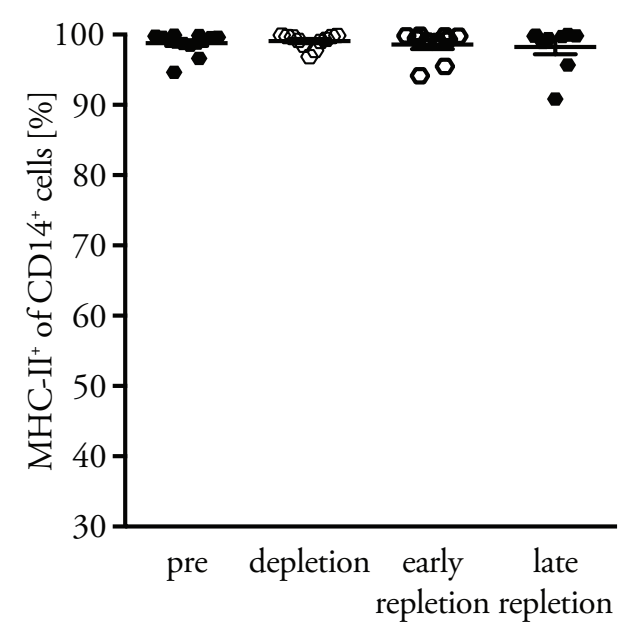

$\mathrm{D}$

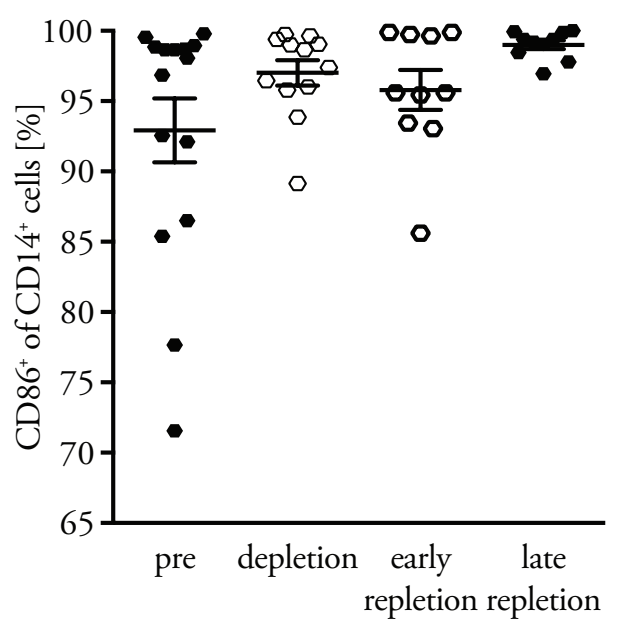

Figure 23. Myeloid cells' APC phenotype I. The figure shows the frequencies of $\mathrm{CD}^{4} 0^{+}(\mathrm{A})$,

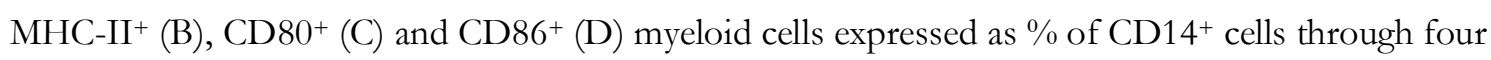
time points for every patient. Data is presented as mean \pm standard error of mean $(n=15 / 12 / 10 / 10$; paired t-test/Wilcoxon matched-pairs signed rank test: ns unless otherwise stated). 

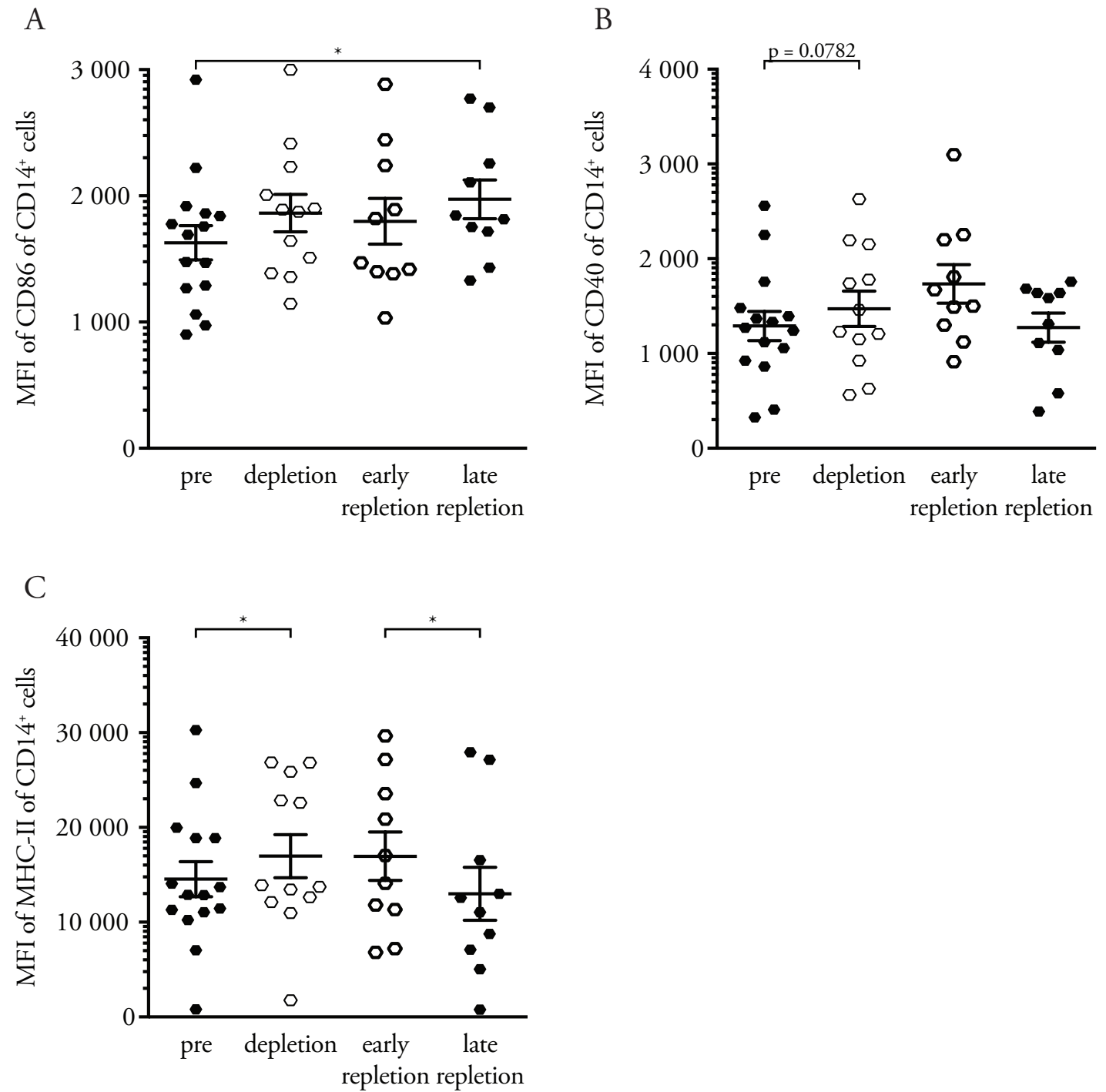

Figure 24. Myeloid cells' APC phenotype II. The figure shows the MFIs of CD86 (A), CD40 (B) and MHC-II (C) of $\mathrm{CD}_{14}{ }^{+}$cells through four time points for every patient. Data is presented as mean \pm standard error of mean $(n=15 / 12 / 10 / 10$; paired $t$-test/Wilcoxon matched-pairs signed rank test: ns unless otherwise stated).

The myeloid cells' cytokine secretion phenotype as a possible immune modulating factor was of great interest in the project. As shown in Figure 25, all myeloid cells produce IL-6, independent of the stimulation. Nevertheless, one could see in the MFIs, that unstimulated some myeloid cells produce more IL-6 at early repletion, and maintain that level at late repletion. The non-significant differences in the MFIs show again the difference in the variability of the myeloid cells at early repletion, which persists at late repletion as well. One could say, that overall the myeloid cells don't necessarily produce more IL-6 (no change in mean), but the range of their values increases, indicating that the single cells within the group vary. Upon CpG stimulation the myeloid cells' IL-6 production increases already at depletion, continues to increase at early repletion, and slightly sinks at late repletion. The difference in the variability can be seen here as well. This doesn't apply to the 
LPS stimulation, where the myeloid cells' IL-6 production remains constant, and the variability doesn't change either.

Figure 26 shows the myeloid cells' IL-10 and TNF- $\alpha$ production. The IL-10 production remains mainly constant, but shows upon LPS stimulation a different trend than unstimulated and upon CpG stimulation. Unstimulated and upon CpG stimulation the IL-10 production slightly increases at depletion, again at early repletion and sinks blow its original value at late repletion. Upon LPS stimulation the IL-10 production first significantly sinks at depletion, then, besides two patients, remains constant at early repletion, and increases at late repletion, but stays below original value.

The myeloid cells produce TNF- $\alpha$ upon $\mathrm{CpG}$ stimulation, unstimulated and upon LPS stimulation increasingly. Unstimulated myeloid cells' TNF- $\alpha$ production increases minimally at depletion, remains at that level at early repletion, and sinks at late repletion below original level. Upon CPG stimulation it increases again minimally at depletion, but sinks already at early repletion, and remains at that level at late repletion. Upon LPS stimulation it increases through depletion until early repletion, then sinks at late repletion slightly below original level. As shown in Figures 25 and 26 most changes are non-significant.

A

A

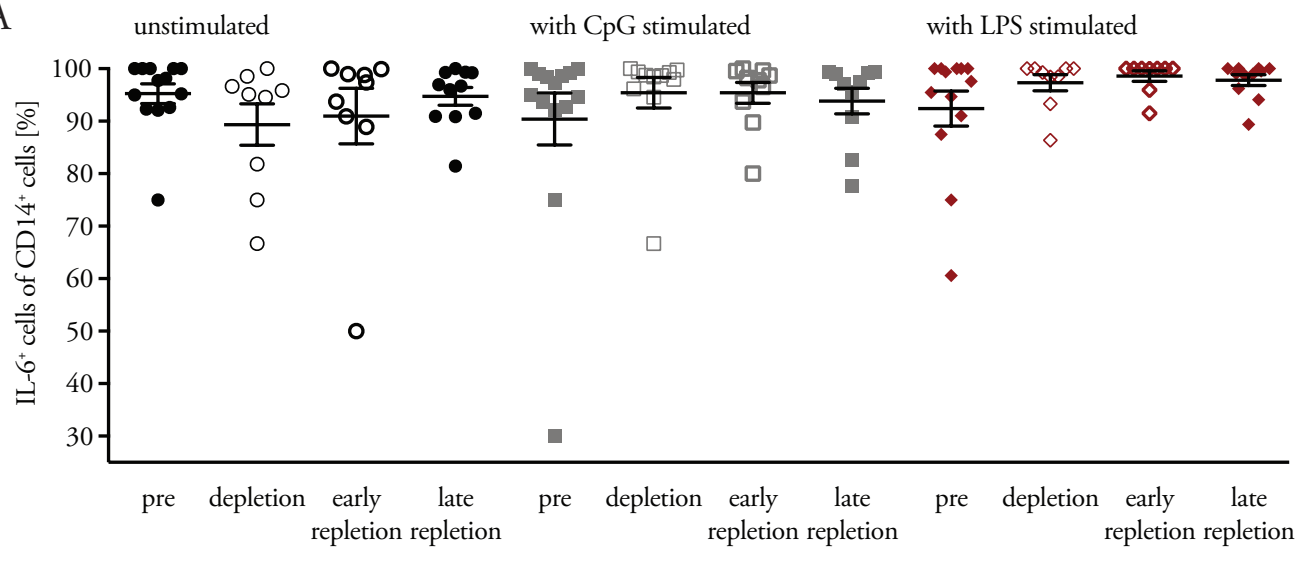

B

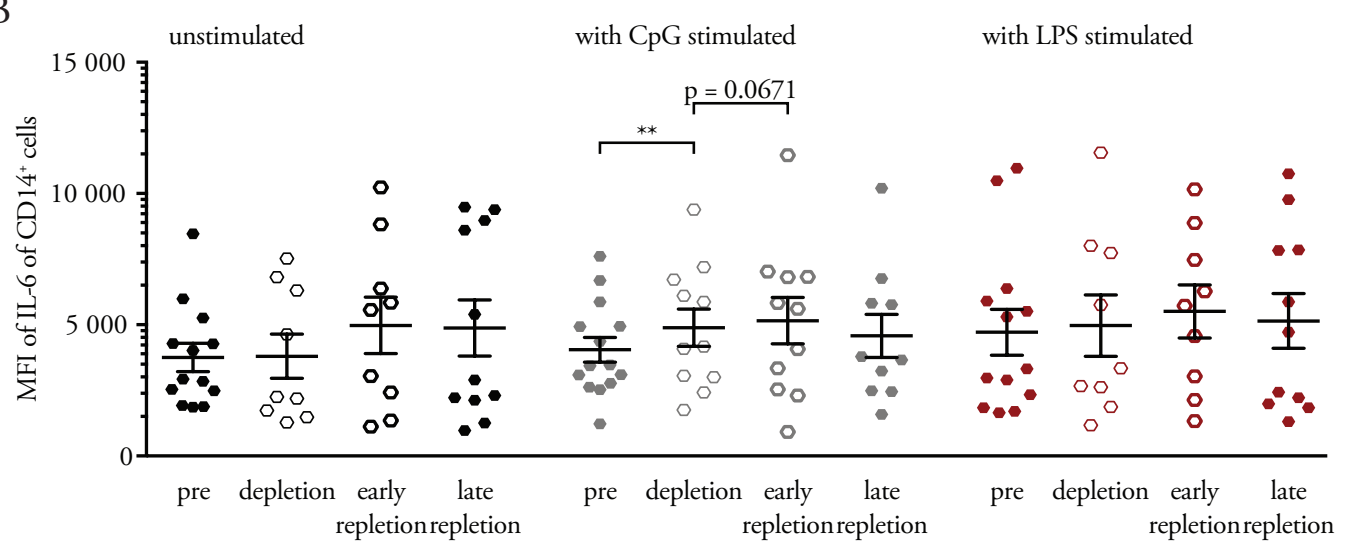

Figure 25. Myeloid cells' IL-6 phenotype. The figure shows the frequencies of IL- $6^{+}$myeloid cells expressed as $\%$ of $\mathrm{CD}_{14}{ }^{+}$cells (A), and MFI of $\mathrm{IL}-6$ of $\mathrm{CD} 14^{+}$cells (B) unstimulated and upon CpG $[1 \mu \mathrm{g} / \mathrm{ml}]$ and LPS [500 $\mathrm{pg} / \mathrm{ml}]$ stimulation, as shown in Table 11, through four selected samples 
representing four selected time points for every patient. Data is presented as mean \pm standard error of mean ( $n=15 / 9,11,9 / 9,10,9 / 10,11$; paired t-test/Wilcoxon matched-pairs signed rank test: $n s$ unless otherwise stated).

A
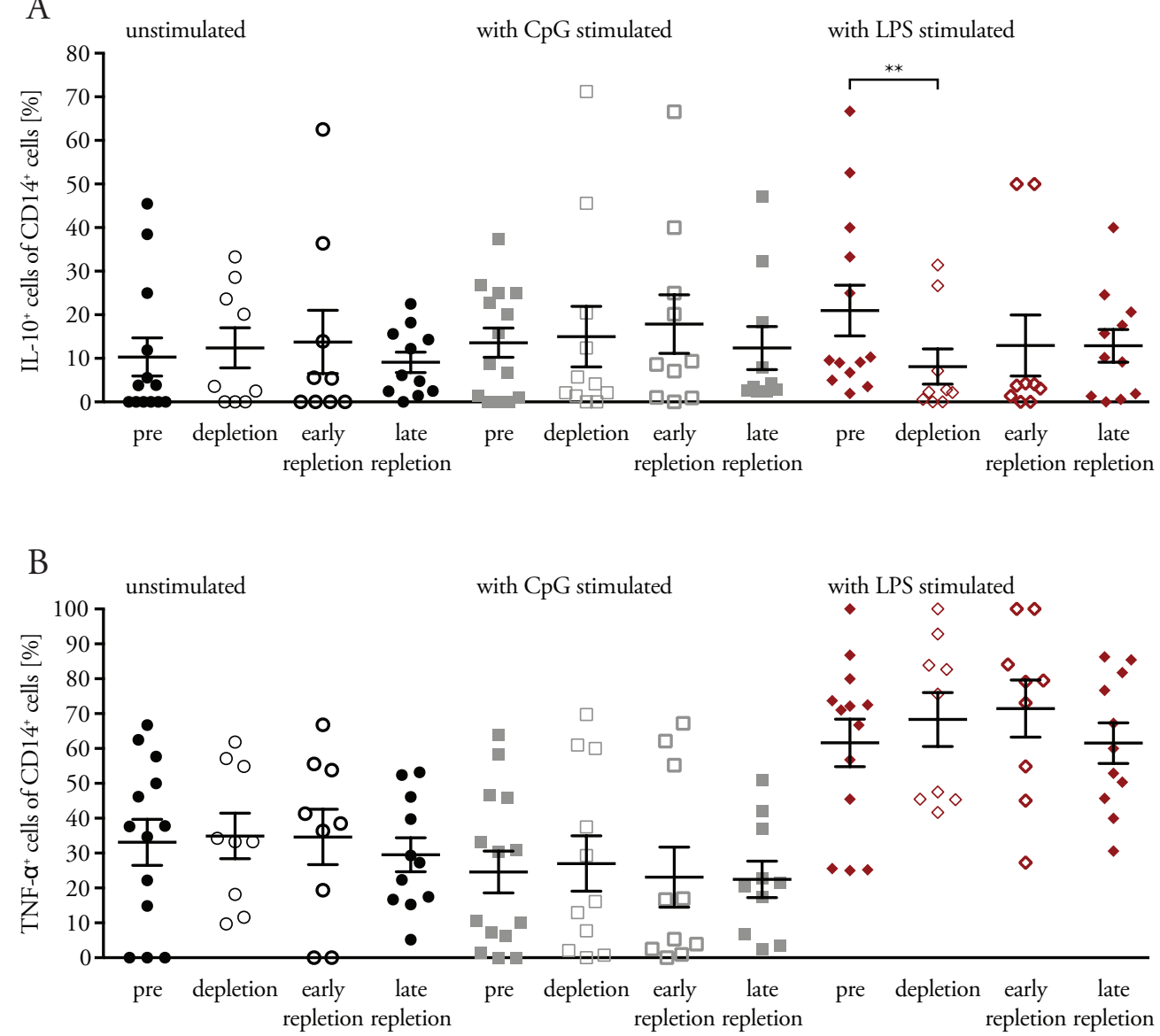

Figure 26. Myeloid cells' IL-10 and TNF- $\alpha$ phenotype. The figure shows the frequencies of $\mathrm{IL}-10^{+}$(A) and TNF- $\alpha^{+}$(B) myeloid cells expressed as \% of CD14+ cells unstimulated and upon CpG $[1 \mu \mathrm{g} / \mathrm{ml}]$ and LPS [500 pg/ml] stimulation, as shown in Table 11, through four selected samples representing four selected time points for every patient. Data is presented as mean \pm standard error of mean $(n=15 / 9,11,9 / 9,10,9 / 10,11$; paired t-test/Wilcoxon matched-pairs signed rank test: ns unless otherwise stated). 


\subsection{Correlation with clinical parameters}

Anti-CD20 therapy shows significant clinical effects in MS therapy. This raises the question of the role of $\mathrm{B}$ cells in the pathogenesis. MS is also more common by women than men, and manifests usually between 25 and 35 years of age. As such, the correlations between patient's age, sex and B cell frequency, respectively count, were of great interest, and are shown in Figure 27. The figure shows, that with increasing age, the B cell frequency and the $\mathrm{B}$ cell counts increase significantly. When separating male and female patients, one can still see a significantly positive correlation only among the female patients.

It is important to mention, that I have only looked at 15 patients. Therefore, the results should be interpreted very carefully.

A

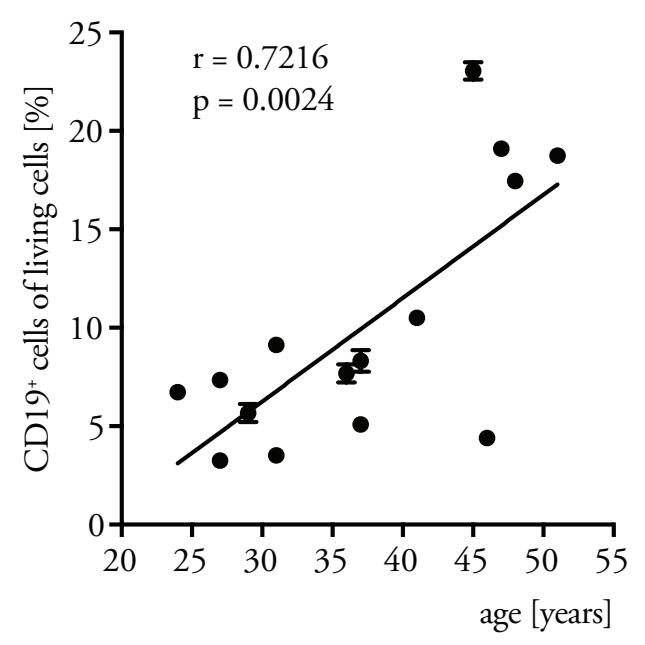

$\mathrm{B}$

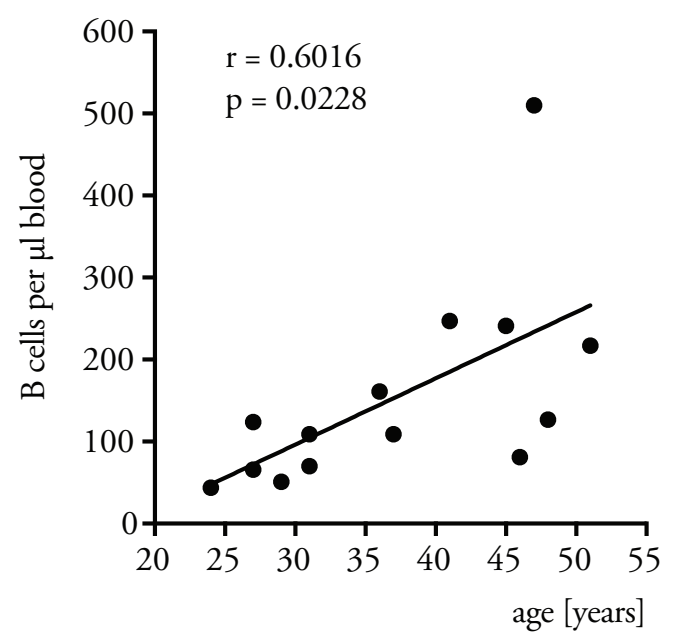

$\mathrm{D}$
C

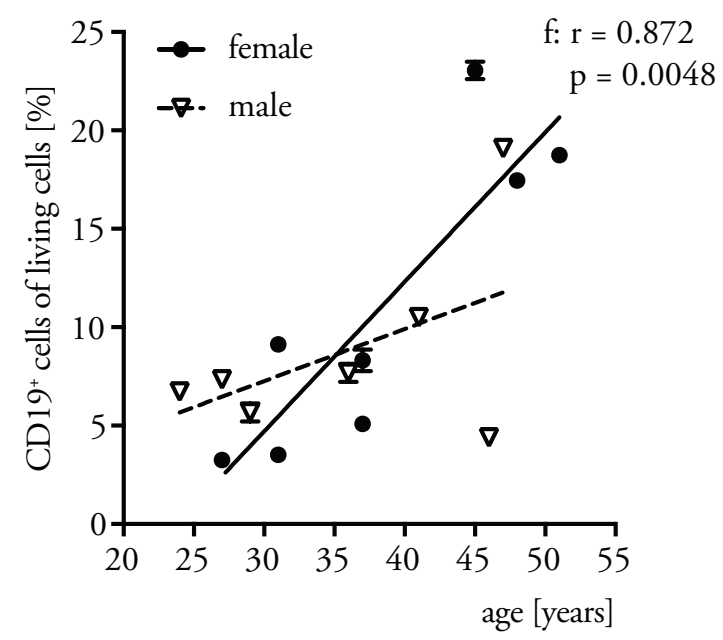

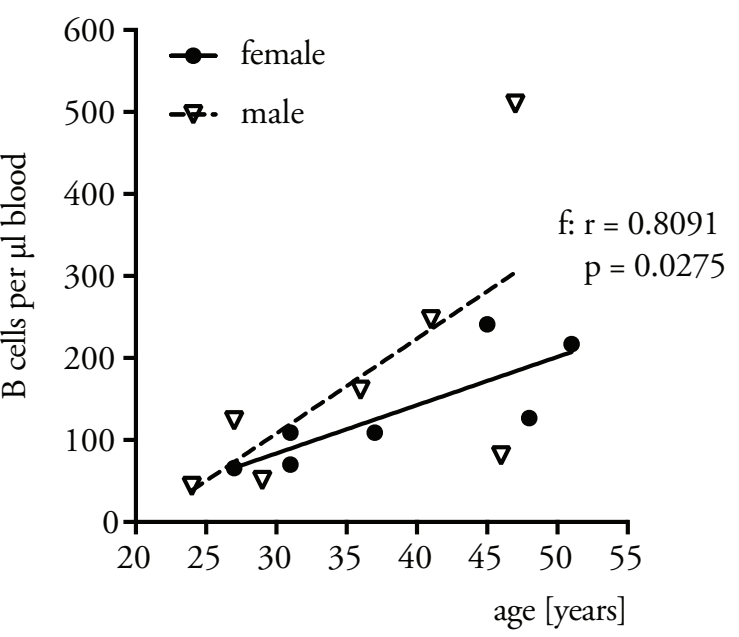

Figure 27. Correlation between $B$ cell frequency/count with age and sex. The figure shows the frequency of $\mathrm{CD} 19^{+}$cells expressed as \% of all living PBMCs (A, C) and B cell counts determined in a TBNK classification of whole blood (B, D), both before depletion, and patients' age. Data is presented as mean \pm standard error of mean $(\mathrm{n}=15, \mathrm{f}=8, \mathrm{~m}=7(\mathrm{~A}, \mathrm{C}) / \mathrm{n}=14, \mathrm{f}=7, \mathrm{~m}=7$ $(\mathrm{B}, \mathrm{D})$, linear regression, Pearson $\mathrm{r} ; \mathrm{C}-\mathrm{m}: \mathrm{p}=0.2531, \mathrm{D}-\mathrm{m}: \mathrm{p}=0.1102$, both not shown in figure). 
In light of these findings and the efficacy of anti-CD20 therapy, the correlation between the patients' clinical EDSS score and the B cell frequency and count was also analyzed. A significant positive correlation between B cell frequency respectively B cell count and the patients' EDSS score was found, which could be explained due to the correlation with age $(\mathrm{r}=0,5468, \mathrm{p}=0,0368$; data not shown).

Naïve and memory B cells are the largest B cell populations circulating in peripheral blood (as shown in Figure 5), yet these population differ in their characteristics. Naïve B cells aren't antigen experienced, memory B cells are. Naïve B cells tend to have a more anti-inflammatory profile, whereas memory B cells a more pro-inflammatory one. Therefore, the correlations between the frequencies of these populations and the EDSS score of the patients were of interest, and are shown in Figure 28. One can see, that a strong correlation between all but one patient (in grey) was found with both frequencies. Figure 28 shows, that the EDSS score of all patients positively correlates with the naive B cell frequency. The memory B cell frequency and EDSS score, on the other hand, correlates negatively (in all but the one patient in grey). The ratio naive/memory B cells shows a positive correlation between in all patients (data not shown, $\mathrm{r}=0.841, \mathrm{p}=0.0003$; when $\mathrm{n}=15 \mathrm{r} \mathrm{r}=0.539, \mathrm{p}=0.0403$ ). A correlation of those three parameters with age was also analyzed to exclude a secondary correlation, and was not found (see Figure A1).

A

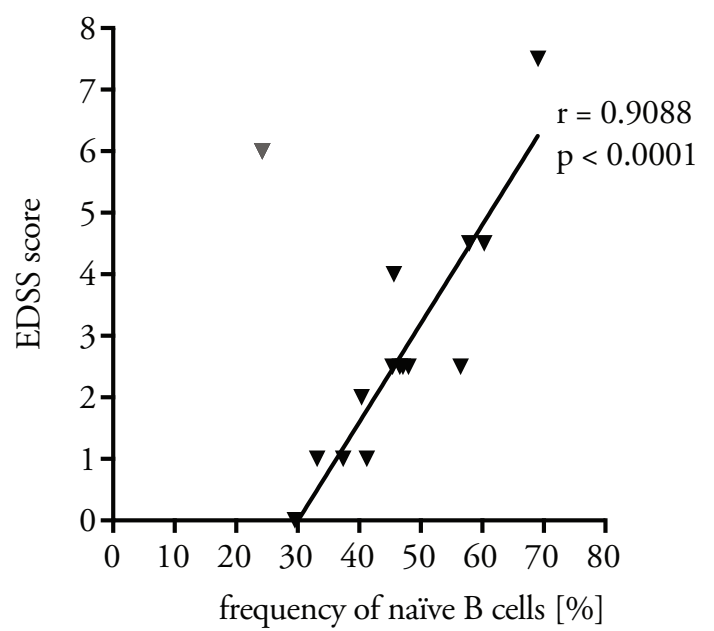

B

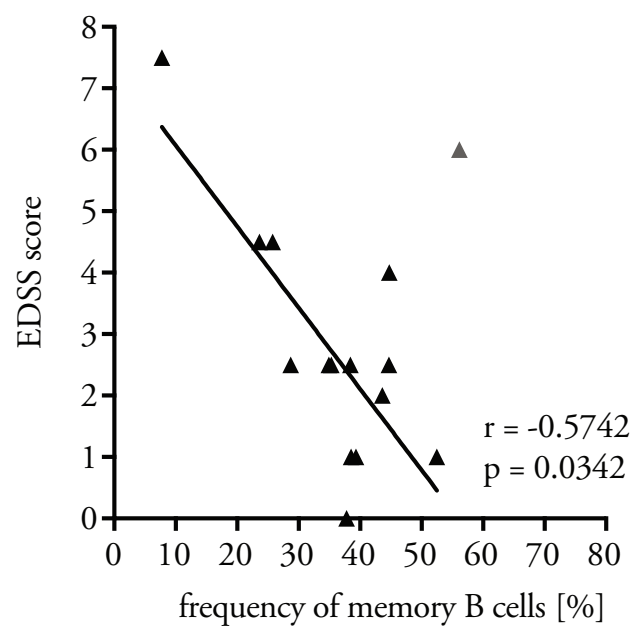

Figure 28. Correlation between naïve and memory B cell frequencies with EDSS score. The figure shows the frequency of naive (A) and memory (B) B cells expressed as $\%$ of CD19+ cells, both before depletion and patients' EDSS score at time of first administration of anti-CD20 therapy ( $\mathrm{n}=14$, linear regression, Spearman $\mathrm{r}$; when $\mathrm{n}=15: \mathrm{A}: \mathrm{p}=0.0216\left(^{*}\right), \mathrm{r}=0.5938 ; \mathrm{B}: \mathrm{p}=0.2385, \mathrm{r}=-0.3234$ all not shown in figure).

In light of these findings it was interesting to determine, if one could identify patients who would more profit from an anti-CD20 therapy, based on the ratio between naïve and memory B cells. On the one hand as stated in 1.1.2.7 above the "good" anti-inflammatory are the naïve B cells and the "bad" pro-inflammatory are the memory B cells. On the other hand, as seen in Figure 28, the more naïve B cells a patient has, the worst the EDSS score is, and vice 
versa with the memory B cells. Figure 29 shows a possible classification of all patients in memory/balanced type $(\mathrm{n} / \mathrm{m}$ ratio $\leq 1$, in balanced type the difference between the frequencies of naïve and memory $\mathrm{B}$ cells must not exceed $5 \%$ ) and in naïve type $(\mathrm{n} / \mathrm{m}$ ratio $>1)$. The patient that differed within the correlation to the EDSS score (Figure 28) is presented in gray.
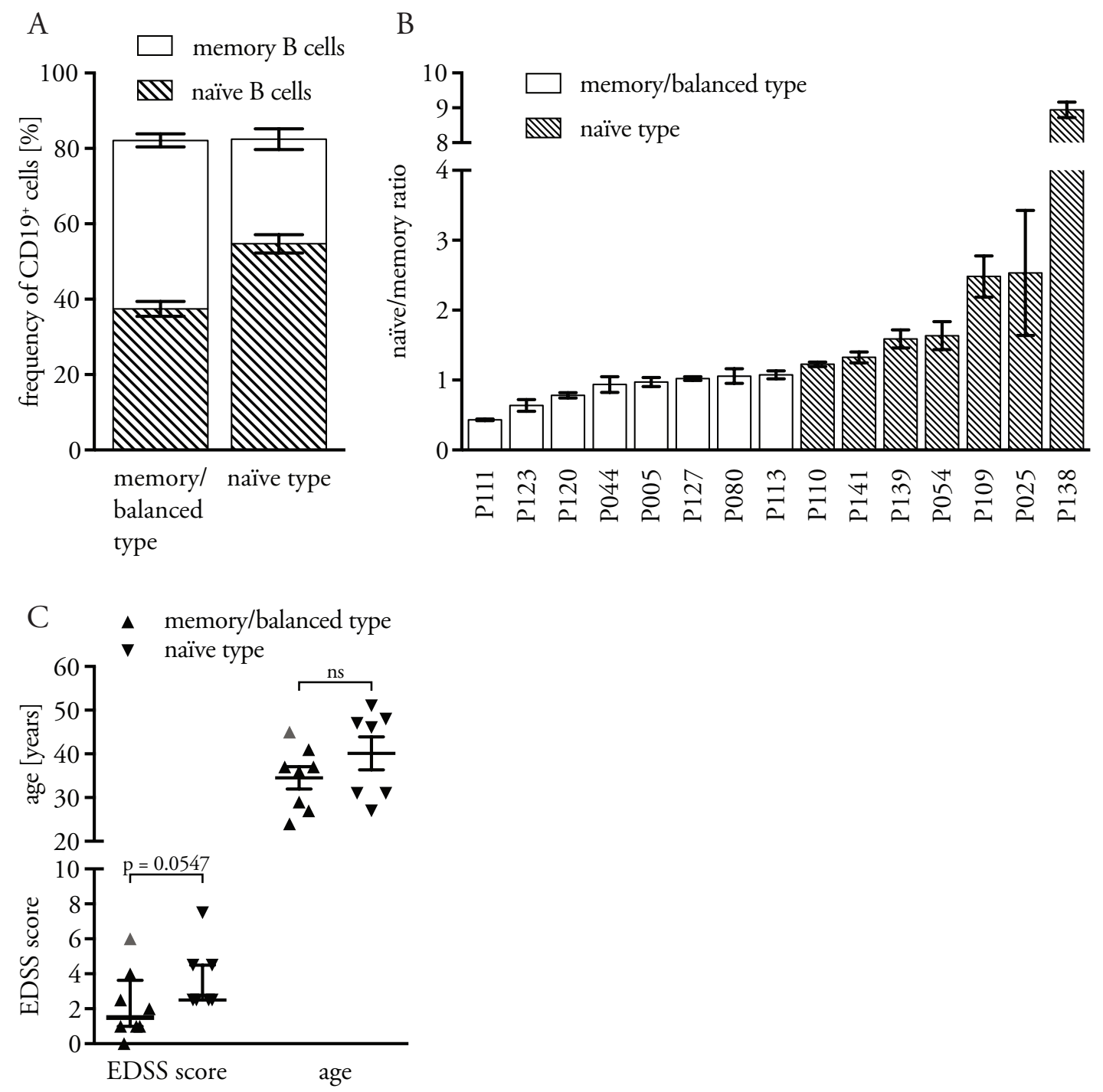

Figure 29. Memory/balanced and naive type. The figure shows (A) the frequency of memory and naïve $\mathrm{B}$ cells expressed as \% of $\mathrm{CD} 19^{+}$cells, both before depletion, (B) the naïve/memory ratio of each patient and $(C)$ the median EDSS score $\pm I Q R /$ range and mean age \pm standard error of mean of the patients in these groups. Data is presented as mean \pm standard error of mean (besides EDSS score; $\mathrm{n}=8 / 7$; unpaired $\mathrm{t}$-test/Mann-Whitney-U-Test as stated in figure)

After defining these two patient groups, I looked at their distribution within the different parameters measured in the study. The median EDSS score ( $\pm \mathrm{IQR} /$ range) of these groups was: memory/balanced type: $1.5 \pm 2.625$, naive type: $2.5 \pm 2.5$. The patients in those groups did not differ in age. Data to those differences is shown in 6.4 below, and is summarized in Table 12. 
Table 12: Differences in immune cell phenotype after anti-CD20 depletion between patients with memory/balanced and naïve B cell phenotype pre-depletion.

\begin{tabular}{|c|c|c|c|}
\hline $\begin{array}{l}\text { Cell } \\
\text { population }\end{array}$ & Surface antigen & $\begin{array}{l}\text { Memory/balance } B \\
\text { cell type }\end{array}$ & Naïve B cells type \\
\hline \multirow[t]{5}{*}{$\mathrm{CD}^{+}{ }^{+} \mathrm{T}_{\mathrm{H}}$ cells } & $\mathrm{T}_{\mathrm{N}}$ & low and increasing & low and constant \\
\hline & $\mathrm{T}_{\mathrm{CM}}$ & low and increasing & low and constant \\
\hline & $\mathrm{T}_{\mathrm{EM}}$ & low and increasing & low and constant \\
\hline & $\mathrm{T}_{\mathrm{TD}}$ & high and decreasing & high and constant \\
\hline & CD62L & high and increasing & high and constant \\
\hline \multirow[t]{5}{*}{$\mathrm{CD}^{+} \mathrm{T}_{\mathrm{C}}$ cells } & $\mathrm{T}_{\mathrm{N}}$ & $\begin{array}{l}\text { low and increasing - } \\
\text { decreasing - } \\
\text { increasing }\end{array}$ & low and constant \\
\hline & $\mathrm{T}_{\mathrm{CM}}$ & $\begin{array}{l}\text { low and increasing - } \\
\text { decreasing - } \\
\text { increasing }\end{array}$ & low and decreasing \\
\hline & $\mathrm{T}_{\mathrm{EM}}$ & $\begin{array}{l}\text { low and decreasing - } \\
\text { increasing - } \\
\text { decreasing }\end{array}$ & low and increasing \\
\hline & $\mathrm{T}_{\mathrm{TD}}$ & high and decreasing & high and increasing \\
\hline & CD62L & low and increasing & high and constant \\
\hline \multirow{9}{*}{$\begin{array}{l}\mathrm{CD}^{+} 4^{+} \\
\text {myeloid cells }\end{array}$} & CD150 & low and constant & low and constant \\
\hline & CD95 (FAS) (MFI) & high and increasing & high and constant \\
\hline & CD40 (MFI) & constant & increasing \\
\hline & CD80 & high and increasing & $\begin{array}{l}\text { very high and } \\
\text { decreasing }\end{array}$ \\
\hline & CD86 (MFI) & high and increasing & high and constant \\
\hline & MHC-II (MFI) & decreasing & increasing \\
\hline & IL-6 (unstimulated) & increasing & decreasing \\
\hline & IL-10 (unstimulated) & low and constant & $\begin{array}{l}\text { low and increasing - } \\
\text { decreasing }\end{array}$ \\
\hline & TNF- $\alpha$ (unstimulated) & low and increasing & low and decreasing \\
\hline EDSS & median $\pm \mathrm{IQR} /$ range & $1.5 \pm 2.625$ & $2.5 \pm 2.5$ \\
\hline
\end{tabular}


All of the above shows that certain changes do occur in the different populations of the immune system after administration of anti-CD20 therapy. Those changes and their opposite happen in some patients, and balance each other in the overall population.

The role of $\mathrm{CD} 20^{+} \mathrm{T}$ cells is still unknown, but their earlier repletion raises the question of origin. One is not entirely sure if those cells come from the bone marrow, suggesting a regulated population with a specific role in the immune system, or if $\mathrm{T}$ cells in the periphery start to re-express CD20. Figure 30 show the correlation between age and the time to detection of repletion. The time to detection of B cell repletion doesn't correlate with age, as a minimum of 250 days can be seen at all times, yet one could notice, that after 40 years of age this time interval prolongs. Nevertheless, the time do detection of $\mathrm{CD} 20^{+} \mathrm{T}$ cell repletion decreases significantly with age.

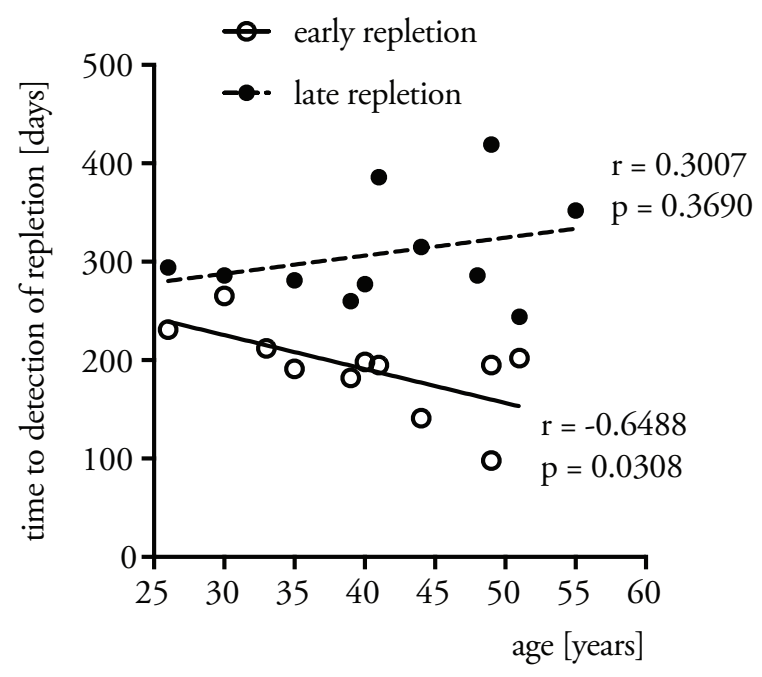

Figure 30. Correlation between the time to detection of $\mathrm{CD} 20^{+}$cells repletion and age. The figure shows the time in days past between last anti-CD20 therapy administration and the detection of $\mathrm{CD} 20^{+} \mathrm{T}$ cells at early repletion and of $\mathrm{CD} 20^{+} \mathrm{B}$ cells at late repletion alongside with patients' age. $(\mathrm{n}=11$, linear regression, Pearson $\mathrm{r})$

In addition, the correlation to patient's age with the frequency of $\mathrm{CD} 20^{+} \mathrm{T}$ cell population was interesting. Figure 31 shows a positive correlation between $\mathrm{CD} 20^{+} \mathrm{T}_{\mathrm{H}}$ cell frequency of all living PBMCs and age. When observing the cell frequencies within the cell populations, one can see, that the frequencies of both cell populations positively correlate with age. When separating male and female, one can see within the $\mathrm{CD} 20^{+} \mathrm{T}_{\mathrm{C}}$ cells a positive correlation with age only among the male patients $(n=5, r=0.9808, p=0.0032)$, within the CD20 ${ }^{+} T_{H}$ cells a non-significant positive correlation with age only among the female patients $(n=6$, $\mathrm{r}=0.7851, \mathrm{p}=0.0643$; data not shown). 

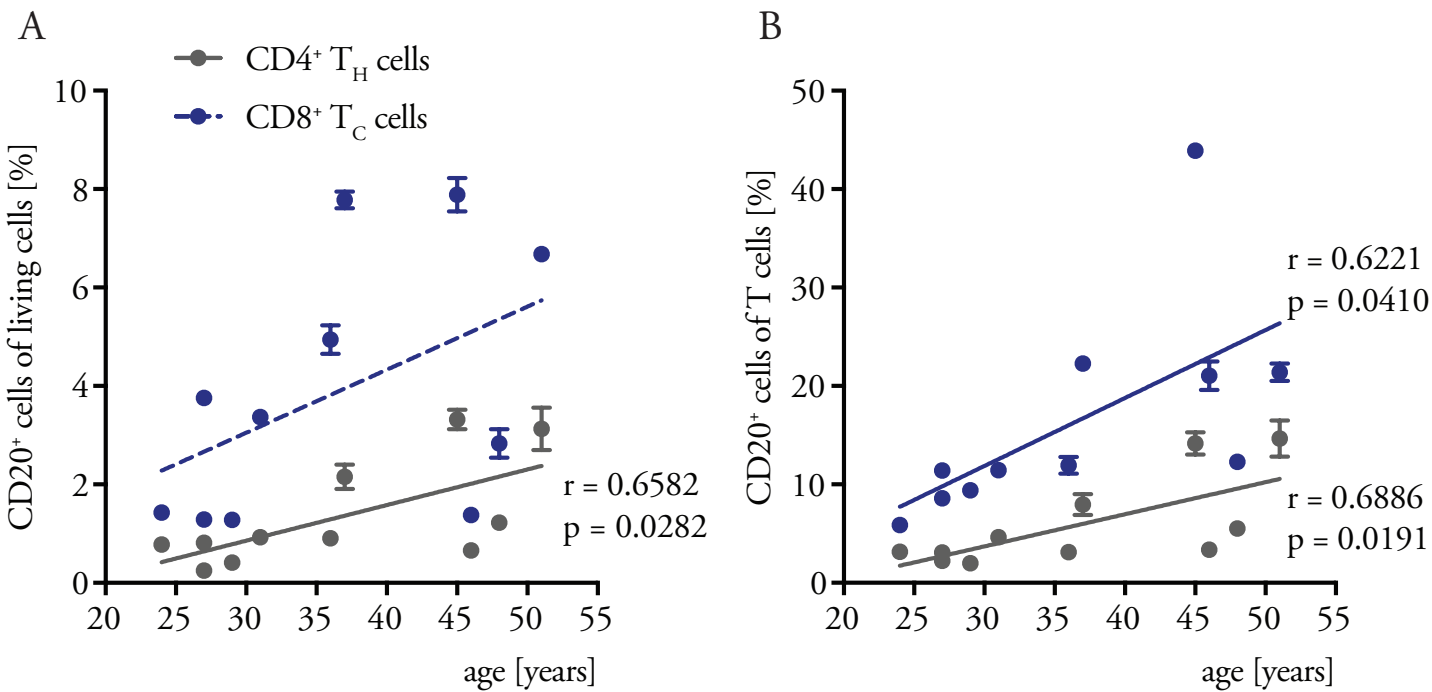

Figure 31. Correlation between frequencies of $\mathrm{CD} 20^{+} \mathrm{T}$ cells and age. The figure shows the frequencies of $\mathrm{CD} 20^{+} \mathrm{T}_{\mathrm{H}}$ and $\mathrm{T}_{\mathrm{C}}$ cells expressed as $\%$ of all living PBMCs (A) and of CD $4{ }^{+} / 8^{+}$cells (B) alongside with patients' age. Data is presented as mean \pm standard error of mean ( $\mathrm{n}=11$, linear regression, Pearson $\mathrm{r} ; \mathrm{A}-\mathrm{T}_{\mathrm{C}}$ : $\mathrm{p}=0.1391$ not shown in figure). 


\section{Discussion}

This dissertation aimed to characterize the effects of anti-CD20 mediated B cell depletion on $\mathrm{CD} 20^{+} \mathrm{B}$ and $\mathrm{T}$ cells and on other immune cell populations in MS patients during depletion and repletion.

Here, I was able to demonstrate that

1. the repleting $B$ cells replete pre-dominantly in a transitional and mature naïve phenotype, yet more activated, pro-inflammatory and with more potent co-stimulation capacities.

2. the small $\mathrm{CD} 20^{+} \mathrm{T}$ cell population, which is also depleted upon anti-CD20 therapy, doesn't show phenotype differences upon repletion, yet replete faster than the B cells.

3. the remaining $\mathrm{T}$ cells, and especially the $\mathrm{CD} 4^{+} \mathrm{T}_{\mathrm{H}}$ cells, show a loss of effector functions upon anti-CD20 therapy.

4. myeloid cells, on the other hand, vary in their reaction to the treatment, and show only little phenotype differences.

5. Patients' EDSS correlated with two main B cell subpopulations: naïve and memory B cells.

6. Regarding the question of patient selection for the treatment, patients could be classified into two distinct groups according to their B cell phenotype before anti-CD20 therapy.

\section{Aim 1: Direct effects of anti-CD20 depletion on $\mathrm{CD}^{+} 0^{+}$cells:}

B cells replete more activated after anti-CD20 depletion. Rituximab as a mean for CD20 depletion is not firstly used in MS, it is also applied in many other autoimmune diseases, such as rheumatoid arthritis, primary Sjögren's syndrome, anti-neutrophil cytoplasmic antibody (ANCA) associated vasculitis and different glomerulonephritis, as a mean to achieve clinical remission (Gürcan et al. 2009; Jayne 2010). As shown in this dissertation, the repleting $\mathrm{B}$ cells show a different phenotype than the ones before depletion. The repleting $\mathrm{B}$ cells are mostly transitional but also mature naïve $\mathrm{B}$ cells. The transitional $\mathrm{B}$ cells are the most mature $\mathrm{B}$ cells capable of migrating from the bone marrow into the periphery, indicating a repletion based on a new differentiation from the bone marrow. These cells show a more activated phenotype when compared with their phenotype before depletion. This is seen firstly in the elevated expression of the activation markers CD25, CD69 and CD95 (FAS). These finding come to some extent as a surprise. For example, CD25 is expressed by all B cells, but known to be expressed predominantly within the memory B cell pool. Brisslert et al. (2006) and Amu et al. (2007) have shown, that CD25 $\mathrm{B}$ cells in healthy controls as well as in patients with rheumatoid arthritis and systemic lupus erythematosus are pre-dominantly memory B cells $\left(\mathrm{CD} 27^{+}\right)$, morphologically larger and more granulated, proliferate to a greater extent as a response to IL-2, and are more efficient APCs than CD25 B cells. Nevertheless, In context with the phenotypical analysis above, I do not believe that the higher expression of CD25 is due to an elevated frequency of memory B cells in the repleting pool, but reflective of the fact that naïve, regrowing B cells are being activated in the process of re-population. This general observation confirms earlier experimental study by Häusler et al. (2018) showing that in the context of peripheral 
activation, B cells reappear with an enhanced pro-inflammatory molecular arsenal. As shown in Figure A2, the patients with a naive B cell phenotype before treatment showed a slightly elevated CD25 expression in comparison to the patients with a memory/balanced B cell phenotype. Secondly, the higher CD40 and CD86 expression indicate more potent co-stimulation capacities, which match the findings above. Similar results were also found by Leandro et al. (2006), Roll et al. (2006) and Pers et al. (2007) who have investigated the B cell repopulation after $\mathrm{CD} 20$ depletion with rituximab in other autoimmune diseases (rheumatoid arthritis, primary Sjögren's syndrome and others), and by Häusler et al. (2018), who investigated this re-population in EAE mice. On the other hand, Maurer et al. (2016) have found, that after a successful CD20 depletion, the remaining memory B cells who escaped depletion tend to undergo clonal expansion, and the patients replete therefore with a memory B cell phenotype. This could be explained by the findings of Häusler et al. (2018) who have shown, that anti-CD20 therapy has a limited efficiency on B cell depletion in the secondary lymphatic organs and in the bone marrow, where the remaining $\mathrm{CD}_{2} 0^{+} \mathrm{B}$ cells also showed a large $\mathrm{CD} 27^{+}$proportion.

With regard to the repletion phenotype, Leandro et al. (2006) have also found, that the patients with rheumatoid arthritis who relapsed during B cell repletion tented to replete with a higher frequency of memory B cells. This raises the issue of depletion efficiency, which according to Leandro (2013) is variable even when treated with the same dose. Reff et al. (1994) have shown, that a dosage dependent depletion exists, and that even though all B cells in peripheral blood were depleted, there was not a sufficient depletion in secondary lymphatic organs. Therefore, a sufficient dose which will prevent the survival of $\mathrm{CD} 27^{+}$memory B cells should be in my opinion chosen in order to prevent unwanted relapses during B cell repletion, as Kim et al. (2011) found.

The $\mathrm{CD} 20^{+} \mathrm{T}$ cells phenotype doesn't change upon anti-CD20 depletion. The existence and depletion potential of $\mathrm{CD}_{2} 0^{+} \mathrm{T}$ cells (and NK cells) is already known. This small population counts $5-10 \%$ of $\mathrm{T}$ cells, and $5-6 \%$ of living PBMCs. A study performed by Storie et al. (1995) in healthy controls showed that the CD20 dim expression was restricted to $\mathrm{CD} 20^{+} \mathrm{T}$ cells, whereas all $\mathrm{CD} 20^{+} \mathrm{B}$ cells were $\mathrm{CD} 20^{\text {bright }}$. They have also found, that the majority of these cells are $\mathrm{CD} 8^{+}$and $\mathrm{CD} 45 \mathrm{RO}^{+}$. I have found similar results, indicating a $\mathrm{CD} 8$ dominance among the $\mathrm{CD} 20^{+} \mathrm{T}$ cells, and a majority of CD45RO expression, but only among the $\mathrm{CD}^{+}$cells, indicating a memory phenotype. The majority of the $\mathrm{CD} 8^{+}$cells were

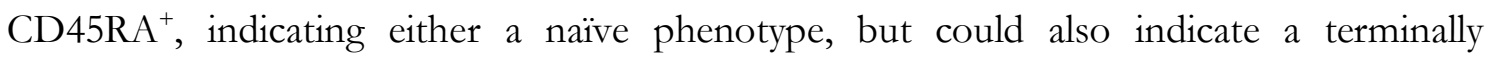
differentiated phenotype. Like Leandro et al. (2006) I have also found no differences in their phenotype at repletion.

In different individuals, $\mathrm{CD} 20^{+} \mathrm{T}$ cells show different dominance. Different studies to this theme preset contradiction. Leandro et al. (2006) and von Essen et al. (2019) found a CD4 dominance, Schuh et al. (2016) and Gingele et al. (2018) found like me a CD8 dominance. 
This raises the question: do certain people show a different $\mathrm{CD} 20^{+} \mathrm{T}$ cell phenotype, and if so, why?

$\mathrm{CD} 20^{+} \mathrm{T}$ cells replete faster than B cells and show increased frequency with age. I confirmed the results of the above mentioned studies in other autoimmune diseases, that the $\mathrm{CD} 20^{+} \mathrm{T}$ cells, and especially the $\mathrm{CD} 8^{+}$population, replete faster than the $\mathrm{B}$ cells. Schuh et al. (2016) have found, that in several MS patients, relapses occurred after administration of anti-CD20 therapy at time of $\mathrm{CD} 20^{+} \mathrm{T}$ cell repletion, yet in $\mathrm{B}$ cell absence. This raises not only the question of the pathogenetic role of these cells in disease development, but also raises the question of therapy intervals. Could those patients having a relapse at $\mathrm{CD} 20^{+} \mathrm{T}$ cell repletion present a unique pathogenesis involving $\mathrm{CD} 20^{+} \mathrm{T}$ cells? Could they be identified? If so, they could be candidate to an earlier depletion than other patients. This faster repletion raises questions on its own: do these cells differentiate like the $\mathrm{B}$ cells in the bone marrow and when mature enough migrate into the periphery, or do they differentiate in the periphery from $\mathrm{CD}^{-} 0^{-} \mathrm{T}$ cells, and if so why?

Regarding these questions, Schuh et al. (2016) also showed that the CD20 ${ }^{+} \mathrm{T}$ cells express the CD20 antigen after transcription and translation, indicating an endogen up-regulation of this marker. They were also able to find them in human primary (thymus and bone marrow) and secondary (adenoid) lymphatic tissue, in the thymus only within the mature, $\mathrm{CD} 4^{+}$or $\mathrm{CD}^{+}$medullary $\mathrm{T}$ cell population. The question remains: do these cells have a specific role and are consequently a distinct population with a distinct role? Storie et al. (1995) have found like me that the frequency of the $\mathrm{CD} 20^{+} \mathrm{T}$ cell compartment increases with age, and cannot be found for example in cord blood. This raises again the question of origin of these cells, since the capacity of the bone marrow to produce more naïve cells decreases with age.

\section{Aim 2: Indirect effects of anti CD20 depletion on CD20- cells:}

$\mathrm{CD}^{+}$and $\mathrm{CD}^{+} \mathrm{T}$ cells react alike to anti-CD20 depletion and show loss in effector function. It is interesting to see, that both $T$ cell populations, $T_{H}$ and $T_{C}$ cells, react similarly over time to $B$ cell depletion, yet the $T_{H}$ cells seem to be more affected that the others, most likely due to their close interaction with the B cells. Both show firstly a decrease in terminally differentiated cells (the $\mathrm{T}_{\mathrm{H}}$ larger than $\mathrm{T}_{\mathrm{C}}$ ), which could be explained through the increase in frequency of L-selectin positive cells which is seen at depletion and further at late repletion. This means that the $\mathrm{T}$ cells have a higher adhesion and rolling potential and therefore a higher migration potential. This could have two meanings: (1) a higher migration in the periphery and CNS and therefore increase in CNS inflammation or (2) a higher migration into the secondary lymphatic organs, mobilizing T cells away from the CNS, which in turn could have a positive effect on CNS inflammation. Sadly, we only analyzed the rolling potential of the $\mathrm{T}$ cells through L-selectin and not the actual migration capacity through integrin $\alpha 4 \beta 1$ (very late antigen-4), which is essential for $T$ cell migration through the BBB into the CNS. 
This increase in frequency of L-selectin expression, presented as decrease in frequency of terminally differentiated $\mathrm{T}$ cells, in the $\mathrm{CD} 4^{+}$compartment accompanied with slight increase in frequency of $\mathrm{T}_{\mathrm{EM}}$ cells, shows a decrease in the frequency of overall $\mathrm{T}$ cells with the highest immediate effector function, which also nest in the periphery and not in secondary lymphoid organs. This accompanied increased respectively constant frequency of $\mathrm{CD}^{+}{ }^{+}$respectively $\mathrm{CD}^{+} \mathrm{T}_{\mathrm{EM}}$ cells could indicate a higher potential for myeloid cells' activation. The $\mathrm{T}_{\mathrm{EM}}$ show a high effector function expressed among others in IFN- $\gamma$ secretion, which in turn activates macrophages, NK cells and other T cells.

Myeloid cells vary in their reaction to anti-CD20 depletion. The myeloid cells, as unspecific APCs seem to be less effected than the T cells from B cell absence. They show differences in activation, antigen presentation and cytokine secretion, but those changes normalize at B cell repletion, suggesting one of two things: (1) the myeloid cells do take the role of the $B$ cells in their absence (better antigen presentation, more IL-6 secretion), yet "give it back" at B cell re-appearance, (2) the B cells regulate myeloid cells' activation, and it therefore normalizes upon naïve B cell repletion. Lehmann-Horn et al. (2011) investigated the influence of anti-CD20 depletion on CD11b ${ }^{+}$APCs in EAE mice and in patients. They have found, that in B cell depleted mice the remaining CD11b ${ }^{+}$cells produced more TNF- $\alpha$ after depletion than before, and concluded that naïve B cells regulate APCs in an anti-inflammatory manner. They have also found, that compared to untreated control patients some B cell depleted patients presented a higher frequency of myeloid cells secreting TNF- $\alpha$, and the overall samples of the treated patients were also distributed over a wider range of values, reflecting a greater variability in the myeloid cells' reaction to anti-CD20 depletion.

In addition, Hauser et al. (2008), Clifford et al. (2011), Memon et al. (2018) and others have found, when compared with placebo groups, no higher risk of malignancies, opportunistic and serious infections (requiring hospitalization) not only among MS patients treated with rituximab but also among patients with other autoimmune diseases, for example rheumatoid arthritis. This could be explained due to the only small changes in $\mathrm{CD}^{+} \mathrm{T}$ cells' and myeloid cells' phenotype, maintaining a stable immune reaction against pathogens and against malignant cells, meaning that $B$ cell depletion does not cause a significant immunosuppression.

\section{Aim 3: Individualized MS therapy}

MS patients show with increasing age an increase in B cell count in peripheral blood, which only correlates with female patients. Morbach et al. (2010) have characterized the changes in $\mathrm{B}$ cells and in the B cell sub-populations from infancy to adulthood in healthy individuals, and so created reference values for these parameters. They have found, that the B cell count in peripheral blood of healthy individuals increases until the age of approximately 26 years of age, and then stabilizes until the age of 50. The MS patients in this study show generally a lower B cell count (reference for age of 26-50: 199 [169-271] cells/ $\mu \mathrm{l}$ blood), yet most still 
within the norm (100-500 cells/ $\mu$ l blood). This contradicts the findings of Habib et al. (2015), which have found an increase in $\mathrm{CD}_{1} 9^{+} \mathrm{B}$ cell counts in MS patients when compared to healthy controls. Moreover, the B cell count of the patients in this study positive correlates with age in total, and when looked at the value distribution between the two genders, one can only see a positive correlation only among the women, and not among the men. This is an interesting observation, for MS is known to affect more women than men. This is surprising, since in general the B cell compartment does not show a significant gender specific distribution (Kverneland et al. 2016). I thus hypothesize that the observed association relates to MS or autoimmunity in general. It is known that certain B cells sub-populations are more frequent in elderly women with autoimmune disorders than in young women, or men of any age. At this point, I can only speculate that the increase of the $\mathrm{B}$ cell counts with increasing age in women relates to an expansion of the reported B cell population (Rubtsova et al. 2012).

MS patients show two main B cell phenotypes: memory/balanced and naïve type. The two main B cell populations seen in peripheral blood are naïve and memory B cells. Duddy et al. (2007) have shown a more activated and pro-inflammatory profile, among others via secretion of pro-inflammatory cytokines, in memory than in naïve B cells, which almost exclusively secrete IL-10. This reinforces the findings of Souto-Carneiro et al. (2009) and Kappos et al. (2014). The former showed, that rheumatoid arthritis patients have decreased memory B cell frequency in peripheral blood compared with healthy controls, since they accumulate in the synovial tissue, contributing to the inflammation. The memory $\mathrm{B}$ cell frequency in peripheral blood of these patients increases after treatment with anti-TNF- $\alpha-m A b$ infliximab since TNF- $\alpha$ regulates this migration into the inflamed tissue. Because of therapy success in rheumatoid arthritis, it is assumed, that memory B cells contribute to the inflammation in the synovial tissue. The latter showed, that inhibiting the $\mathrm{B}$ cell differentiation with atacicept causes a relative increase in memory B cells and/or reduction in regulatory $\mathrm{B}$ cells, and by doing so worsens the clinical activity of MS. The involvement of memory B cell in MS pathogenesis points out even further when looking at the works of Hyrich (2004) and Titelbaum et al. (2005). Both reported of rheumatoid arthritis patients with no history of neurologic diseases showing both MS clinic and MRI activity consistent with demyelination after therapy with etanercept and infliximab. This raises the question: is there a marker only expressed by memory B cells, who could be used as a target for a memory $\mathrm{B}$ cell depletion?

I have found in all but one patient a strong correlation between the naïve and memory B cell frequencies and the EDSS score (which should be in light of the small number of patients addressed very cautiously), which led me as presented to classify all patients into two groups according to the dominant $\mathrm{B}$ cell population before therapy administration: memory/balanced type (which could be further classified in memory and in balanced type) and naïve type. As those cells differ in their phenotype, this raises the question: should some patient groups not be depleted? Surprisingly, I have found the patients with 
memory/balanced type to present a lower EDSS score than the other patients (demonstrating clinical meaning), yet large differences in T cell phenotype in the $\mathrm{CD}^{+}$and $\mathrm{CD}^{+}$compartment, which might not be beneficial for the patients (increase in $\mathrm{CD} 62 \mathrm{~L}$ expression) and in my opinion negative changes in myeloid cells phenotype (more IL-6 and TNF- $\alpha$, constant yet minor IL-10 secretion). On the other hand, the patients with naïve type show only changes in $\mathrm{CD}^{+} \mathrm{T}$ cells, unspecific changes in myeloid cells' antigen presentation and in my opinion positive changes in myeloid cells cytokine secretion (less IL- 6 and TNF- $\alpha$, constant increasing IL-10 secretion). Nevertheless, these negative changes in T cells of the patients with memory/balance type could also be positive. The increase in CD62L expression could mean as explained above more migration potential into the secondary lymphatic organs, mobilizing T cells away from the CNS and losing effector functions. A constant expression of this marker after depletion, as shown in the patients with naïve type could indicate a persistence of these effector functions and migration potential. As explained above, the naïve B cells also regulate myeloid APCs in an anti-inflammatory manner, and therefore their depletion might not be beneficial for the patients.

Nevertheless, all patients profited from the anti-CD20 therapy, since they did not develop new MRI lesions, didn't deteriorate in their EDSS score or had any relapses after therapy administration, even though they had different B cell phenotypes, meaning that these differences are not relevant for the indication for an anti-CD20 therapy. Yet some wonder, if patients should be constantly depleted of B cells, or whether an effect has been achieved through the depletion, which then can be maintained with a subsequent therapy, maintaining the clinical benefit.

According to the studies mentioned above and the changes described, the two patient groups should receive in case of therapy cessation in my opinion different immune therapies, since their $\mathrm{T}$ cells react differently to anti-CD20 depletion. The patients with memory/balanced type, whose $\mathrm{T}$ cells lose effector functions and migrate into the secondary lymphatic organs should receive a therapy that would leave those cells there, and away from the CNS. This could be, for example, Fingolimod, a sphingosine-1-phosphate receptor modulator keeping lymphocytes in the lymph nodes, and so preventing them from causing an inflammation in the CNS. The patients with naïve type, whose $\mathrm{T}$ cells show a persistence of effector functions should maybe receive a migration inhibiting therapy, in order to prevent further migration into the CNS. This could be, for example, natalizumab, an $\alpha 4$-integrin-mAb interfering with lymphocyte migration into the CNS, or a proliferation inhibitor, for example cladribine, a purine analogue which prevents the proliferation of rapid proliferating cells.

This raises further questions: (1) how come some patients show almost no change in $\mathrm{T}$ cell phenotype, and a persistence of effector functions despite clinical benefit? Could one identify a different B cell role in those patients compared to the others? (2) some patients don't profit from an anti-CD20 therapy. Could one identify them? How do their T cells react to the anti-CD20 therapy? 


\section{Summary}

This study was performed in order to better understand the effects of anti-CD20 depletion on the immune system of Multiple Sclerosis patients in light of the therapy success. Patients treated with the anti-CD20 antibody rituximab, as an off-label therapy option, and ocrelizumab, as approved therapy, for relapsing-remitting Multiple Sclerosis almost don't have new relapses or new magnetic resonance imaging lesions. Yet the long-term consequences of such therapy are still unknown. Taken together, I demonstrated not only the changes in B cell phenotype upon repletion, but also long-lasting changes in $\mathrm{T}$ cell phenotype as a response to B cell depletion and repletion. I was able to classify all patients into two main groups based on their B cell phenotype before depletion, and to show, that the $\mathrm{T}$ cells of these groups differ in their response to anti-CD20 depletion. I also suggested follow-up treatment options for every group, according to the changes in their $\mathrm{T}$ cell phenotype upon therapy, in case of treatment cessation.

Yet some questions remain open, and need to by further clarified. This study was designed mostly to investigate changes in antigen presenting cells' function of myeloid cells, and with very few $\mathrm{T}$ cell panels only. In my opinion a similar study should be performed with more T cell markers, which would be able to clarify the migration potential of these cells upon repletion. Furthermore, the $\mathrm{CD} 20^{+} \mathrm{T}$ cells could be further classified, and analyzed, I order to exclude disease activity. Such study should be in my opinion performed with more patients, in order to have enough patients with the three possible B cells phenotypes: naïve, balanced and memory type. Only then one could better analyze the differences in $\mathrm{T}$ cell phenotype upon anti-CD20 depletion dependent from the initial B cell phenotype.

When such differences are defined, and a possible follow up therapy is identified, one could try to cease therapy with anti-CD20 antibody, and start a maintenance therapy with, as suggested in the discussion, Fingolimod/natalizumab or cladribine. 


\section{Supplement}

\subsection{Certificate - TBNK classification}

\section{R INSTAND}

\section{ZERTIFIKAT}

Ringversuch vom 21.03.2018

Sie haben die Anforderungen des Ringversuchs mit den folgenden Untersuchungen erfüllt

Hämatologie 10 - Immunphänotypisierung 01 (213):

Gültigkeitsdauer 12 Monate:

B-Lymphozyten

CD4 pos. Lymphozyten mit CD3-Expression (\%)

CD4 pos. Lymphozyten mit CD3-Expression (/nl)

CD8 pos. Lymphozyten mit CD3-Expression

NK-Zellen ohne CD3-Expression

T-Lymphozyten

6429

Dr. med. Lutz Binder

Universitätsmedizin Göttingen

Georg-August-Universität

UMG-Labor

Robert-Koch Str. 40

37075 Göttingen

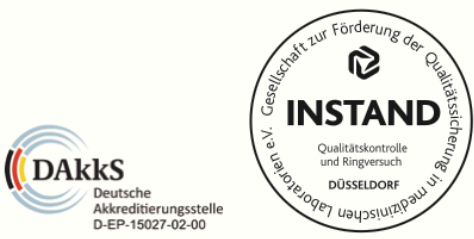

Düsseldorf, 19.04.2018
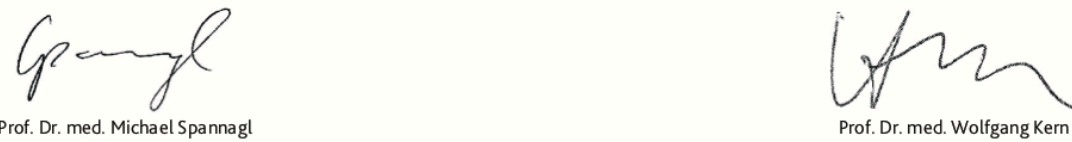

Prof. Dr. med. Michael Spanna (Leiter der Referenzinstitution) (Ringversuchsleiter) 


\subsection{Correlation between naïve and memory $B$ cell frequencies and} age

A

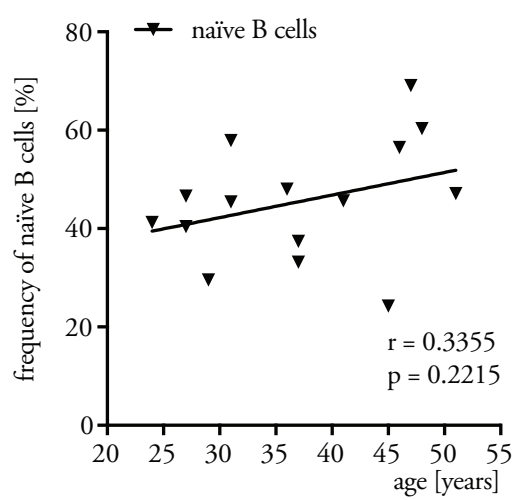

C

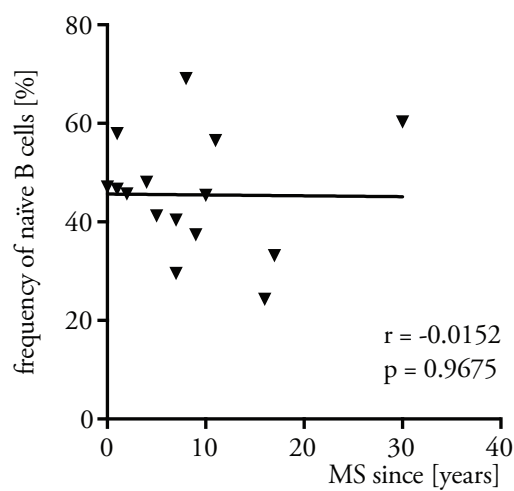

B

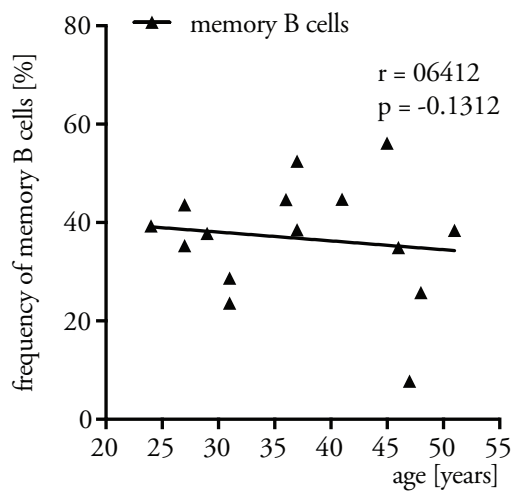

$\mathrm{D}$

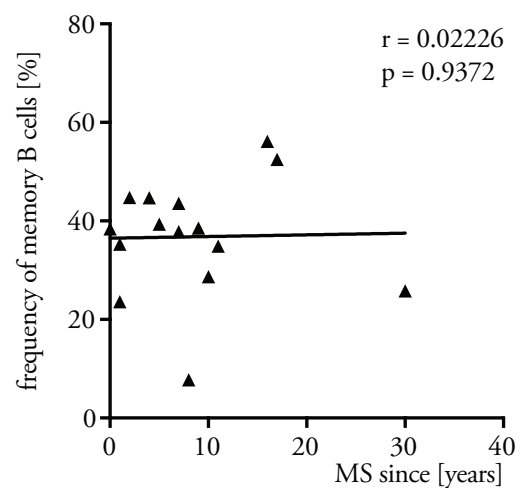

Figure A1. Correlation between naïve and memory B cell frequencies and age. The figure shows the frequency of naïve (A), memory (B) B cells expressed as \% of $\mathrm{CD} 19^{+}$cells, both before depletion, and the ratio naïve/memory $(\mathrm{C})$ and patients' age at time of first administration of anti-CD20 therapy $(\mathrm{n}=15$, linear regression, Pearson $\mathrm{r})$.

\subsection{Data to different B cell activation, APC function and cytokine phenotype among the two patient groups}

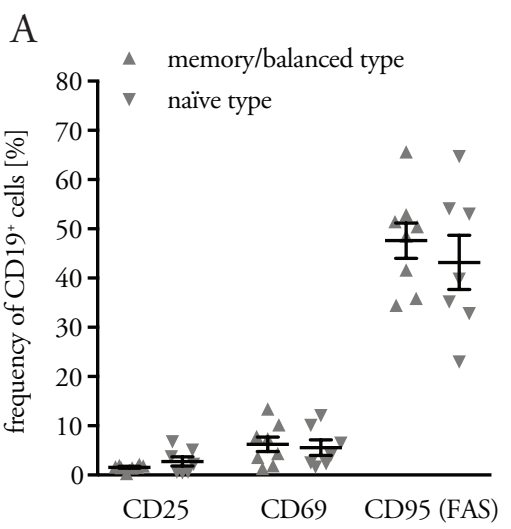

$\mathrm{B}$

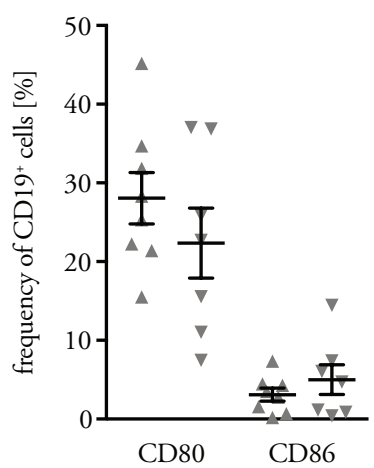

C

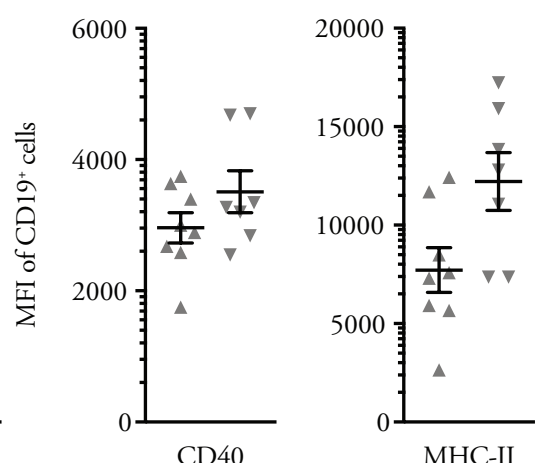

Figure A2. Differences in B cell activation phenotype between memory/balanced and naïve type. The figure shows the frequencies of (A) $\mathrm{CD}_{25} 5^{+} \mathrm{CD} 69^{+}$, and $\mathrm{CD} 95(\mathrm{FAS})^{+},(\mathrm{B}) \mathrm{CD} 80^{+}$and 
$\mathrm{CD} 6^{+}$cells expressed as \% of CD19+ B cells and (C) MFIs of CD40 and MHC-II of CD19+ B cells all upon $\mathrm{CpG}$ stimulation $[2 \mu \mathrm{g} / \mathrm{ml}]$ before B cell depletion. Data to frequencies of $\mathrm{CD}^{4} 0^{+}$and MHC-II+ B cells, as shown in Figure 7, demonstrate a ubiquitous expression of said surface antigens.

Data is presented as mean \pm standard error of mean ( $n=8 / 7$; unpaired t-test/Mann-Whitney-U-Test: ns unless otherwise stated).

A

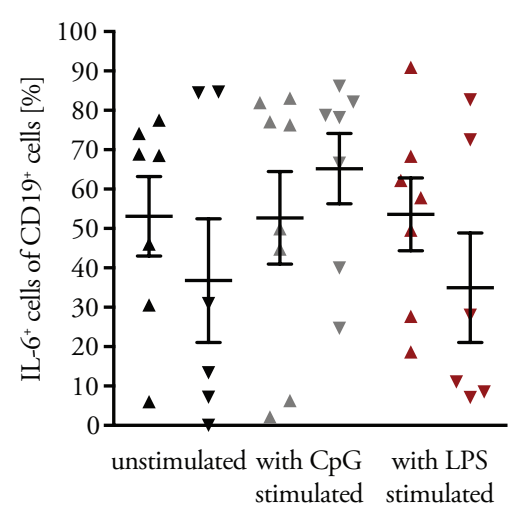

C

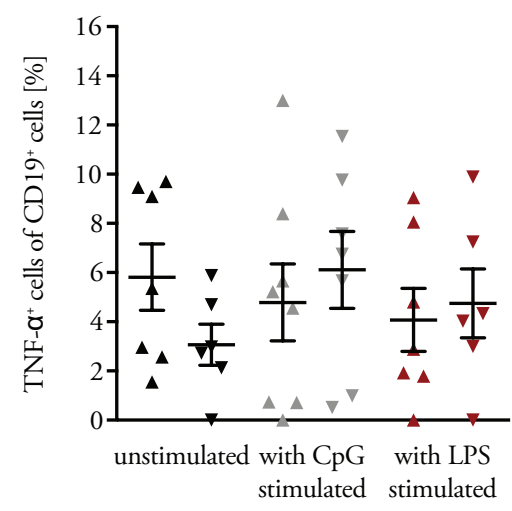

B

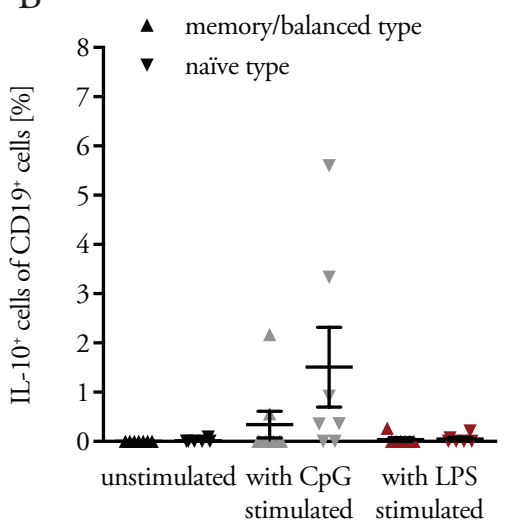

Figure A3. Differences in B cell cytokine phenotype between memory/balanced and naïve type. The figure shows the frequencies of $\mathrm{IL}_{-} 6^{+}(\mathrm{A}), \mathrm{IL}_{-}-10^{+}$(B) and $\mathrm{TNF}-\alpha^{+}(\mathrm{C})$ expressed as $\%$ of CD19+ B cells unstimulated, upon CpG $[1 \mu \mathrm{g} / \mathrm{ml}]$ and LPS $[500 \mathrm{pg} / \mathrm{ml}]$ stimulation as shown in Table 11 before $B$ cell depletion. Data is presented as mean \pm standard error of mean $(n=8 / 7$; unpaired t-test/Mann-Whitney-U-Test: ns unless otherwise stated). 


\subsection{Data to different cell phenotypes among the two patient groups}

\subsubsection{Data to $\mathrm{CD}^{+}{ }^{+} \mathrm{T}_{\mathrm{H}}$ cells}
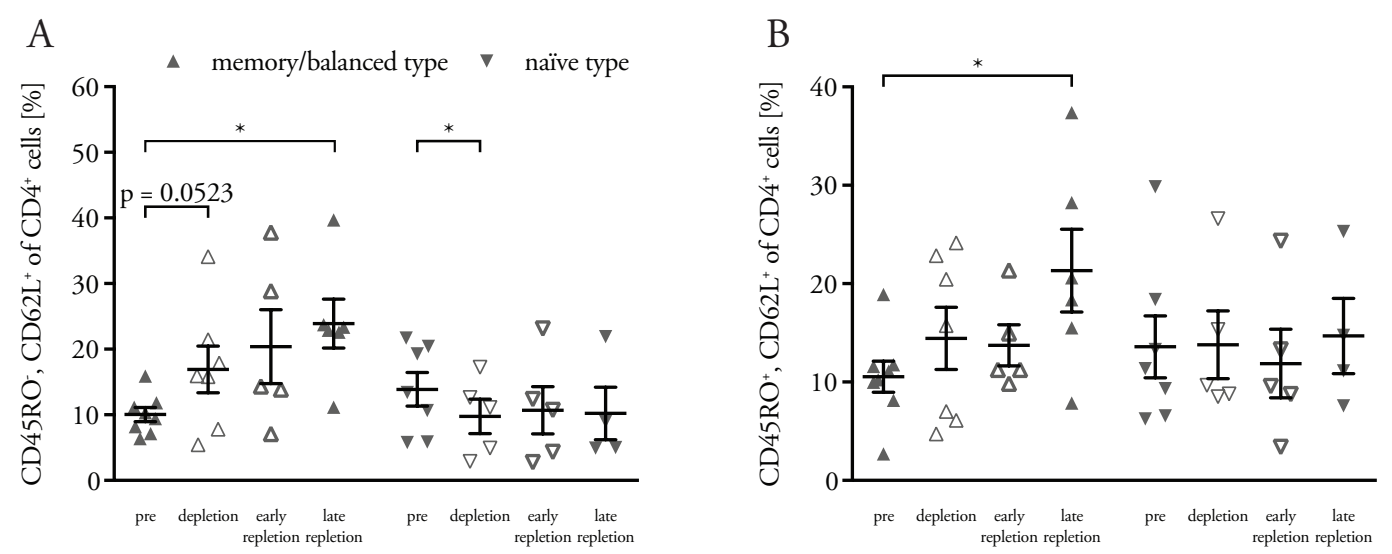

C

$\mathrm{D}$
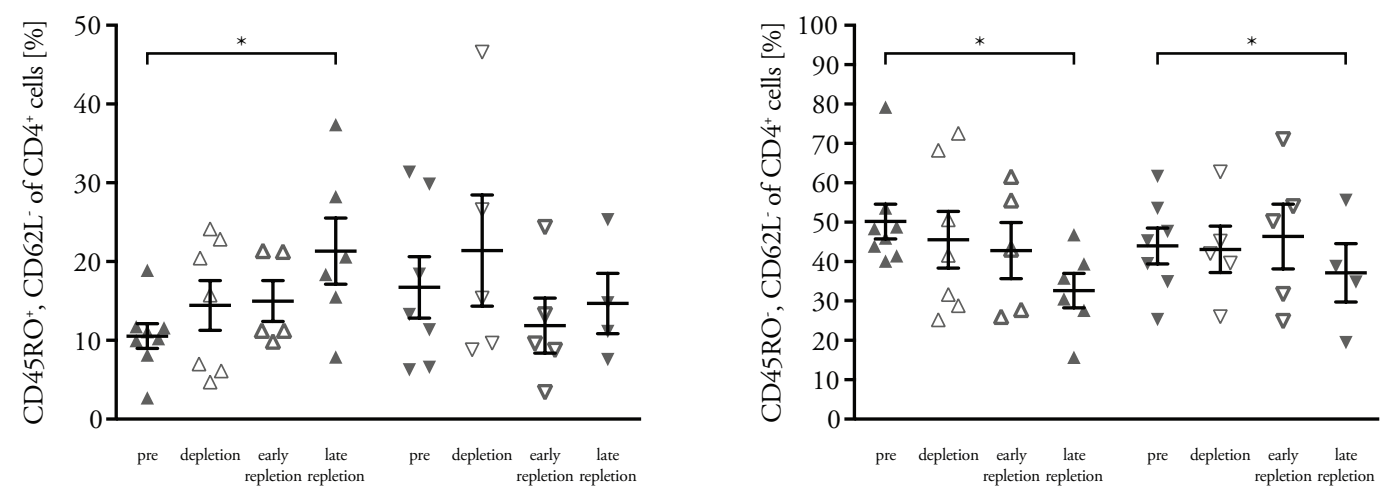

$\mathrm{E}$

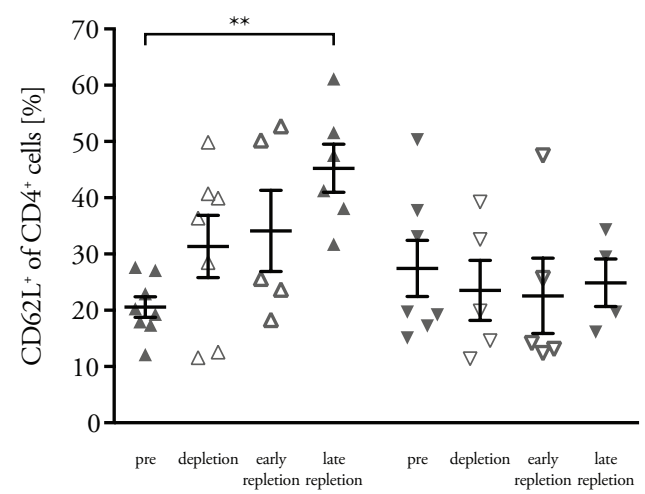

Figure A4. Differences in $\mathrm{CD}^{+} \mathrm{T}_{\mathrm{H}}$ cells maturation and CD62L expression phenotype between memory/balanced and naïve type. The figure shows the frequencies of naïve (A), central memory (B), effector memory (C) and terminally differentiated (D) $\mathrm{T}_{\mathrm{H}}$ cells as well as frequencies of CD62 $\mathrm{L}^{+} \mathrm{T}_{\mathrm{H}}$ cells (E) expressed as \% of $\mathrm{CD}^{+}$cells through four selected samples representing four selected time points for every patient. Data is presented as mean \pm standard error of mean ( $\mathrm{n}=8 / 7 / 5 / 6, \mathrm{n}=7 / 5 / 5 / 4$; paired $\mathrm{t}$-test/Wilcoxon matched-pairs signed rank test: ns unless otherwise stated). 


\subsubsection{Data to $\mathrm{CD8}^{+} \mathrm{T}_{\mathrm{C}}$ cells}
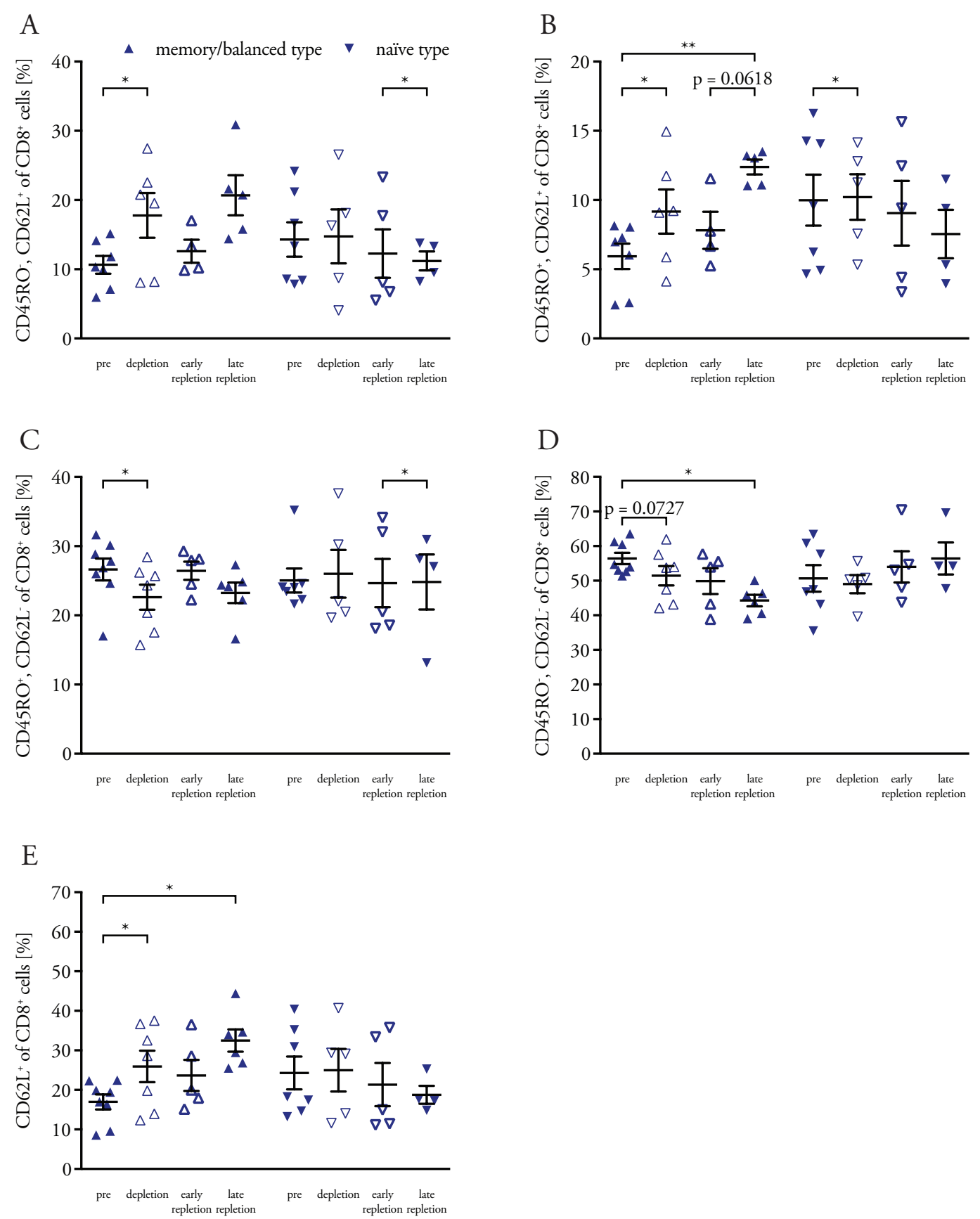

Figure A5. Differences in $\mathrm{CD}^{+} \mathrm{T}_{\mathrm{C}}$ cells maturation and CD62L expression phenotype between memory/balanced and naïve type. The figure shows the frequencies of naïve (A), central memory (B), effector memory (C) and terminally differentiated (D) $\mathrm{T}_{C}$ cells as well as frequencies of CD62 $\mathrm{L}^{+} \mathrm{T}_{\mathrm{C}}$ cells (E) expressed as \% of $\mathrm{CD} 8{ }^{+}$cells through four selected samples representing four selected time points for every patient. Data is presented as mean \pm standard error of mean $(n=8 / 7 / 5 / 6$, $\mathrm{n}=7 / 5 / 5 / 4$; paired t-test/Wilcoxon matched-pairs signed rank test: ns unless otherwise stated; memory $/$ balanced type: $\mathrm{T}_{\mathrm{N}}$ pre-late repletion $\mathrm{p}=0.0333$, $\mathrm{T}_{\mathrm{EM}}$ pre-late repletion $\mathrm{p}=0.0314$, all after Bonferroni-Holm correction: ns). 


\subsubsection{Data to $\mathrm{CD}_{14}^{+}$myeloid cells}
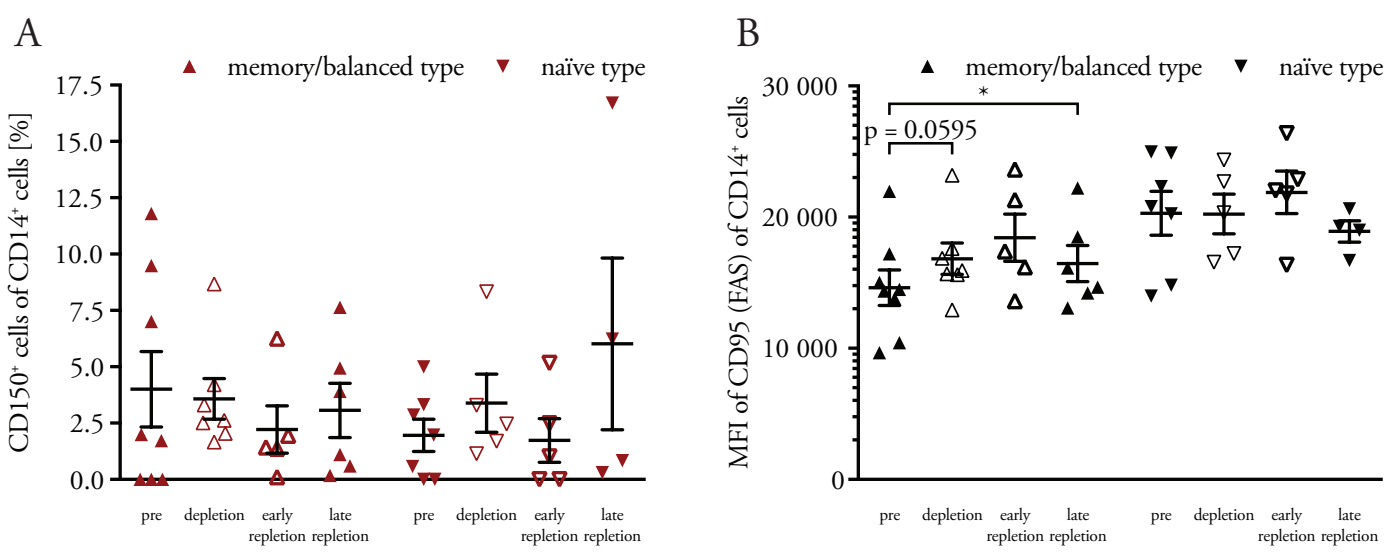

C

\section{$\mathrm{D}$}
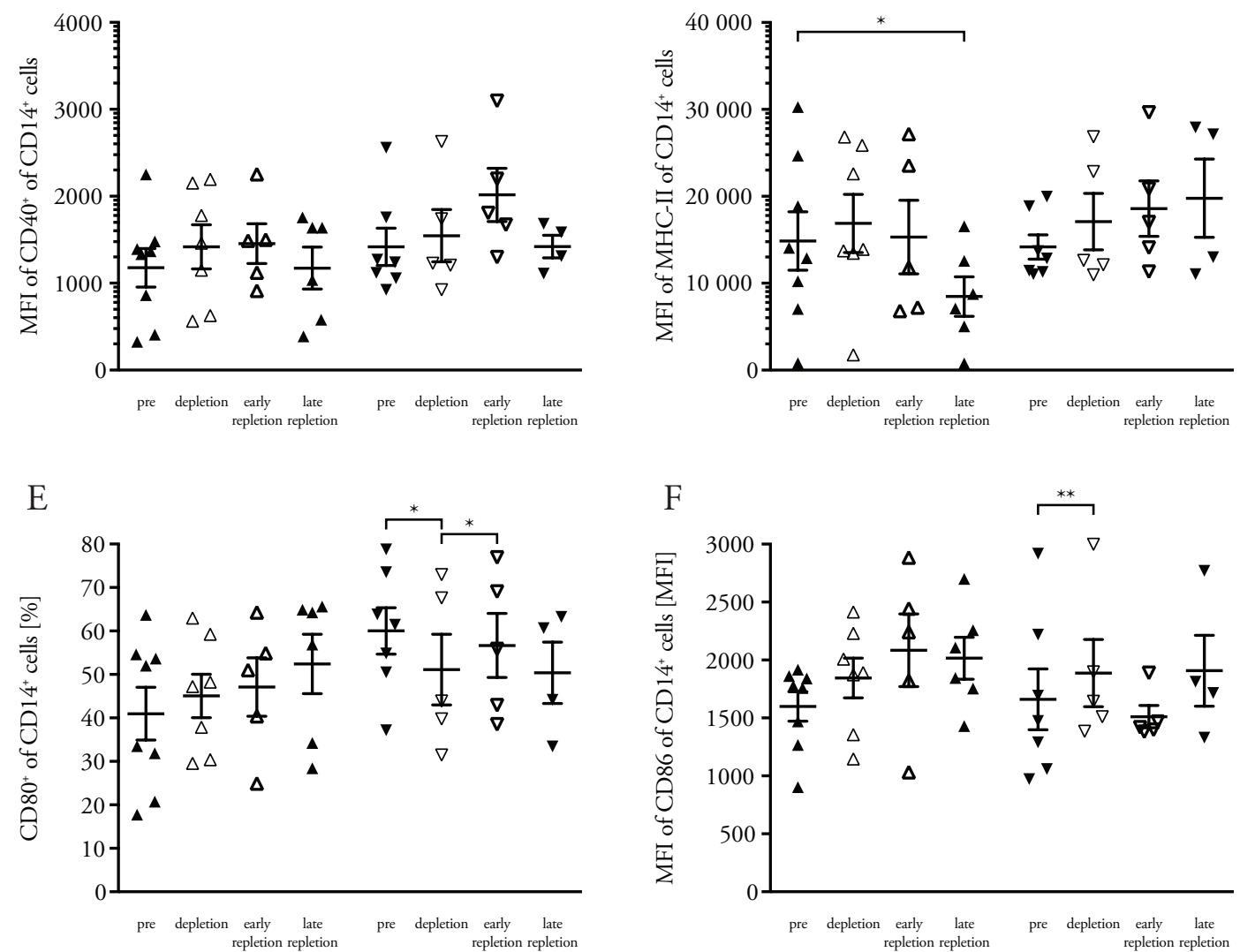

Figure A6. Differences in $\mathrm{CD}^{+} 4^{+}$myeloid cells activation and APC phenotype between memory/balanced and naive type. The figure shows the frequencies of $\mathrm{CD} 150^{+}$(A) myeloid cells upon LPS stimulation $[100 \mathrm{pg} / \mathrm{ml}]$ as shown in Table 11, and CD80+(E) myeloid cells both expressed as $\%$ of $\mathrm{CD}_{14}{ }^{+}$cells, MFIs of CD $95(\mathrm{FAS})^{+}(\mathrm{B}), \mathrm{CD} 40^{+}(\mathrm{C})$ and $\mathrm{MHC}-\mathrm{II}^{+}$(D) and $\mathrm{CD}^{+} 6^{+}(\mathrm{F})$ myeloid cells through four selected samples representing four selected time points for every patient. Data is presented as mean \pm standard error of mean ( $n=8 / 7 / 5 / 6, n=7 / 5 / 5 / 4$; paired $\mathrm{t}$-test/Wilcoxon matched-pairs signed rank test: ns unless otherwise stated). 


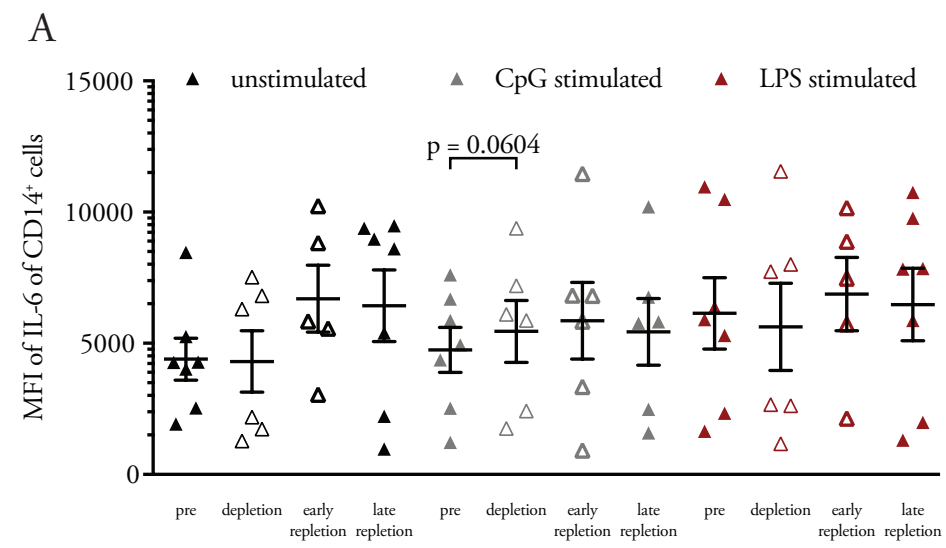

B

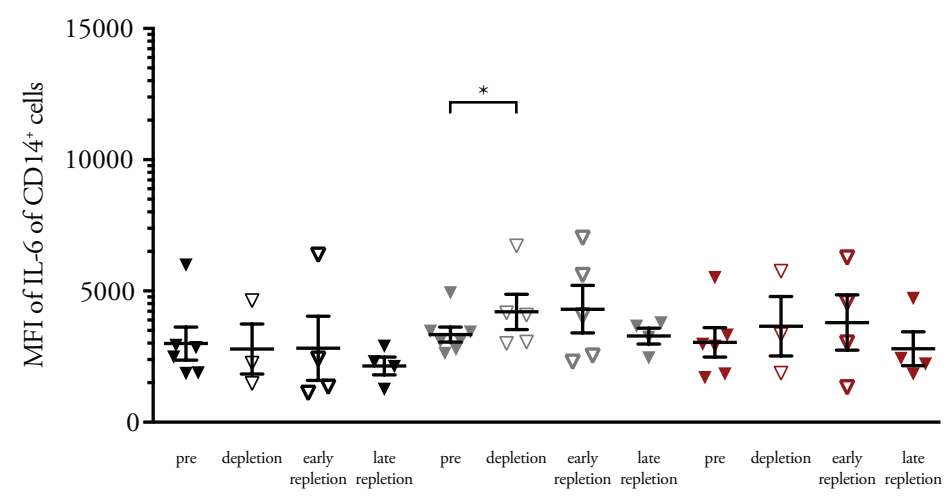

C

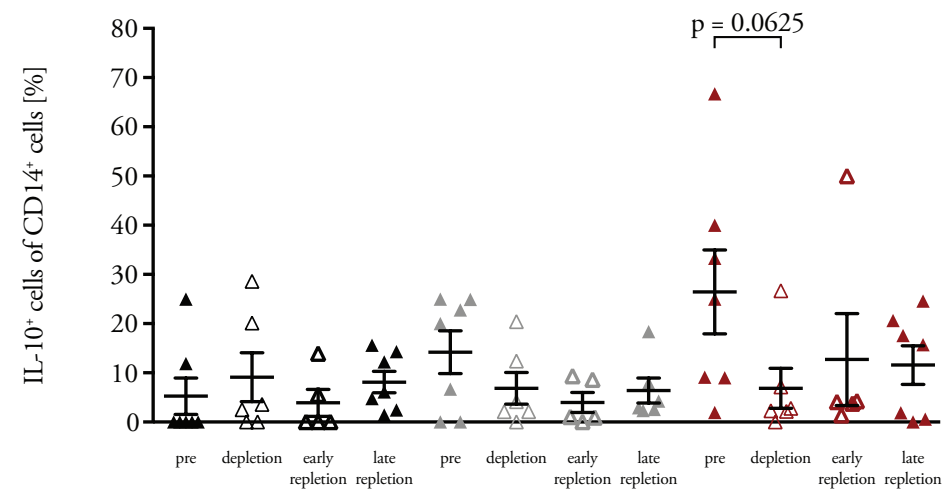

$\mathrm{D}$

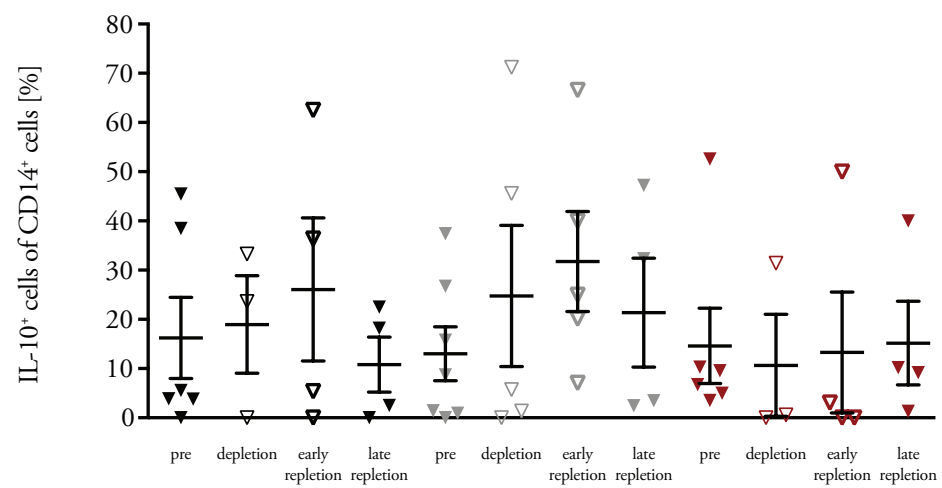

Figure A7. Differences in $\mathrm{CD}_{14}{ }^{+}$myeloid cells cytokine phenotype between memory/balanced and naïve type I. The figure shows the MFIs of $\operatorname{IL}_{-} 6^{+}$(A, B) and frequencies of $\mathrm{IL}_{-1} 0^{+}$(C, D) myeloid cells expressed as \% of CD14+ cells unstimulated, upon CpG $[1 \mu \mathrm{g} / \mathrm{ml}]$ and LPS $[500 \mathrm{pg} / \mathrm{ml}]$ stimulation as shown in Table 11 through four selected samples representing four selected time points 
for every patient. Figures A, C show the data for the patients with memory/balanced type, B, D for naïve type. Data is presented as mean \pm standard error of mean ( $\mathrm{n}=7 / 6 / 5 / 6,7, n=7,6 / 5,3 / 5,4 / 4$; paired t-test/Wilcoxon matched-pairs signed rank test: ns unless otherwise stated).

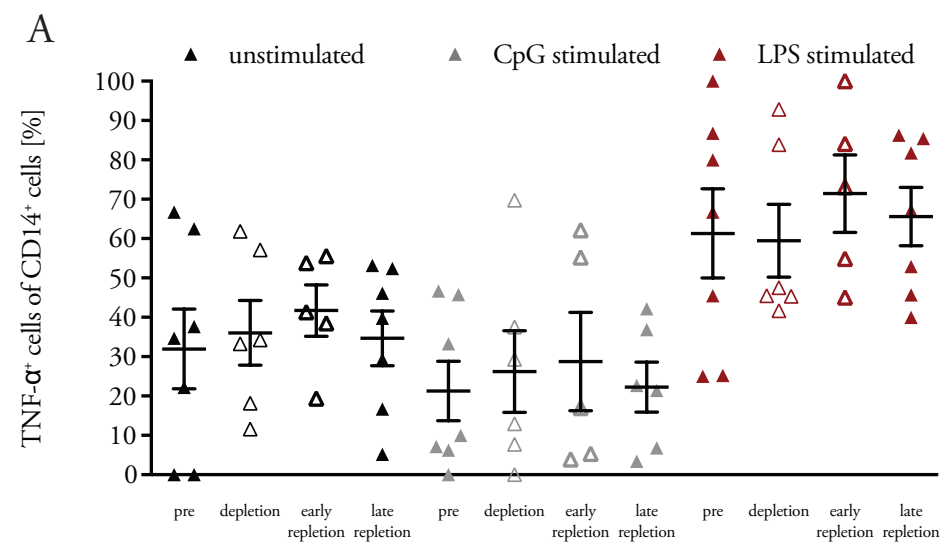

B

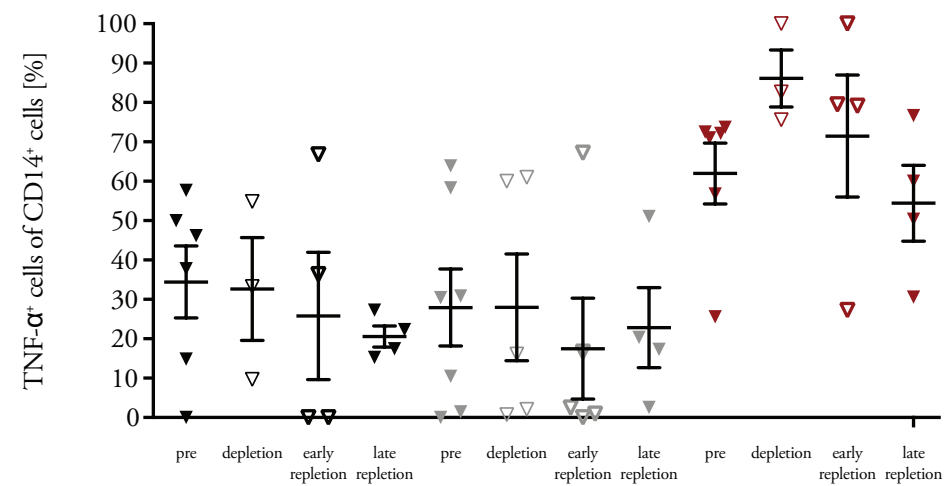

Figure A8. Differences in CD14+ myeloid cells cytokine phenotype between memory/balanced and naïve type II. The figure shows the frequencies of TNF- $\alpha^{+}$myeloid cells expressed as $\%$ of CD $14^{+}$ cells unstimulated, upon CPG $[1 \mu \mathrm{g} / \mathrm{ml}]$ and LPS $[500 \mathrm{pg} / \mathrm{ml}$ stimulation as shown in Table 11 through four selected samples representing four selected time points for every patient. Figure A show the data for the patients with memory/balanced type, B for naïve type. Data is presented as mean \pm standard error of mean ( $\mathrm{n}=7 / 6 / 5 / 6,7, \mathrm{n}=7,6 / 5,3 / 5,4 / 4$; paired $\mathrm{t}$-test/Wilcoxon matched-pairs signed rank test: ns unless otherwise stated). 


\section{$7 \quad$ References}

Agrawal S, Gupta S (2011): TLR1/2, TLR7, and TLR9 signals directly activate human peripheral blood naive and memory b cell subsets to produce cytokines, chemokines, and hematopoietic growth factors. J Clin Immunol $\underline{31}, 89-98$

Ai W, Li H, Song N, Li L, Chen H (2013): Optimal method to stimulate cytokine production and its use in immunotoxicity assessment. Int J Environ Res Public Health 10, 3834-3842

Amu S, Tarkowski A, Dörner T, Bokarewa M, Brisslert M (2007): The human immunomodulatory $\mathrm{cd} 25+\mathrm{b}$ cell population belongs to the memory b cell pool: Immunomodulatory CD25+ memory B cells. Scand J Immunol $\underline{66}, 77-86$

Arenas-Ramirez N, Woytschak J, Boyman O (2015): Interleukin-2: Biology, design and application. Trends Immunol $\underline{36}, 763-777$

Ascherio A, Munger KL (2007): Environmental risk factors for multiple sclerosis. Part I: The role of infection. Ann Neurol 61, 288-299

Ascherio A, Munger K (2016): Epidemiology of multiple sclerosis: From risk factors to prevention-an update. Semin Neurol $\underline{36}, 103-114$

Ascherio A, Munger KL, Lennette ET, Spiegelman D, Hernán MA, Olek MJ, Hankinson SE, Hunter DJ (2001): Epstein-Barr virus antibodies and risk of multiple sclerosis: A prospective study. JAMA 286, 3083-3088

Bach J-F (2002): The effect of infections on susceptibility to autoimmune and allergic diseases. N Engl J Med 347, 911-920

Banks WA, Kastin AJ, Gutierrez EG (1994): Penetration of interleukin-6 across the murine blood-brain barrier. Neurosci Lett 179, 53-56

Bar-Or A (2003): Analyses of all matrix metalloproteinase members in leukocytes emphasize monocytes as major inflammatory mediators in multiple sclerosis. Brain 126, 2738-2749

Barr TA, Shen P, Brown S, Lampropoulou V, Roch T, Lawrie S, Fan B, O'Connor RA, Anderton SM, Bar-Or A, et al. (2012): B cell depletion therapy ameliorates autoimmune disease through ablation of IL-6-producing B cells. J Exp Med 209, 1001-1010

Barun B, Bar-Or A (2012): Treatment of multiple sclerosis with anti-CD20 antibodies. Clin Immunol Orlando Fla 142, 31-37

Bastard JP, Jardel C, Delattre J, Hainque B, Bruckert E, Oberlin F (1999): Evidence for a link between adipose tissue interleukin-6 content and serum. Circulation $\underline{99}$, 2221-2222

Beltran E, Obermeier B, Moser M, Coret F, Simo-Castello M, Bosca I, Perez-Miralles F, Villar LM, Senel M, Tumani H, et al. (2014): Intrathecal somatic hypermutation of IgM in multiple sclerosis and neuroinflammation. Brain J Neurol 137, 2703-2714

Berer K, Mues M, Koutrolos M, Rasbi ZA, Boziki M, Johner C, Wekerle H, Krishnamoorthy G (2011): Commensal microbiota and myelin autoantigen cooperate to trigger autoimmune demyelination. Nature $\underline{479}, 538$

Bielekova B, Sung M-H, Kadom N, Simon R, McFarland H, Martin R (2004): Expansion and functional relevance of high-avidity myelin-specific CD4+ T cells in multiple sclerosis. J Immunol 172, 3893-3904 
Bittner S, Ruck T, Wiendl H, Grauer OM, Meuth SG (2017): Targeting B cells in relapsing-remitting multiple sclerosis: From pathophysiology to optimal clinical management. Ther Adv Neurol Disord 10, 51-66

Brisslert M, Bokarewa M, Larsson P, Wing K, Collins LV, Tarkowski A (2006): Phenotypic and functional characterization of human CD25+ B cells. Immunology $117,548-557$

Brodin P, Jojic V, Gao T, Bhattacharya S, Angel CJL, Furman D, Shen-Orr S, Dekker CL, Swan GE, Butte AJ, et al. (2015): Variation in the human immune system is largely driven by non-heritable influences. Cell $\underline{160}, 37-47$

Browne P, Chandraratna D, Angood C, Tremlett H, Baker C, Taylor BV, Thompson AJ (2014): Atlas of multiple sclerosis 2013: A growing global problem with widespread inequity. Neurology $\underline{83}, 1022-1024$

Brück W, Gold R, Lund BT, Oreja-Guevara C, Prat A, Spencer CM, Steinman L, Tintoré M, Vollmer TL, Weber MS, et al. (2013): Therapeutic decisions in multiple sclerosis: Moving beyond efficacy. JAMA Neurol $\underline{70}, 1315-1324$

Buckner JH (2010): Mechanisms of impaired regulation by CD4+CD25+FOXP3+ regulatory T cells in human autoimmune diseases. Nat Rev Immunol 10, 849-859

Buljevac D, Hop WCJ, Reedeker W, Janssens ACJW, van der Meché FGA, van Doorn PA, Hintzen RQ (2003): Self reported stressful life events and exacerbations in multiple sclerosis: Prospective study. BMJ $\underline{327}, 646$

Cambiaggi C, Scupoli MT, Cestari T, Gerosa F, Carra G, Tridente G, Accolla RS (1992): Constitutive expression of CD69 in interspecies T-cell hybrids and locus assignment to human chromosome 12. Immunogenetics $\underline{36}, 117-120$

Cantorna MT, Snyder L, Lin Y-D, Yang L (2015): Vitamin D and 1,25(OH)2D regulation of T cells. Nutrients , 3011-3021

Cao Y, Goods BA, Raddassi K, Nepom GT, Kwok WW, Love JC, Hafler DA (2015): Distinct inflammatory profiles of myelin-reactive $\mathrm{T}$ cells from patients with multiple sclerosis. Sci Transl Med 7, 287ra74

Carswell R: Pathological anatomy: Illustrations of the elementary forms of disease. Longman, Orme, Brown, Green and Longman 1838

Clifford DB, Ances B, Costello C, Rosen-Schmidt S, Andersson M, Parks D, Perry A, Yerra R, Schmidt R, Alvarez E, Tyler KL (2011): Rituximab-associated progressive multifocal leukoencephalopathy in rheumatoid arthritis. Arch Neurol 68, 1156-1164

Compston A, Coles A (2008): Multiple sclerosis. The Lancet 372, 1502-1517

Compston A, Confavreux C, Lassmann H, McDonald I, Miller D, Noseworthy J, Smith K, Wekerle $\mathrm{H}$ (Hrsg.): McAlpine's multiple sclerosis (fourth edition). Churchill Livingstone, Edinburgh 2006

Cotran RS, Kumar V, Collins T, Robbins SL: Robbins pathologic basis of disease. Saunders, Philadelphia 1999

Cross AH, Stark JL, Lauber J, Ramsbottom MJ, Lyons J-A (2006): Rituximab reduces B cells and T cells in cerebrospinal fluid of multiple sclerosis patients. J Neuroimmunol 180, 63-70 
Dantzer R, O'Connor JC, Freund GG, Johnson RW, Kelley KW (2008): From inflammation to sickness and depression: When the immune system subjugates the brain. Nat Rev Neurosci $\underline{9}, 46-56$

Dua T, Rompani P, World Health Organization, Multiple Sclerosis International Federation (Hrsg.): Atlas: Multiple sclerosis resources in the world, 2008. World Health Organization, Geneva, Switzerland 2008

Duddy M, Niino M, Adatia F, Hebert S, Freedman M, Atkins H, Kim HJ, Bar-Or A (2007): Distinct effector cytokine profiles of memory and naive human B cell subsets and implication in multiple sclerosis. J Immunol $\underline{178}$, 6092-6099

Elliott C, Lindner M, Arthur A, Brennan K, Jarius S, Hussey J, Chan A, Stroet A, Olsson T, Willison $\mathrm{H}$, et al. (2012): Functional identification of pathogenic autoantibody responses in patients with multiple sclerosis. Brain 135, 1819-1833

Farina C, Theil D, Semlinger B, Hohlfeld R, Meinl E (2004): Distinct responses of monocytes to Toll-like receptor ligands and inflammatory cytokines. Int Immunol 16, 799-809

Feinstein A, Freeman J, Lo AC (2015): Treatment of progressive multiple sclerosis: What works, what does not, and what is needed. Lancet Neurol 14, 194-207

Fischer HJ, Finck TLK, Pellkofer HL, Reichardt HM, Lühder F (2019): Glucocorticoid therapy of multiple sclerosis patients induces anti-inflammatory polarization and increased chemotaxis of monocytes. Front Immunol 10, 1200

Friese MA, Schattling B, Fugger L (2014): Mechanisms of neurodegeneration and axonal dysfunction in multiple sclerosis. Nat Rev Neurol 10, 225

Frischer JM, Bramow S, Dal-Bianco A, Lucchinetti CF, Rauschka H, Schmidbauer M, Laursen H, Sorensen PS, Lassmann H (2009): The relation between inflammation and neurodegeneration in multiple sclerosis brains. Brain $\underline{132}$, 1175-1189

Gardiner-Garden M, Frommer M (1987): CpG islands in vertebrate genomes. J Mol Biol 196, 261-282

Genain CP, Cannella B, Hauser SL, Raine CS (1999): Identification of autoantibodies associated with myelin damage in multiple sclerosis. Nat Med $\underline{5}, 170-175$

Gingele S, Jacobus T, Konen F, Hümmert M, Sühs K-W, Schwenkenbecher P, Ahlbrecht J, Möhn N, Müschen L, Bönig L, et al. (2018): Ocrelizumab depletes CD20+ T cells in multiple sclerosis patients. Cells $\underline{8}, 12$

Gürcan HM, Keskin DB, Stern JNH, Nitzberg MA, Shekhani H, Ahmed AR (2009): A review of the current use of rituximab in autoimmune diseases. Int Immunopharmacol 9, 10-25

Habib J, Deng J, Lava N, Tyor W, Galipeau J (2015): Blood B cell and regulatory subset content in multiple sclerosis patients. J Mult Scler 2,2

Haghikia A, Hohlfeld R, Gold R, Fugger L (2013): Therapies for multiple sclerosis: Translational achievements and outstanding needs. Trends Mol Med 19, 309-319

Hauser SL, Waubant E, Arnold DL, Vollmer T, Antel J, Fox RJ, Bar-Or A, Panzara M, Sarkar N, Agarwal S, et al. (2008): B-cell depletion with rituximab in relapsing-remitting multiple sclerosis. N Engl J Med 358, 676-688 
Häusler D, Häusser-Kinzel S, Feldmann L, Torke S, Lepennetier G, Bernard CCA, Zamvil SS, Brück W, Lehmann-Horn K, Weber MS (2018): Functional characterization of reappearing B cells after anti-CD20 treatment of CNS autoimmune disease. Proc Natl Acad Sci 115, 9773-9778

Hawker K, O'Connor P, Freedman MS, Calabresi PA, Antel J, Simon J, Hauser S, Waubant E, Vollmer T, Panitch H, et al. (2009): Rituximab in patients with primary progressive multiple sclerosis: Results of a randomized double-blind placebo-controlled multicenter trial. Ann Neurol 66, 460-471

Hayes CE, Hubler SL, Moore JR, Barta LE, Praska CE, Nashold FE (2015): Vitamin D actions on CD4(+) T cells in autoimmune disease. Front Immunol $\underline{6}, 100$

Hellings N, Barée M, Verhoeven C, D’hooghe MB, Medaer R, Bernard CCA, Raus J, Stinissen P (2001): T-cell reactivity to multiple myelin antigens in multiple sclerosis patients and healthy controls. J Neurosci Res $\underline{63}, 290-302$

Hernan MA, Olek MJ, Ascherio A (2001): Cigarette smoking and incidence of multiple sclerosis. Am J Epidemiol 154, 69-74

Hohlfeld R, Dornmair K, Meinl E, Wekerle H (2016): The search for the target antigens of multiple sclerosis, part 2: CD8+ T cells, B cells, and antibodies in the focus of reverse-translational research. Lancet Neurol 15, 317-331

Holmes N (2006): CD45: all is not yet crystal clear. Immunology 117, 145-155

Hyrich KL (2004): Anti-tumour necrosis factor therapy in rheumatoid arthritis: An update on safety. Ann Rheum Dis $\underline{63}, 1538-1543$

International Multiple Sclerosis Genetics Consortium (IMSGC), Wellcome Trust Case Control Consortium 2 (WTCCC2), International IBD Genetics Consortium (IIBDGC), Beecham AH, Patsopoulos NA, Xifara DK, Davis MF, Kemppinen A, Cotsapas C, Shah TS, et al. (2013): Analysis of immune-related loci identifies 48 new susceptibility variants for multiple sclerosis. Nat Genet $\underline{45}, 1353-1360$

Jayne D (2010): Role of rituximab therapy in glomerulonephritis: Table 1. J Am Soc Nephrol 21, $14-17$

Ji Q, Castelli L, Goverman JM (2013): MHC class I-restricted myelin epitopes are cross-presented by Tip-DCs that promote determinant spreading to CD8+ T cells. Nat Immunol 14, 254-261

Kabat EA, Freedman DA (1950): A study of the crystalline albumin, gamma globulin and total protein in the cerebrospinal fluid of 100 cases of multiple sclerosis and in other diseases. Am J Med Sci $219,55-64$

Kamburova EG, Koenen HJPM, Borgman KJE, ten Berge IJ, Joosten I, Hilbrands LB (2013): A single dose of rituximab does not deplete $\mathrm{B}$ cells in secondary lymphoid organs but alters phenotype and function: Rituximab alters B cells in human lymph nodes. Am J Transplant $\underline{13}, 1503-1511$

Kappos L, Hartung H-P, Freedman MS, Boyko A, Radü EW, Mikol DD, Lamarine M, Hyvert Y, Freudensprung U, Plitz T, van Beek J (2014): Atacicept in multiple sclerosis (ATAMS): A randomised, placebo-controlled, double-blind, phase 2 trial. Lancet Neurol $\underline{13}$, 353-363

Kawabe T, Naka T, Yoshida K, Tanaka T, Fujiwara H, Suematsu S, Yoshida N, Kishimoto T, Kikutani H (1994): The immune responses in CD40-deficient mice: Impaired immunoglobulin class switching and germinal center formation. Immunity $1,167-178$ 
Kebir H, Ifergan I, Alvarez JI, Bernard M, Poirier J, Arbour N, Duquette P, Prat A (2009): Preferential recruitment of interferon- $\gamma$-expressing TH17 cells in multiple sclerosis. Ann Neurol $\underline{66}$, $390-402$

Kim S-H, Kim W, Li XF, Jung I-J, Kim HJ (2011): Repeated treatment with rituximab based on the assessment of peripheral circulating memory $\mathrm{B}$ cells in patients with relapsing neuromyelitis optica over 2 years. Arch Neurol $\underline{68}, 1412-1420$

Kim S-H, Huh S-Y, Lee SJ, Joung A, Kim HJ (2013): A 5-year follow-up of rituximab treatment in patients with neuromyelitis optica spectrum disorder. JAMA Neurol $\underline{70}, 1110$

Kohn LA, Hao Q-L, Sasidharan R, Parekh C, Ge S, Zhu Y, Mikkola HKA, Crooks GM (2012): Lymphoid priming in human bone marrow begins prior to CD10 expression with up-regulation of L-selectin. Nat Immunol 13, 963-971

Kouwenhoven M, Teleshova N, Ozenci V, Press R, Link H (2001): Monocytes in multiple sclerosis: Phenotype and cytokine profile. J Neuroimmunol 112, 197-205

Kowarik MC, Cepok S, Sellner J, Grummel V, Weber MS, Korn T, Berthele A, Hemmer B (2012): CXCL13 is the major determinant for $\mathrm{B}$ cell recruitment to the CSF during neuroinflammation. J Neuroinflammation $\underline{9}, 93$

Kozovska ME, Hong J, Zang YCQ, Li S, Rivera VM, Killian JM, Zhang JZ (1999): Interferon beta induces T-helper 2 immune deviation in MS. Neurology $\underline{53}, 1692$

Krumbholz M, Theil D, Derfuss T, Rosenwald A, Schrader F, Monoranu C-M, Kalled SL, Hess DM, Serafini B, Aloisi F, et al. (2005): BAFF is produced by astrocytes and up-regulated in multiple sclerosis lesions and primary central nervous system lymphoma. J Exp Med 201, 195-200

Krumbholz M, Theil D, Cepok S, Hemmer B, Kivisäkk P, Ransohoff RM, Hofbauer M, Farina C, Derfuss T, Hartle C, et al. (2006): Chemokines in multiple sclerosis: CXCL12 and CXCL13 up-regulation is differentially linked to CNS immune cell recruitment. Brain 129, 200-211

Kuhlmann T, Lingfeld G, Bitsch A, Schuchardt J, Brück W (2002): Acute axonal damage in multiple sclerosis is most extensive in early disease stages and decreases over time. Brain $\underline{125}$, $2202-2212$

Kurtzke JF (1983): Rating neurologic impairment in multiple sclerosis: An expanded disability status scale (EDSS). Neurology $\underline{33}, 1444-1452$

Kverneland AH, Streitz M, Geissler E, Hutchinson J, Vogt K, Boës D, Niemann N, Pedersen AE, Schlickeiser S, Sawitzki B (2016): Age and gender leucocytes variances and references values generated using the standardized ONE-Study protocol: Age and gender leucocytes variances and references values using ONE-study protocol. Cytometry A $\underline{89}, 543-564$

Lang HLE, Jacobsen H, Ikemizu S, Andersson C, Harlos K, Madsen L, Hjorth P, Sondergaard L, Svejgaard A, Wucherpfennig K, et al. (2002): A functional and structural basis for TCR cross-reactivity in multiple sclerosis. Nat Immunol $\underline{3}, 940-943$

Lanzavecchia A (1985): Antigen-specific interaction between T and B cells. Nature $\underline{314}, 537-539$

Lassmann H, Raine CS, Antel J, Prineas JW (1998): Immunopathology of multiple sclerosis: Report on an international meeting held at the Institute of Neurology of the University of Vienna. J Neuroimmunol $\underline{86}, 213-217$

Leandro MJ (2013): B-cell subpopulations in humans and their differential susceptibility to depletion with anti-CD20 monoclonal antibodies. Arthritis Res Ther 15, S3 
Leandro MJ, Cambridge G, Ehrenstein MR, Edwards JCW (2006): Reconstitution of peripheral blood B cells after depletion with rituximab in patients with rheumatoid arthritis. Arthritis Rheum $\underline{54}$, 613-620

Lehmann-Horn K, Schleich E, Hertzenberg D, Hapfelmeier A, Kümpfel T, von Bubnoff N, Hohlfeld R, Berthele A, Hemmer B, Weber MS (2011): Anti-CD20 B-cell depletion enhances monocyte reactivity in neuroimmunological disorders. J Neuroinflammation $\underline{8}, 146$

Levin LI, Munger KL, O'Reilly EJ, Falk KI, Ascherio A (2010): Primary infection with the Epstein-Barr virus and risk of multiple sclerosis. Ann Neurol 67, 824-830

Liao W, Lin J-X, Leonard WJ (2011): IL-2 Family Cytokines: New insights into the complex roles of IL-2 as a broad regulator of T helper cell differentiation. Curr Opin Immunol 23, 598-604

Liu F, Bardhan K, Yang D, Thangaraju M, Ganapathy V, Waller JL, Liles GB, Lee JR, Liu K (2012): $\mathrm{NF}-x \mathrm{~B}$ directly regulates fas transcription to modulate Fas-mediated apoptosis and tumor suppression. J Biol Chem 287, 25530-25540

LL 312012 Diagnose und Therapie der Multiplen Sklerose. https:/ /www.dgn.org/leitlinien/2333-1l31-2012-diagnose-und-therapie-der-multiplen-sklerose\#therapie; Zugriff am 25.02.2019

Lublin FD, Reingold SC, National Multiple Sclerosis Society (USA) Advisory committee on clinical trials of new agents in multiple sclerosis* (1996): Defining the clinical course of multiple sclerosis: Results of an international survey. Neurology $\underline{46}$, 907-911

Lucchinetti C, Brück W, Parisi J, Scheithauer B, Rodriguez M, Lassmann H (2000): Heterogeneity of multiple sclerosis lesions: Implications for the pathogenesis of demyelination. Ann Neurol $\underline{47}, 707-717$

Lucchinetti CF, Brück W, Rodriguez M, Lassmann H (1996): Distinct patterns of multiple sclerosis pathology indicates heterogeneity on pathogenesis. Brain Pathol Zurich Switz $\underline{6}$, 259-274

Mahad DJ, Ziabreva I, Campbell G, Lax N, White K, Hanson PS, Lassmann H, Turnbull DM (2009): Mitochondrial changes within axons in multiple sclerosis. Brain J Neurol 132, 1161-1174

Mahnke YD, Brodie TM, Sallusto F, Roederer M, Lugli E (2013): The who's who of T-cell differentiation: Human memory T-cell subsets. Eur J Immunol 433, 2797-2809

Marrosu MG, Muntoni F, Murru MR, Costa G, Pischedda MP, Pirastu M, Sotgiu S, Rosati G, Cianchetti C (1992): HLA-DQB1 genotype in Sardinian multiple sclerosis: Evidence for a key role of DQB1 *0201 and *0302 alleles. Neurology 42, 883-886

Martin M del P, Cravens PD, Winger R, Kieseier BC, Cepok S, Eagar TN, Zamvil SS, Weber MS, Frohman EM, Kleinschmidt-Demasters BK, et al. (2009): Depletion of B lymphocytes from cerebral perivascular spaces by rituximab. Arch Neurol $\underline{66}$, 1016-1020

Martyn CN, Cruddas M, Compston DA (1993): Symptomatic Epstein-Barr virus infection and multiple sclerosis. J Neurol Neurosurg Psychiatry $\underline{56}, 167-168$

Maurer MA, Tuller F, Gredler V, Berger T, Lutterotti A, Lünemann JD, Reindl M (2016): Rituximab induces clonal expansion of $\operatorname{IgG}$ memory B-cells in patients with inflammatory central nervous system demyelination. J Neuroimmunol 290, 49-53

Melzer N, Meuth SG (2014): Disease-modifying therapy in multiple sclerosis and chronic inflammatory demyelinating polyradiculoneuropathy: Common and divergent current and future strategies. Clin Exp Immunol 175, 359-372 
Memon AB, Javed A, Caon C, Srivastawa S, Bao F, Bernitsas E, Chorostecki J, Tselis A, Seraji-Bozorgzad N, Khan O (2018): Long-term safety of rituximab induced peripheral B-cell depletion in autoimmune neurological diseases. PloS One $\underline{13}$, e0190425

Mikaeloff Y, Caridade G, Tardieu M, Suissa S, on behalf of the KIDSEP study group (2007): Parental smoking at home and the risk of childhood-onset multiple sclerosis in children. Brain $\underline{130}$, 2589-2595

Miron VE, Boyd A, Zhao J-W, Yuen TJ, Ruckh JM, Shadrach JL, van Wijngaarden P, Wagers AJ, Williams A, Franklin RJM, ffrench-Constant C (2013): M2 microglia/macrophages drive oligodendrocyte differentiation during CNS remyelination. Nat Neurosci $\underline{16}, 1211-1218$

Molnarfi N, Schulze-Topphoff U, Weber MS, Patarroyo JC, Prod'homme T, Varrin-Doyer M, Shetty A, Linington C, Slavin AJ, Hidalgo J, et al. (2013): MHC class II-dependent B cell APC function is required for induction of CNS autoimmunity independent of myelin-specific antibodies. J Exp Med 210, 2921-2937

Moore KW, de Waal Malefyt R, Coffman RL, O'Garra A (2001): Interleukin-10 and the interleukin-10 receptor. Annu Rev Immunol 19, 683-765

Morbach H, Eichhorn EM, Liese JG, Girschick HJ (2010): Reference values for B cell subpopulations from infancy to adulthood. Clin Exp Immunol 162, 271-279

Mosser DM, Zhang X (2008): Interleukin-10: new perspectives on an old cytokine. Immunol Rev $\underline{226}, 205-218$

Mundt S, Mrdjen D, Utz SG, Greter M, Schreiner B, Becher B (2019): Conventional DCs sample and present myelin antigens in the healthy CNS and allow parenchymal T cell entry to initiate neuroinflammation. Sci Immunol $\underline{4}$, eaau8380

Münz C, Lünemann JD, Getts MT, Miller SD (2009): Antiviral immune responses: Triggers of or triggered by autoimmunity? Nat Rev Immunol $\underline{9}, 246-258$

Niedel JE, Kuhn LJ, Vandenbark GR (1983): Phorbol diester receptor copurifies with protein kinase C. Proc Natl Acad Sci U S A $\underline{80}, 36-40$

Obermeier B, Mentele R, Malotka J, Kellermann J, Kümpfel T, Wekerle H, Lottspeich F, Hohlfeld R, Dornmair K (2008): Matching of oligoclonal immunoglobulin transcriptomes and proteomes of cerebrospinal fluid in multiple sclerosis. Nat Med 14, 688

Olerup O, Hillert J (1991): HLA class II-associated genetic susceptibility in multiple sclerosis: a critical evaluation. Tissue Antigens $\underline{38}, 1-15$

Owen JA, Punt Jenni, Stranford SA, Jones PP, Kuby Janis: Kuby immunology. W.H. Freeman, New York 2013

Pers J-O, Daridon C, Bendaoud B, Devauchelle V, Berthou C, Saraux A, Youinou P (2007): B-Cell depletion and repopulation in autoimmune diseases. Clin Rev Allergy Amp Immunol $\underline{34}$, 50-55

Qin Y, Duquette P, Zhang Y, Talbot P, Poole R, Antel J (1998): Clonal expansion and somatic hypermutation of $\mathrm{V}(\mathrm{H})$ genes of $\mathrm{B}$ cells from cerebrospinal fluid in multiple sclerosis. J Clin Invest 102, 1045-1050

Quintana FJ, Patel B, Yeste A, Nyirenda M, Kenison J, Rahbari R, Fetco D, Hussain M, O’Mahony J, Magalhaes S, et al. (2014): Epitope spreading as an early pathogenic event in pediatric multiple sclerosis. Neurology $\underline{83}, 2219-2226$ 
Ramagopalan SV, Morris AP, Dyment DA, Herrera BM, DeLuca GC, Lincoln MR, Orton SM, Chao MJ, Sadovnick AD, Ebers GC (2007): The inheritance of resistance alleles in multiple sclerosis. PLoS Genet $\underline{3}, 1607-1613$

Ramirez-Ortiz ZG, Specht CA, Wang JP, Lee CK, Bartholomeu DC, Gazzinelli RT, Levitz SM (2008): Toll-Like Receptor 9-dependent immune activation by unmethylated CpG motifs in aspergillus fumigatus DNA. Infect Immun $\underline{76}, 2123-2129$

Ransohoff RM, Engelhardt B (2012): The anatomical and cellular basis of immune surveillance in the central nervous system. Nat Rev Immunol 12, 623-635

Reff ME, Carner K, Chambers KS, Chinn PC, Leonard JE, Raab R, Newman RA, Hanna N, Anderson DR (1994): Depletion of B cells in vivo by a chimeric mouse human monoclonal antibody to CD20. Blood 83 , 435-445

Roll P, Palanichamy A, Kneitz C, Dorner T, Tony H-P (2006): Regeneration of B cell subsets after transient B cell depletion using anti-CD20 antibodies in rheumatoid arthritis. Arthritis Rheum 54, 2377-2386

Rothfield L, Pearlman-Kothencz M (1969): Synthesis and assembly of bacterial membrane components. A lipopolysaccharide-phospholipid-protein complex excreted by living bacteria. J Mol Biol 44, 477-492

Rubtsova K, Marrack P, Rubtsov AV (2012): Age-associated B cells: Are they the key to understanding why autoimmune diseases are more prevalent in women? Expert Rev Clin Immunol $\underline{8}, 5-7$

Sakaguchi S, Sakaguchi N, Asano M, Itoh M, Toda M (1995): Immunologic self-tolerance maintained by activated T cells expressing IL-2 receptor alpha-chains (CD25). Breakdown of a single mechanism of self-tolerance causes various autoimmune diseases. J Immunol Baltim Md $1950 \underline{155}, 1151-1164$

Sallusto F, Geginat J, Lanzavecchia A (2004): Central memory and effector memory T cell subsets: Function, generation, and maintenance. Annu Rev Immunol 22, 745-763

Sathaliyawala T, Kubota M, Yudanin N, Turner D, Camp P, Thome JJC, Bickham KL, Lerner H, Goldstein M, Sykes M, et al. (2013): Distribution and compartmentalization of human circulating and tissue-resident memory T cell subsets. Immunity $\underline{38}, 187-197$

Sawcer S, Franklin RJM, Ban M (2014): Multiple sclerosis genetics. Lancet Neurol 13, 700-709

Schneider P (2005): The role of APRIL and BAFF in lymphocyte activation. Curr Opin Immunol $\underline{17}$, 282-289

Schuh E, Berer K, Mulazzani M, Feil K, Meinl I, Lahm H, Krane M, Lange R, Pfannes K, Subklewe M, et al. (2016): Features of human CD3+CD20+ T cells. J Immunol $\underline{197}, 1111-1117$

Serafini B, Rosicarelli B, Magliozzi R, Stigliano E, Aloisi F (2004): Detection of ectopic B-cell follicles with germinal centers in the meninges of patients with secondary progressive multiple sclerosis. Brain Pathol 14, 164-174

Sorensen PS, Blinkenberg M (2016): The potential role for ocrelizumab in the treatment of multiple sclerosis: current evidence and future prospects. Ther Adv Neurol Disord 9, 44-52

Souto-Carneiro MM, Mahadevan V, Takada K, Fritsch-Stork R, Nanki T, Brown M, Fleisher TA, Wilson M, Goldbach-Mansky R, Lipsky PE (2009): Alterations in peripheral blood memory $\mathrm{B}$ cells in patients with active rheumatoid arthritis are dependent on the action of tumour necrosis factor. Arthritis Res Ther 11, R84 
Storie I, Wilson GA, Granger V, Barnett D, Reilly JT (1995): Circulating CD20dim T-lymphocytes increase with age: Evidence for a memory cytotoxic phenotype. Clin Lab Haematol 17, $323-328$

Surh CD, Sprent J (2008): Homeostasis of naive and memory T cells. Immunity $\underline{29}$, 848-862

Svenningsson A, Bergman J, Dring A, Vågberg M, Birgander R, Lindqvist T, Gilthorpe J, Bergenheim $T$ (2015): Rapid depletion of B lymphocytes by ultra-low-dose rituximab delivered intrathecally. Neurol Neuroimmunol Neuroinflammation 2 , e79

Theil D, Farina C, Meinl E (2005): Differential expression of CD150 (SLAM) on monocytes and macrophages in chronic inflammatory contexts: abundant in Crohn's disease, but not in multiple sclerosis. J Clin Pathol $\underline{58}, 110-111$

Thompson AJ, Banwell BL, Barkhof F, Carroll WM, Coetzee T, Comi G, Correale J, Fazekas F, Filippi M, Freedman MS, et al. (2018): Diagnosis of multiple sclerosis: 2017 revisions of the McDonald criteria. Lancet Neurol 17, 162-173

Titelbaum DS, Degenhardt A, Kinkel RP (2005): Anti-tumor necrosis factor alpha-associated multiple sclerosis. AJNR Am J Neuroradiol 26, 1548-1550

Trapp BD, Peterson J, Ransohoff RM, Rudick R, Mörk S, Bö L (1998): Axonal Transection in the Lesions of Multiple Sclerosis. N Engl J Med $\underline{338}, 278-285$

Underhill DM, Ozinsky A (2002): Toll-like receptors: Key mediators of microbe detection. Curr Opin Immunol 14, 103-110

Vieira PL, Heystek HC, Wormmeester J, Wierenga EA, Kapsenberg ML (2003): Glatiramer acetate (Copolymer-1, Copaxone) promotes Th2 cell development and increased IL-10 production through modulation of dendritic cells. J Immunol 170, 4483-4488

von Essen MR, Ammitzbøll C, Hansen RH, Petersen ERS, McWilliam O, Marquart HV, Damm P, Sellebjerg F (2019): Proinflammatory CD20+ T cells in the pathogenesis of multiple sclerosis. Brain $\underline{142}, 120-132$

Wajant H (2002): The Fas signaling pathway: More than a paradigm. Science 296, 1635

Weber MS, Hemmer B, Cepok S (2011): The role of antibodies in multiple sclerosis. Biochim Biophys Acta BBA - Mol Basis Dis 1812, 239-245

Weinshenker BG, Bass B, Rice GP, Noseworthy J, Carriere W, Baskerville J, Ebers GC (1989): The natural history of multiple sclerosis: a geographically based study. I. Clinical course and disability. Brain J Neurol 112 (Pt 1), 133-146

Wucherpfennig KW, Sethi D (2011): T cell receptor recognition of self and foreign antigens in the induction of autoimmunity. Semin Immunol 23, 84-91

Ziegler SF, Ramsdell F, Alderson MR (1994): The activation antigen CD69. Stem Cells Dayt Ohio $\underline{12}, 456-465$

Zoghi S, Amirghofran Z, Nikseresht A, Ashjazadeh N, Kamali-Sarvestani E, Rezaei N (2011): Cytokine secretion pattern in treatment of lymphocytes of multiple sclerosis patients with fumaric acid esters. Immunol Invest 40, 581-596 


\section{Acknowledgments}

Firstly, I would like to thank Martin Weber, my supervisor, who gave me the opportunity to work in his reasurch group. I am greatful for all his guidness, scientific expertise, personal teaching, help and support. With his help I have learned to develop my own ideas and theories.

I thank Fred Lühder for his help and constructive critisisem during my prograss report meetings and after. I especially thank him for not accepting nothing but perfect.

I thank the members of the Weber reasearch group for their help and advice. I specially wish to thank Katja Grondey and Jan Traub who instructed and assisted me in both methods and experiments, and Sebastian Torke, whos advices helped me with my paper. Furthermore I wish to thank Jasmin Ochs and Julian Koch for their assistance.

Further I wish to thank Silke Häusser-Kinzel, whos advices helped me to better agument my theories and hypotheses.

I wish to thank Cynthia Bunker, Heidi Berns and Bernd Zirk for their support.

I thank the Gerhard C. Stark Stiftung for their support and endorsement.

I thank my parents, who always encourenged and helped me to achieve my dreams.

This work is dedicated to Wolfgang Brück, without whom nothing is possible, and with whom everything is. 


\section{Curriculum vitae}

For data protection reasons I wish not to publish my résumé in the electronic version of my work. 